\title{
41. APPLICATIONS FOR WHOLE-CORE MAGNETIC SUSCEPTIBILITY MEASUREMENTS OF DEEP-SEA SEDIMENTS: LEG 115 RESULTS ${ }^{1}$
}

\author{
Simon G. Robinson ${ }^{2}$
}

\begin{abstract}
Whole-core (WC) measurements of low-field magnetic susceptibility (MS) provide an extremely simple, rapid, and nondestructive technique for high-resolution core logging and lithostratigraphic correlation between subsidiary holes at Ocean Drilling Program (ODP) sites. This is particularly useful for reconstructing composite, stratigraphically continuous sequences for individual ODP sites by splicing the uninterrupted records obtained from subsections of offset cores recovered from adjacent holes. Correlation between the WCMS profiles of holes drilled at different sites is also possible in some instances, especially when lithologic variations at each site are controlled by regional paleoceanographic or global (i.e., orbitally forced) paleoclimatic changes. In such circumstances, WCMS may also be used as a proxy paleoclimatic indicator, duly assisting climatostratigraphic zonation of the recovered sequence by more conventional microfossil and isotopic techniques.

High-resolution WCMS profiles are also useful in detecting intervals of the recovered sequence affected by drilling disturbance, in the form of contamination by pipe rust or similar metallic artifacts as well as discontinuities related to repenetration of the corer or loss of material between successively cored intervals.

Stratigraphic intervals that have been affected by early (suboxic) diagenesis resulting from a high initial organic matter content of the sediment are also readily identified by WCMS logging. The MS signal of horizons affected by suboxic diagensis is typically degraded in proportion to the duration and intensity (related to initial $\mathrm{C}_{\text {org }}$ concentration) of organic matter remineralization. The lowering of MS values during suboxic diagenesis results from "dissolution" (bacterially mediated ionic dissociation) of magnetic iron and manganese oxides and oxyhydroxides in the sediment.

It is to be hoped that, on future ODP (or similar) cruises, WCMS logging will cease to be regarded as a mere adjunct to paleomagnetic measurements, but rather as a simple, yet powerful, lithostratigraphic tool, directly analogous to downhole geophysical logging tools, and complimentary to shipboard techniques for whole-core measurements of physical properties (e.g., $P$-wave logging, GRAPE, etc.).
\end{abstract}

\section{INTRODUCTION}

The aim of the following study is to demonstrate various applications for whole-core magnetic susceptibility (WCMS) data routinely gathered during Ocean Drilling Program (ODP) or similar deep-sea sediment coring expeditions, using the results of WCMS measurements made during ODP Leg 115 (Fig. 1) to illustrate the account. The objective of this demonstration is to indicate possible ways in which this simple and nondestructive technique can be used to assist the work of shipboard sedimentologists and stratigraphers by providing, in effect, a method for quantitative lithostratigraphy.

Initial reports of the potential value of WCMS logging in lithostratigraphic studies of deep-sea sediments were published by Radhakrishnamurty et al. (1968), Amin et al. (1972), and Somayajulu et al. $(1974,1975)$. At the same time, some paleolimnologists were already using WCMS logging for multiple correlation of lake sediment cores (e.g., Thompson, 1973; Thompson et al., 1975; Oldfield et al., 1978; Thompson and Morton, 1979), based on a technique for WCMS scanning of wet sediments described by Molyneux and Thompson (1973).

The WCMS logs recorded in these early studies, however, were comparatively crude in relation to the high-resolution, high signal-to-noise ratio profiles obtained using the Bartington MS system that have generally been used for core correlation in more recent studies-both of lake sediments (e.g., Bloemendal et al., 1979; Bloemendal, 1982; Dearing et al., 1981; Dearing,

\footnotetext{
${ }^{1}$ Duncan, R. A., Backman, J., Peterson, L. C., et al., 1990. Proc. ODP, Sci. Results, 115: College Station, TX (Ocean Drilling Program).

2 Subdepartment of Quaternary Research, University of Cambridge, Godwin Laboratory, Free School Lane, Cambridge CB2 3RS, United Kingdom.
}

1983; Thompson and Oldfield, 1986, p. 144), and of deep-sea sediments (e.g., Robinson, 1982, 1986a, 1986b; Robinson and Bloemendal, 1983; Thompson and Oldfield, 1986, p. 144), including recent Proceedings of the Ocean Drilling Program, Initial Reports (e.g., Srivastava, Arthur, Clement, et al., 1987; Ruddiman, Sarnthein, Baldauf, et al., 1988; Mascle, Moore, et al., 1988; Ciesielski, Kristoffersen, et al., 1988; Backman, Duncan, et al., 1988; Prell, Niitsuma, et al., 1989).

\section{Magnetic Susceptibility: Definition and Interpretation}

Magnetic susceptibility literally means the ease with which a substance can be magnetized, that is, the extent to which it is attracted to or repelled by a magnetic field. Low-field volume magnetic susceptibility $(K)$ is defined as the ratio of induced magnetization intensity $(M)$ per unit volume of a substance to the strength of the applied magnetic field $(H)$ inducing the magnetization (i.e., $K=M / H$; Thompson and Oldfield, 1986, p. 25). In low magnetic fields (e.g., $<1 \mathrm{Oe}$ ), $M$ is generally thought to vary linearly with $H$, although this assumption has recently been challenged (see Smith and Banerjee, 1987); thus, the magnetic moment induced in the substance, when subjected to the weak magnetic field, reverts to zero on removal of the applied field (Collinson, 1983, p. 14). Magnetic susceptibility, therefore, is not a measure of a permanent (remanent) magnetization (RM) retained by the sample on removal of an applied magnetic field, either natural (NRM) or artificial (e.g., isothermal or anhysteretic remanence [IRM, ARM]). Hence, magnetic susceptibility is totally unrelated to the Earth's magnetic field, past or present.

Because $M$ and $H$ are measured in units of magnetic field, $K$ is a dimensionless ratio. That is, magnetic susceptibility is effectively a measure of the change in the strength of a magnetic field (positive or negative) caused by placing a sample into that 


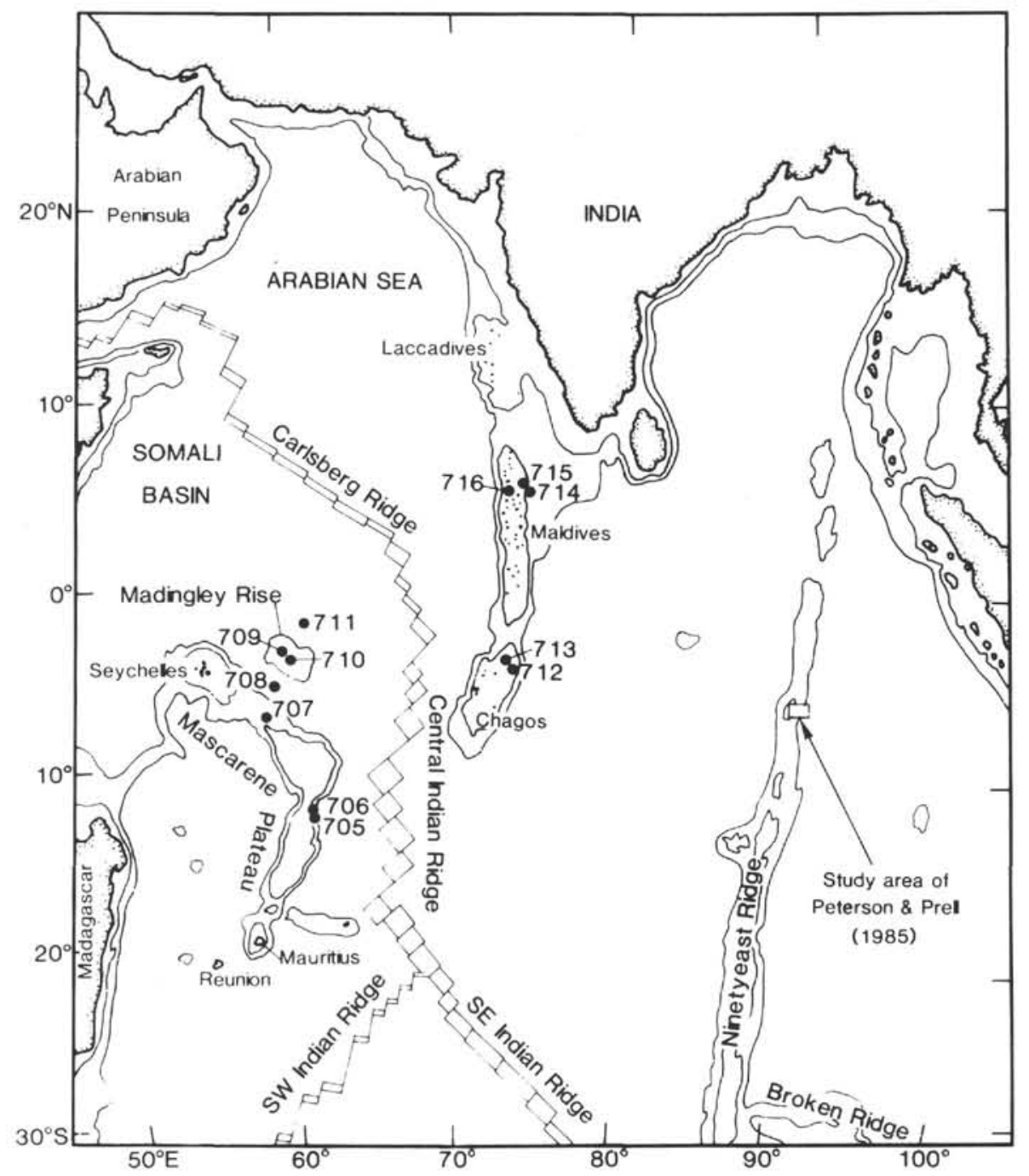

Figure 1. Locations of Leg 115 drilling sites referred to in this study.

field. The response of a sample to a magnetic field, or vice versa, is entirely a function of the concentration and composition (i.e., mineralogy and grain size) of magnetizable material that the sample contains (Thompson and Oldfield, 1986, p. 25). The volume magnetic susceptibilities of natural materials like deep-sea sediments are largely a function of the concentrations (per unit volume) of magnetizable material that they contain. Magnetizable, as distinct from magnetic, constituents of deepsea sediments not only include the ferromagnetic (ferrimagnetic and canted-antiferromagnetic) minerals that may acquire remanent magnetization (NRM, IRM, ARM, etc.), but also any compound that contains $\mathrm{Fe}^{2+}, \mathrm{Fe}^{3+}$, or $\mathrm{Mn}^{2+}$ ions. These so-called paramagnetic substances include clay minerals, particularly chlorite and smectite; ferromagnesian silicate minerals, including olivines, pyroxenes, biotite, and garnet; iron and manganese carbonates like siderite, ankerite, and rhodocrosite; some iron sulfides like pyrite and gregite; and authigenic, often colloidal, ferric oxyhydroxide complexes (e.g., mixtures of feroxyhyte, ferrihydrite, lepidocrocite, akaganeite, etc.), collectively referred to as limonite, that frequently occur in the pore waters of deep-sea sediments (Burns and Burns, 1981).

The most common remanence-carrying minerals found in deep-sea sediments-their origins, mineralogy, geochemical stability, and magnetic properties - are reviewed by Murray (1979), Lowrie and Heller (1982), Oldfield and Robinson (1985), Free- man (1986), and Robinson (1986b). These include (1) ferrimagnetic iron-titanium oxides like (titano)magnetite and (titano) maghemite, characterized by extremely high, but grain-size-dependent MS values (i.e., between $10^{-3}$ and $10^{-1} \mathrm{cgs}$ ), which usually mask all other contributions to bulk sediment MS when these minerals are present in concentrations of more than one or two parts per thousand (Thompson and Oldfield, 1986, p. 28); (2) canted-antiferromagnetic iron oxides like (titano)hematite, and iron oxyhydroxides like goethite, which exhibit much lower MS values (i.e., between $10^{-7}$ and $10^{-5} \mathrm{cgs}$ ); and (3) iron sulfides belonging to the pyrrhotite series, which also exhibit ferrimagnetic behavior and are thus characterized by high MS values (i.e., between $10^{-6}$ and $10^{-3} \mathrm{cgs}$ ). Other strongly magnetic components of deep-sea sediments may occur in authigenic Fe-Mn oxyhydroxide phases, usually in the form of nodules, micronodules, and encrustations (e.g., see Burns and Burns, 1981, and references therein; Nesteroff, 1982). Among these, the most notable manganese-bearing magnetic minerals are jacobsite (ferrimagnetic) and todorokite (possibly ferrimagnetic) (Henshaw and Merrill, 1980).

In contrast to the strongly magnetizable (ferromagnetic and paramagnetic) components of deep-sea sediments that occur mainly in the lithogenic fraction of the sediment, biogenic carbonate and silica are not only very weakly magnetizable, but actually exhibit diamagnetic behavior, that is, they are character- 
ized by negative MS values (usually between -1 and $-5 \times 10^{-7}$ cgs). Downcore variations in the MS values of deep-sea sediments, therefore, tend to reflect changes in lithology, that is, fluctuations in the ratio of biogenic to lithogenic components in the sediment, which is essentially the basis for lithologic classification of deep-sea sediments (e.g., see Backman, Duncan, et al., 1988, p. 22). Exceptions to this relationship include diamagnetic components of lithogenic origin like detrital quartz and alkali feldspar, and ferromagnetic minerals of biogenic origin like bacterial magnetite (e.g., Petersen et al., 1986; Chang and Kirschvink, 1987; Karlin et al., 1987) and Chiton teeth magnetite (e.g., Kirschvink and Lowenstam, 1979).

It is important to note that variations in the MS of deep-sea sediments reflect the proportion of biogenic (carbonate and silica) to lithogenic (clay and labile mineral) components in the sequence, as distinct from the carbonate/noncarbonate ratio. Accordingly, when WCMS profiles do not reflect downcore variations in the carbonate content of deep-sea sediments, it is probable that biogenic silica constitutes a significant fraction of the sediment. Important exceptions to this generalization include (1) the disproportionately high MS values associated with volcanic-ash-rich sediments (e.g., Oldfield et al., 1978); (2) organic-rich sediments affected by suboxic diagenesis, which often leads to the dissolution of magnetic minerals (Karlin and Levi, 1983, 1985; Canfield and Berner, 1987); and (3) significant downcore variations in the provenance and/or accumulation rate of detrital magnetic material that are unrelated to paleoceanographic factors controlling the relative accumulation rates of the biogenic and lithogenic fractions of the sediment (e.g., tectonically induced changes in sediment source and flux density).

\section{METHODS}

\section{Whole-core Magnetic Susceptibility}

On board the JOIDES Resolution, measurements of WCMS are made with a Bartington Instruments' MS system, which is based on a modification of the principle used by metal detectors (Lancaster, 1966). A magnetic field is created by passing an alternating-frequency current (AC) through a coil that forms a loop with an 80 -mm inner diameter, through which whole-core sections are passed. Unlike direct AC methods of MS measurement (see Collinson, 1983, p. 21), however, the Bartington system does not detect the change in magnetic field caused by placing a sample into the field. Instead, the Bartington system measures, by means of a sharply tuned oscillator circuit, variations in the frequency of the $\mathrm{AC}$ waveform that result from passing the core through the loop. The change in AC frequency is directly proportional to the MS of the sample.

The system is calibrated using a range of paramagnetic salts (e.g., copper sulfate, ferrous sulfate) and, at the lower end of the scale, distilled water as standards, yielding a noise level on the order of $\sim 5 \times 10^{-8} \mathrm{cgs}$, and a measuring range from 1 to $9999 \times 10^{-6} \mathrm{cgs}$. The system operates with an AC field of $1 \mathrm{Oe}$ and in two frequency modes, 0.47 and $4.7 \mathrm{kHz}$, to aid in measuring "frequency-dependent" MS (Collinson, 1983, p. 33; Thompson and Oldfield, 1986, p. 55) for whole cores and single samples. Measurements of frequency-dependent MS were attempted during Leg 115, but the results proved to be unreliable because of the ship's movements, external sources of electrical interference, and difficulties in reorienting core sections accurately between low-frequency and high-frequency measurement cycles.

On Leg 115, WCMS measurements involved manually passing whole-core sections through an $80-\mathrm{mm}$, loop-type sensor and recording changes in MS at successive intervals downsection by means of the shipboard "work-station" microcomputer, to which the MS system was interfaced. Measurements were made at intervals of $3,5,6,7$, or $10 \mathrm{~cm}$, depending on the rate of re- covery, degree of disturbance, and/or lithologic homogeneity of the cores measured. The WCMS system on board JOIDES Resolution now also incorporates an automated "tow-through" facility and is considerably more efficient.

\section{Carbonate Content}

Carbonate content data shown in Figure 2 are from measurements made post cruise on samples taken at $5-\mathrm{cm}$ intervals from Core $115-711 \mathrm{~A}-1 \mathrm{H}$. Bulk carbonate content determinations were made using the Chittick gasometric apparatus (Dreimanis, 1962), based on the method outlined by Bascomb (1974). The results obtained by this procedure were reproducible to within a range equivalent to $0.5 \%-1.0 \% \mathrm{CaCO}_{3}$. All other calcimetric data presented in this study were obtained on board ship.

\section{APPLICATIONS (AND LEG 115 RESULTS)}

In this section, the results of WCMS (and carbonate content) measurements made during Leg 115 (and other) sediments are presented thematically; they are arranged according to the various applications envisaged for this kind of data. Since several of these applications are interrelated, data presented in any one figure, below, may be relevant to more than one application and, thus, may be referred to in more than one of the following sections.

\section{Core Logging}

As noted above, the WCMS profiles of deep-sea sediment cores frequently reflect changes in lithology, that is, variations in the ratio of biogenic to lithogenic components in the sediment (except for tephra-rich or anoxic/suboxic sediments). Wholecore MS logging of deep-sea sediments has been previously used, therefore, mainly as a tool for local or regional scale lithostratigraphic corelation of cores (see "Introduction," this chapter). There are, however, several situations in which WCMS logging of deep-sea sediments may provide valuable sedimentologic (and sometimes paleoclimatic) information per se, regardless of its implications for correlation purposes. The following examples demonstrate several aspects of this application for WCMS data and illustrate the relationship between core lithology and MS at various scales of measurement.

In Figure 3, the WCMS profiles of three subsections of Hole $708 \mathrm{~A}$ are plotted alongside logs of calc-turbidites in the sequence taken from shipboard, visual core description data. Calcturbidite horizons clearly correlate with major negative deflections in the WCMS profiles of this hole, and are also characterized by generally low but erratic MS values (except for turbidites with gradational tops), reflecting the unstructured nature of these deposits. Precise identification of the true thickness and character of calc-turbidite horizons in the sequence, by means of WCMS logging, considerably helped the task of estimating the rate of pelagic sediment accumulation at this site, and thus improves the accuracy of stratigraphic sections, age/depth plots, and so forth, by enabling these to be expressed on a turbiditefree basis (e.g., Backman, Duncan, et al., 1988, p. 401).

Hole 708A was drilled at a depth of 4109 mbsl (Fig. 1), which lies close to the present-day carbonate compensation depth (CCD) for the Indian Ocean (Kolla et al., 1976; Sclater et al., 1977; Peterson and Prell, 1985a). Accordingly, variations in MS between calc-turbidite horizons in Hole 708A (Fig. 3) reflect changes in the carbonate content of the sediment (and thus lithology) that may be related to the effects of dissolution caused by CCD fluctuations. Variations in the regional CCD may possibly be related to climatic changes during the Pleistocene (Fig. 3 , left), but the generally higher turbidite-free MS values exhibited by the early and middle Miocene sections of Hole 708A (Fig. 3, right and center; see also Fig. 15) suggest that a much more pronounced shoaling of the CCD occurred in the equato- 


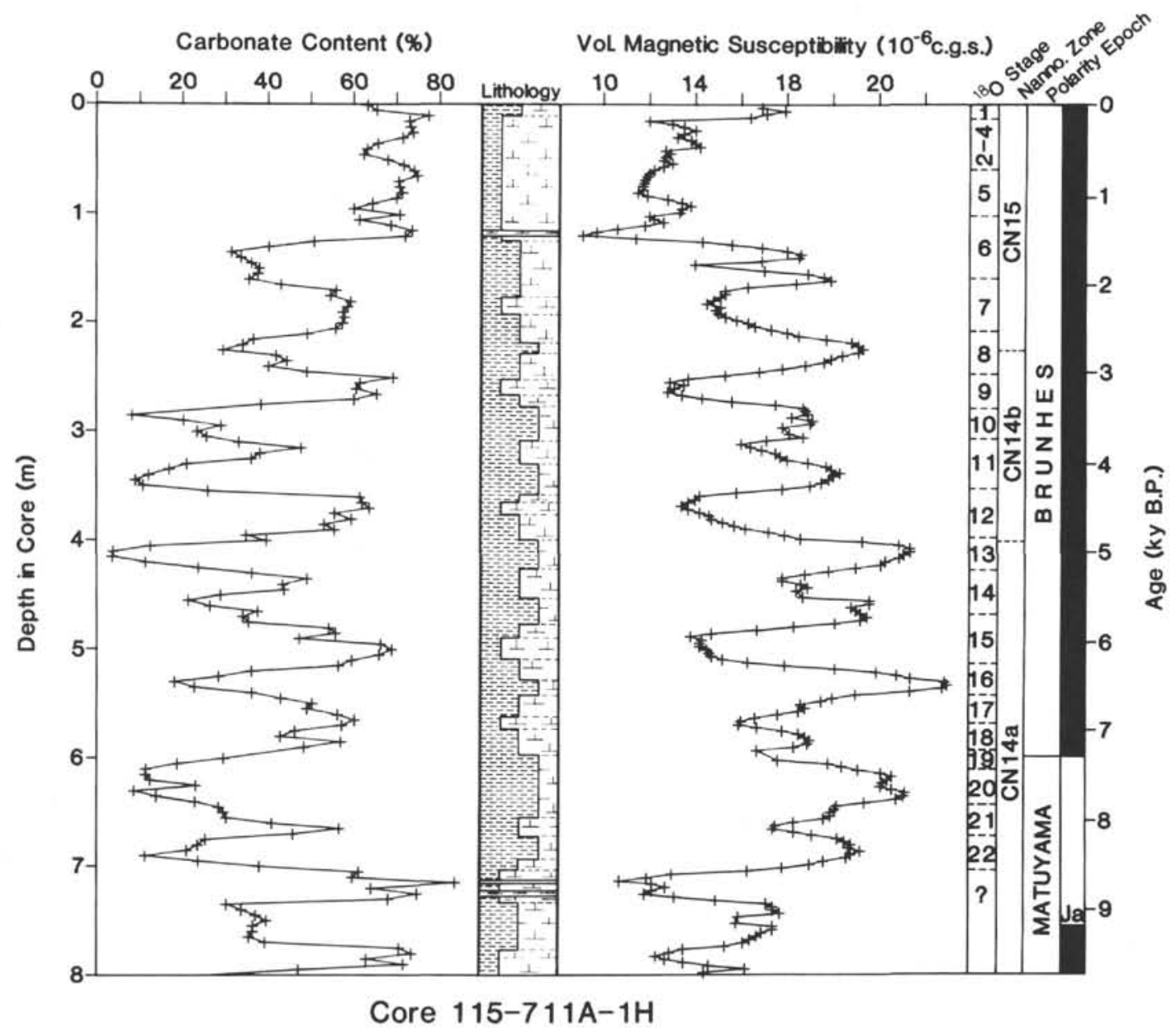

Figure 2. WCMS and \%-carbonate profiles of Core 115-711A-1H, plotted alongside a log of core lithology taken from "barrel sheet" core description data. The positions of hypothetical oxygen-isotope stage boundaries are based on the shipboard paleomagnetic and biostratigraphic time scale for this core (shown right), using the ages for these events given by Imbrie et al. (1984). The \%-carbonate profile is based on measurements made for the present study on samples taken at $5-\mathrm{cm}$ intervals.

rial Indian Ocean during this period. This interpretation is consistent with previous reports of increased dissolution of early and middle Miocene deep-sea sediments in the Indian Ocean (e.g., van Andel, 1975). The relationship between variations in lithology and WCMS for turbidite-free pelagic sediments similar to those deposited at Site 708 is more clearly illustrated in Figure 2.

Figure 2 shows the WCMS (3-cm interval) and carbonate content $(5-\mathrm{cm}$ interval) profiles of Core $115-711 \mathrm{~A}-1 \mathrm{H}$, plotted alongside the lithologic log of this core taken directly from shipboard core description data (Backman, Duncan, et al., 1988, p. 697). Also shown in Figure 2 are the paleomagnetic and nannofossil stratigraphies for this core, from which the time scale, shown on the right, is derived, and upon which the assumed positions of oxygen isotope stages are interpolated. Site 711 lies at a depth of $4428 \mathrm{mbsl}$, making it the deepest site drilled during Leg 115. This site constitutes the deep end-member of the Leg 115 "carbonate dissolution profile" (CDP), which comprises a series of closely spaced sites drilled along a bathymetric transect of the Madingley Rise (Fig. 1), for the purpose of studying the variation in pelagic carbonate accumulation rates, as a function of water depth, in the tropical Indian Ocean (Backman, Duncan, et al., 1988, p. 9).

With the exception of three microturbidite horizons, $5-7 \mathrm{~cm}$ in thickness, variations in the lithology of Core $115-711 \mathrm{~A}-1 \mathrm{H}$ are all related to the effects of carbonate dissolution (Backman, Duncan, et al., 1988, p. 664), probably to fluctuations in the regional CCD during the Pleistocene (cf. Peterson and Prell, 1985b). Regular oscillations in biogenic carbonate accumulation (almost exclusively nannofossils), superimposed on a relatively constant rate of lithogenic clay input, have effected an apparently "interbedded" sequence at this site, comprising alternating horizons of clayey-nannofossil ooze $\left(60 \%-85 \% \mathrm{CaCO}_{3}\right)$, radiolarian-bearing nannofossil clay $\left(30 \%-60 \% \mathrm{CaCO}_{3}\right)$, and nannofossil-bearing clay $\left(<30 \% \mathrm{CaCO}_{3}\right.$, with a minimum of $<5 \%$ $\mathrm{CaCO}_{3}$ at around $4 \mathrm{~m}$ depth in core).

The sequence of regularly spaced, dissolution-controlled cycles in the carbonate content of Core $115-711 \mathrm{~A}-1 \mathrm{H}$ are clearly mirrored by its WCMS profile (Fig. 3). Peaks in the WCMS profile of this core correspond to clay-rich intervals, whereas troughs correspond to carbonate-rich intervals-both in direct proportion to the carbonate content of the sediment. The correlation coefficient (Pearson's $r$ ) for the relationship between carbonate content and MS for this core is $0.971\left(\mathrm{p}^{\prime}=99.9 \%, N\right.$ $=159$ ). The paleoclimatic implications of this relationship are considered below (see "Paleoclimatic Investigations" section, this chapter).

On a much larger scale, Figure 4 shows the relationship among the WCMS data, carbonate content (shipboard data) measurements, and lithologic units for the entire sequence re- 

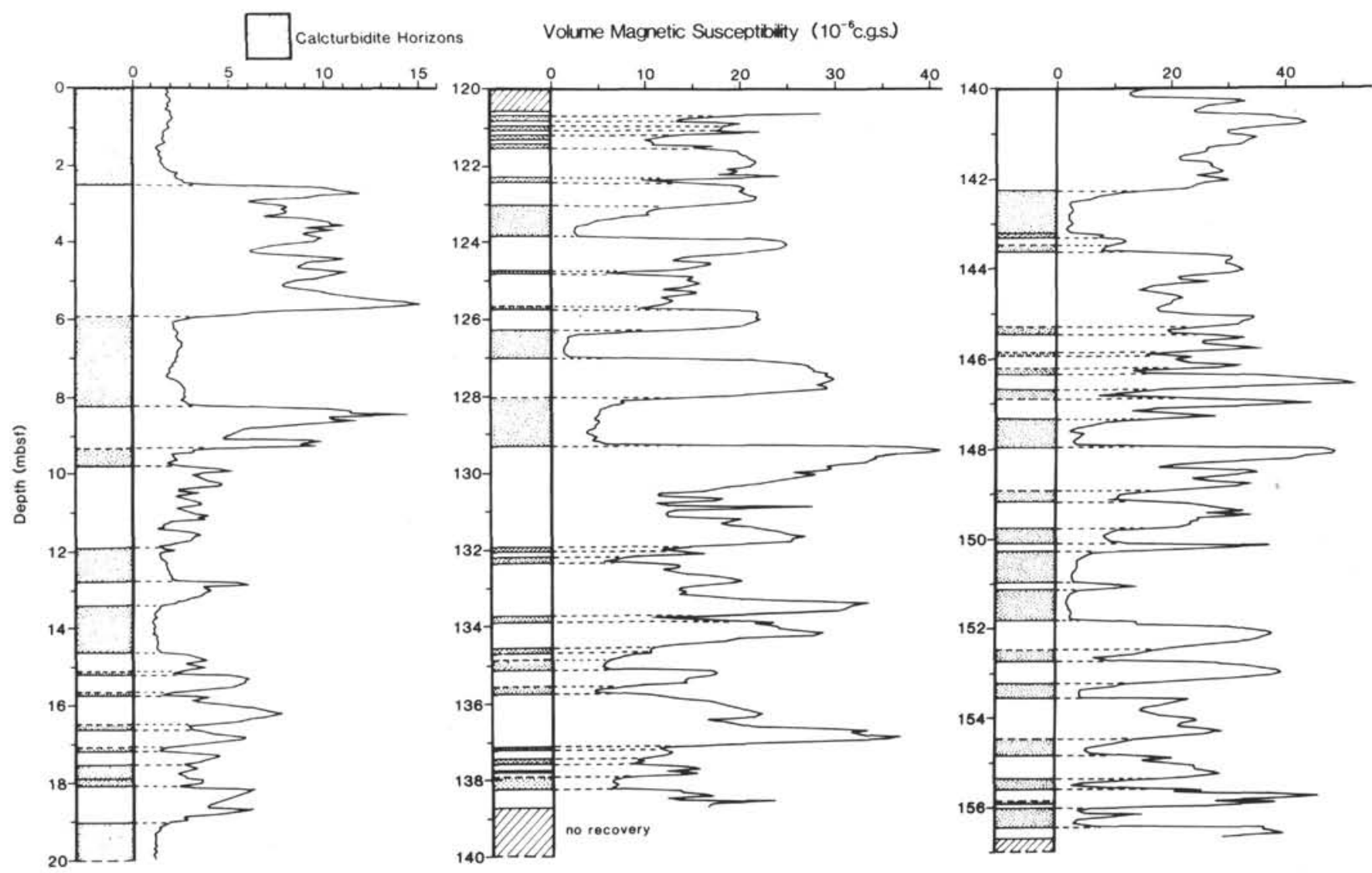

Figure 3. WCMS profiles of three intervals of Hole 708A, plotted alongside logs of calcturbidite horizons in the sequence (stippled intervals) taken from visual core description data. Left, Quaternary interval (Cores 115-708A-1H and -2H); center, middle and late Miocene interval (Cores 115-708A$14 \mathrm{X}$ and $-15 \mathrm{X}$ ); and right, early and middle miocene interval (Cores 115-708A-16X and -17X).

covered from Hole 710A. Site 710 lies at a depth of $3812 \mathrm{mbsl}$ (Fig. 1), which is close to the present-day sedimentary lysocline in the northwest Indian Ocean (Peterson and Prell, 1985a), but significantly shallower than Sites 708 and 711. Dissolution of carbonate constituents in the sediment at Site 710, therefore, is rather less severe than at the deeper CDP sites. Consequently, carbonate content of the sediment at this site is generally higher and less variable than at Sites 708 and 711; thus, modal WCMS values are proportionately lower and less variable, and the relationship between WCMS and carbonate content is correspondingly weaker ( $r=0.674$; see Table 1$)$. Despite the generally more subdued response of carbonate accumulation to regional CCD fluctuations at Site 710, relative to Sites 708 and 711, the main variable controlling WCMS fluctuations in Hole 710A still appears to be carbonate content of the sediment (Fig. 4), except within the interval between 48 and 70 mbsf (lithologic Subunit IB).

The WCMS profile for Hole 710A (Fig. 4) reveals, with comparable sensitivity, all of the lithostratigraphic information supplied by the $\%$-carbonate profile of this hole. The main difference between these two sets of data is the greater sensitivity with which WCMS differentiates between lithologic Subunits IA and IB. This is because lithologic Unit I at this site is subdivided according to differences in the oxidation state of the sediment (indicated by changes in color), which has affected the iron oxide and/or oxyhydroxide minerals it contains, thus altering its MS values. Hence, the oxic sediment of Subunit IA exhibits generally higher WCMS values than the suboxic/anoxic sediment of Subunit IB, because of reduction of magnetic iron oxides in the latter (see "Identification of Early Diagenesis" section, this chapter).
A second source of disparity between the responses of WCMS and carbonate content to downhole fluctuations in lithology at Site 710 is the inordinate sensitivity of WCMS to volcanic-ash horizons. The volcanic ash in tephra-rich horizons of deep-sea sediments may contain as much as $10 \%$ primary titanomagnetite (e.g., Kennett, 1981). Consequently, such horizons usually exhibit MS values that are orders-of-magnitude greater than pelagic lithologies. A clear example of the way in which volcanicash horizons totally dominate variations in WCMS of deep-sea sediments is provided by Site 706 (see Fig. 13 and accompanying text, below).

As noted above, the early and middle Miocene sequence of tropical Indian Ocean sediments is often condensed as a result of intensified dissolution of biogenic carbonate constituents, which occurred because of a pronounced shoaling of the regional CCD during this interval (van Andel, 1975). In Hole $710 \mathrm{~A}$, this interval is clearly associated both with much lower average carbonate percentages and with proportionately higher WCMS values (Fig. 4). A similar pattern of variation was observed in the records of both these parameters in the early and middle Miocene interval of all CDP holes (except at Site 707; see "Contamination by Drilling Artifacts" section, this chapter). The strength of correlation between these two parameters in CDP holes, however, appears to vary according to the water depth of the drilling site, with the degree of covariance being greater at the deeper sites.

The relationships between carbonate content and MS for CDP sites (Sites 708, 709, 710, and 711) are expressed quantitatively in Table 1 and graphically in Figure 5, based on statistical correlations between shipboard WCMS and carbonate content data taken from the "Physical Properties" (Table 1, upper, and 


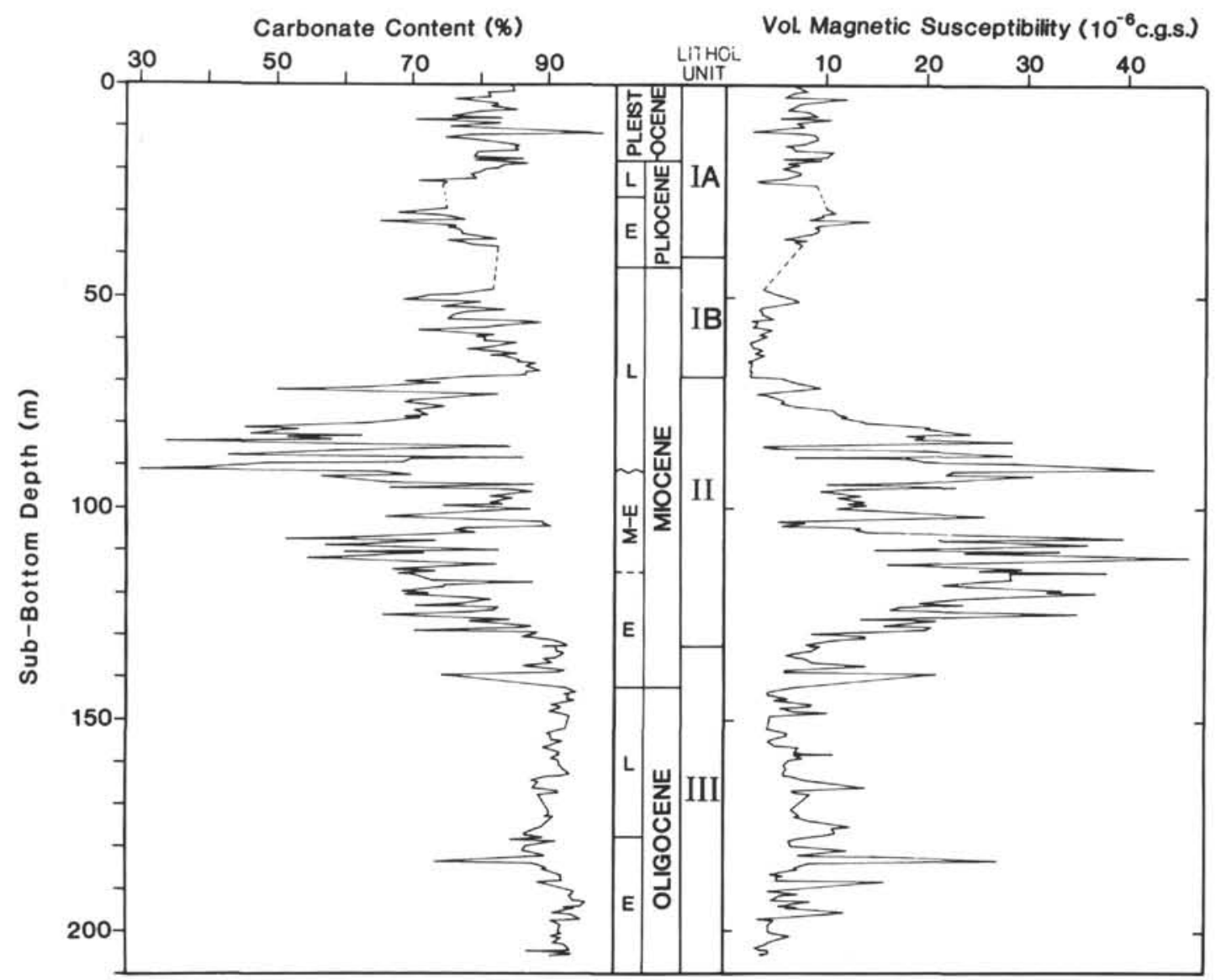

Figure 4. WCMS profile and \%-carbonate record of Hole 710A, showing the relationship between these parameters and lithologic units at this site. The \%-carbonate profile is based on shipboard ("Geochemistry") data.

Table 1. Coefficients of correlation (Pearson's $r$ ) expressing the relationship between magnetic susceptibility $(y)$ and carbonate content $(x)$ for Leg 115 "carbonate dissolution profile" holes, as illustrated in Figure 5.

\begin{tabular}{|c|c|c|c|}
\hline Hole & $\begin{array}{l}\text { Coefficient of } \\
\text { correlation }(r)\end{array}$ & $\begin{array}{l}\text { Number of } \\
\text { observations }\end{array}$ & $\begin{array}{l}\text { Source of } \\
\mathrm{CaCO}_{3} \text { data }\end{array}$ \\
\hline $708 \mathrm{~A}$ & -0.679 & 55 & \\
\hline 709A,B,C & -0.678 & 51 & Shipboard \\
\hline $710 A, B$ & -0.578 & 57 & "Physical \\
\hline $711 \mathrm{~A}, \mathrm{~B}$ & -0.739 & 46 & $\begin{array}{l}\text { Properties" } \\
\text { measurements }\end{array}$ \\
\hline $\begin{array}{l}\text { All above } \\
\text { holes' data } \\
\text { combined }\end{array}$ & -0.812 & 209 & \\
\hline $708 \mathrm{~A}$ & -0.507 & 175 & \\
\hline 709A,B & -0.222 & 174 & Shipboard \\
\hline $710 \mathrm{~A}$ & -0.674 & 295 & $\begin{array}{l}\text { "Geochemistry" } \\
\text { measurements }\end{array}$ \\
\hline $\begin{array}{l}\text { All above } \\
\text { holes' data } \\
\text { combined }\end{array}$ & -0.557 & 644 & \\
\hline $\begin{array}{l}709 \mathrm{C} \\
711 \mathrm{~A}\end{array}$ & $\begin{array}{l}-0.337 \\
-0.971\end{array}$ & $\begin{array}{l}196 \\
159\end{array}$ & $\begin{array}{l}\text { Present study } \\
\text { (post-cruise } \\
\text { measurements) }\end{array}$ \\
\hline $\begin{array}{l}\text { Above holes' } \\
\text { data combined }\end{array}$ & -0.990 & 355 & \\
\hline
\end{tabular}

Note: All correlation coefficients are statistically significant at the $99.9 \%$ probability level (Student's t-test).
Fig. 5A) and "Geochemistry" (Table 1, middle, and Fig. 5B) measurements as well as post-cruise measurements of carbonate content and MS of discrete samples (Table 1, lower, and Fig. 5C). Data shown in Figure 5C most faithfully reproduce the true nature of the relationship between MS and carbonate content at the scale of individual cores, since these data were obtained from samples taken at $5-\mathrm{cm}$ (Hole 711A) or 10-cm (Hole 709C) intervals, which is a rate of measurement narrower than the frequency of carbonate oscillations in these sediments (e.g., Fig. 2 ). In contrast, calcimetric data from shipboard "Geochemistry" measurements may be subject to aliasing, as a result of systematic sampling at intervals that are much wider than the frequency of carbonate cycles in the CDP sequences recovered. Also, only a small proportion of the carbonate data from shipboard "Physical Properties" measurements actually coordinate with the depths at which WCMS was measured. Thus, the carbonate-MS relationship shown in Figure 5A is based on a subsample that is not statistically representative of the background population of $\% \mathrm{CaCO}_{3} /$ WCMS values from Sites 708 through 711. Similarly, the sample upon which the relationship shown in Figure $5 \mathrm{~B}$ is based, though much larger, is heavily biased toward Hole 710A and contains no data at all from Site 711. Consequently, the correlation coefficient for the relationship between carbonate content and WCMS for CDP sites is lower in Figure $5 \mathrm{~B}$, which is based on shipboard "Geochemistry" data (biased toward the shallower sites, particularly Site 710), than it is in Figure 5A, which is based on shipboard "Physical Properties" data (more evenly distributed among all CDP sites, except Site 707). 


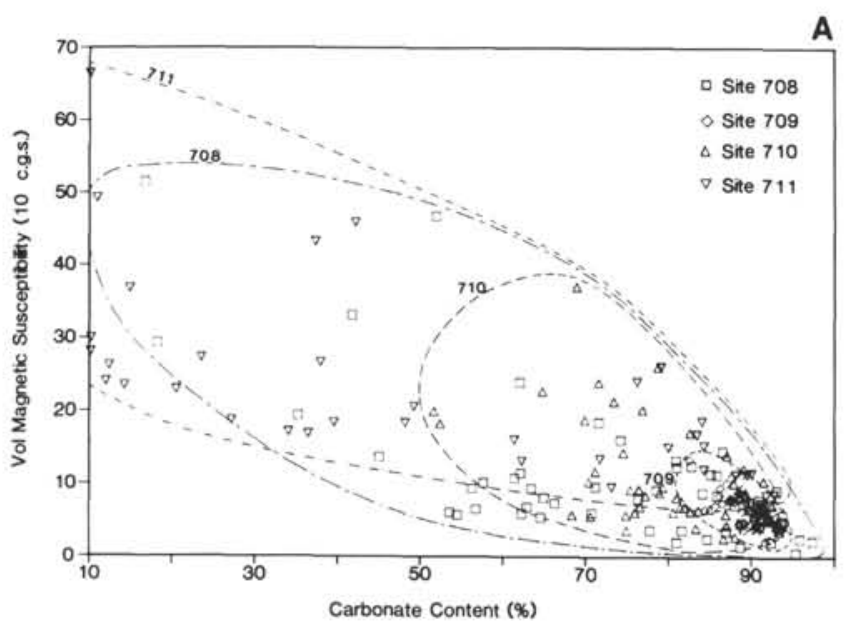

B
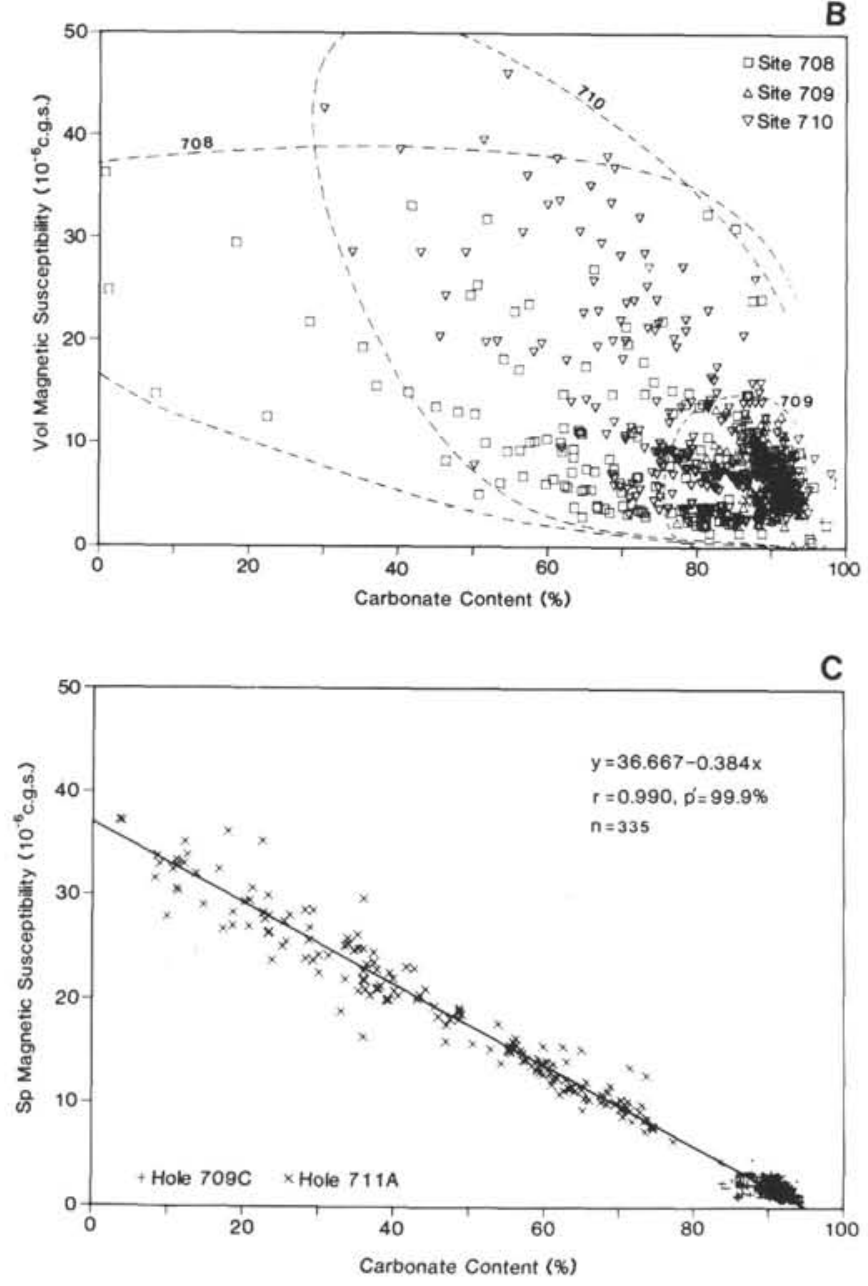

Figure 5. Relationships between magnetic susceptibility and carbonate content for several Leg 115 "Carbonate Dissolution Profile" sites. A. WCMS vs. \%0-carbonate (shipboard "Physical Properties'" data) for Sites $708,709,710$, and 711 . B. WCMS v. \%-carbonate (shipboard "Geochemistry" data) for Sites 708, 709, and 710. C. Discrete sample, mass-specific MS vs. \%-carbonate (this study) for Holes 709C (0-23 $\mathrm{mbsf})$ and $711 \mathrm{~A}(0-9 \mathrm{mbsf})$. Correlation coefficients for these relationships are listed in Table 1.
The data shown in Figure 5C, of course, would also be highly biased, were they used to represent the overall carbonateMS relationship for Sites 709 and 711, as they are derived solely from the (atypical) Quaternary intervals of Holes 709C and 711A. It is notable, however, that the form of the relationship between calcimetric and MS data from both sites is apparently the same. This is demonstrated by the fact that the coefficient of correlation between these two parameters is highest $(0.990)$ when data from both sites are combined, even though the correlation coefficient for their relationship at Site $709(0.337)$ is much lower than at Site 711 (0.971). This suggests that changes in biogenic silica content of the sediment at the shallower site (Hole 709C) have not significantly influenced MS variations, which therefore appear to be controlled mainly by carbonate dissolution effects, at least for the Quaternary interval of this site.

The relationships shown in Figure 5 confirm that, on average, as the water depth of the drilling site increases, (1) the carbonate content of the sediment falls, and MS values proportionately rise; (2) variability in MS and carbonate content increases; and (3) the dependence of MS on carbonate content of the sediment is greater. The lower strength of correlation between MS and carbonate content of the sediment at the shallower CDP sites reflects the lower intensity of carbonate dissolution at these sites, and thus the greater relative importance of secondary influences on MS variations, such as changes in biogenic silica content of the sediment or detrital mineral composition.

The last example in the present section (Fig. 6) shows the relationship between variations in WCMS and core lithology of eight gravity cores from the North Atlantic, taken in a region known as "King's Trough Flank" (KTF), approximately $360 \mathrm{~km}$ northeast of the Azores. The KTF cores consist of fairly pure, foraminifer-bearing nannofossil ooze, with interbedded horizons of detrital rich ooze (foraminifer-bearing, clayey nannofossil ooze to foraminfer-bearing nannofossil clay), corresponding to glacial intervals of the cores (Weaver, 1983; Kidd et al., 1983). In contrast to the sediments recovered during Leg 115, variations in the carbonate content of the KTF cores are unrelated to dissolution, but mainly result from dilution of the pelagic carbonate flux in this area during glacial periods, by ice-rafted terrigenous detritus (Robinson, 1986a, 1986b). Accordingly, carbonate-rich (interglacial) horizons of the KTF cores are characterized by low WCMS values (i.e., between 0 and $5 \times 10^{-6} \mathrm{cgs}$ ), whereas clay-rich (glacial) horizons exhibit higher average-though more variable-WCMS values (i.e., between 5 and $20 \times 10^{-6}$ cgs). Discrete peaks in WCMS within clay-rich glacial horizons, correspond to individual ice-rafting episodes that may be correlated directly with those identified by Heinrich (1988) in cores taken to the north of the KTF area, where they recur each half cycle of the 23-k.y. precessional period in the Earth's orbit.

The WCMS profiles of the KTF cores (Fig. 6) provide a good example of the strong lithologic control of MS variations for mid- (and high-) latitude deep-sea sediments recovered from sites lying well above the CCD and sedimentary lysocline, that is, sites that are free from the influence of carbonate dissolution. This contrasts with Leg 115 sites, where the strength of the relationship between WCMS and core lithology depends, to a large extent, on the water depth of the drilling site, and its subsequent effect on the accumulation rate of carbonate vis-a-vis lithogenic constituents of the sediment.

\section{Core Correlation and Tephrostratigraphy}

The main objective in logging MS variations of whole-core sections as they arrive on deck is to provide a means of high-resolution correlation between adjacent holes drilled at a given ODP site. An example of this application at its simplest is provided by Figure 7 , which shows the correlation between the 


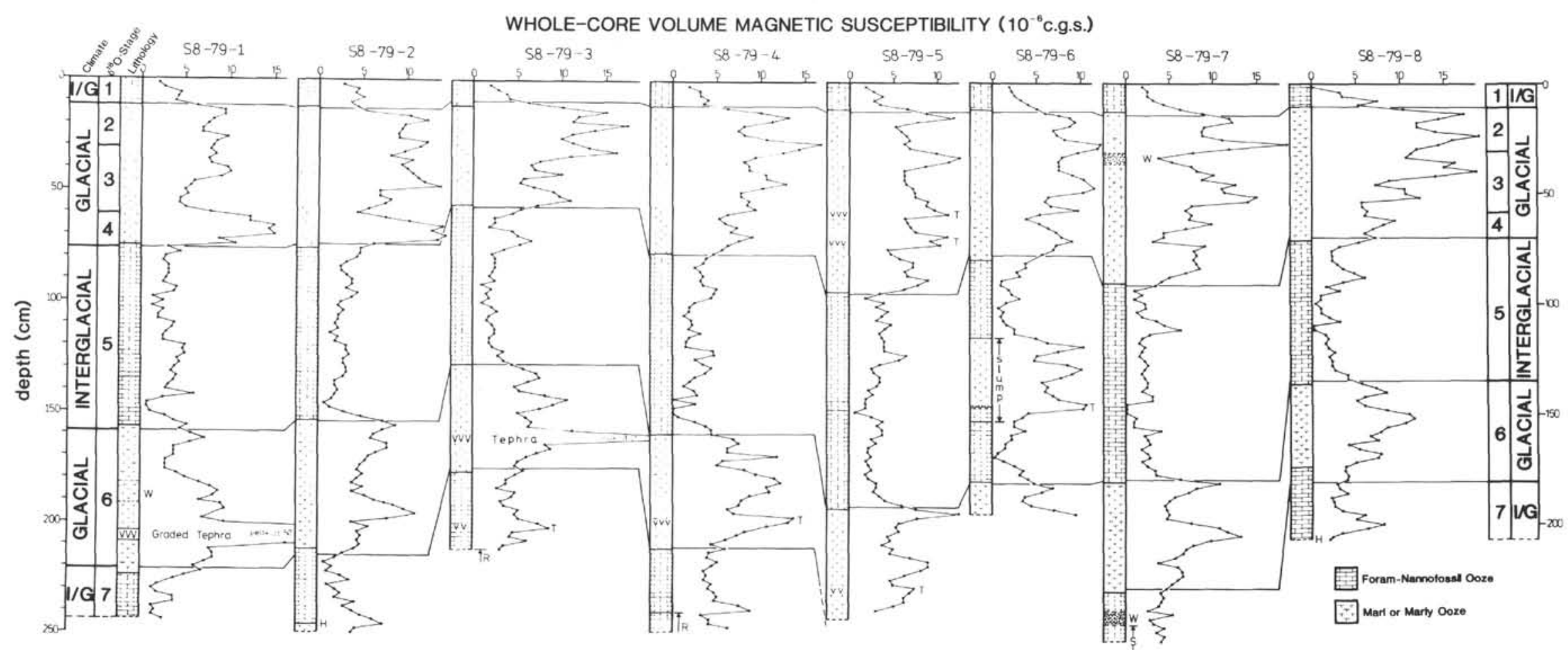

Figure 6. WCMS profiles, lithologic logs, and paleoclimatic records of eight deep-sea sediment cores from the King's Trough Flank region of the North Atlantic (cf. DSDP Site 608). T = tephrarich interval, $\mathrm{W}=$ winnowed horizon, $\mathrm{H}=$ hiatus, $\mathrm{R}=$ repeated sequence (caused by repenetration of the corer), and $\mathrm{S}=$ slumped horizon. 
Volume Magnetic Susceptibility $\left(10^{-6}\right.$ c.g.s. units $)$

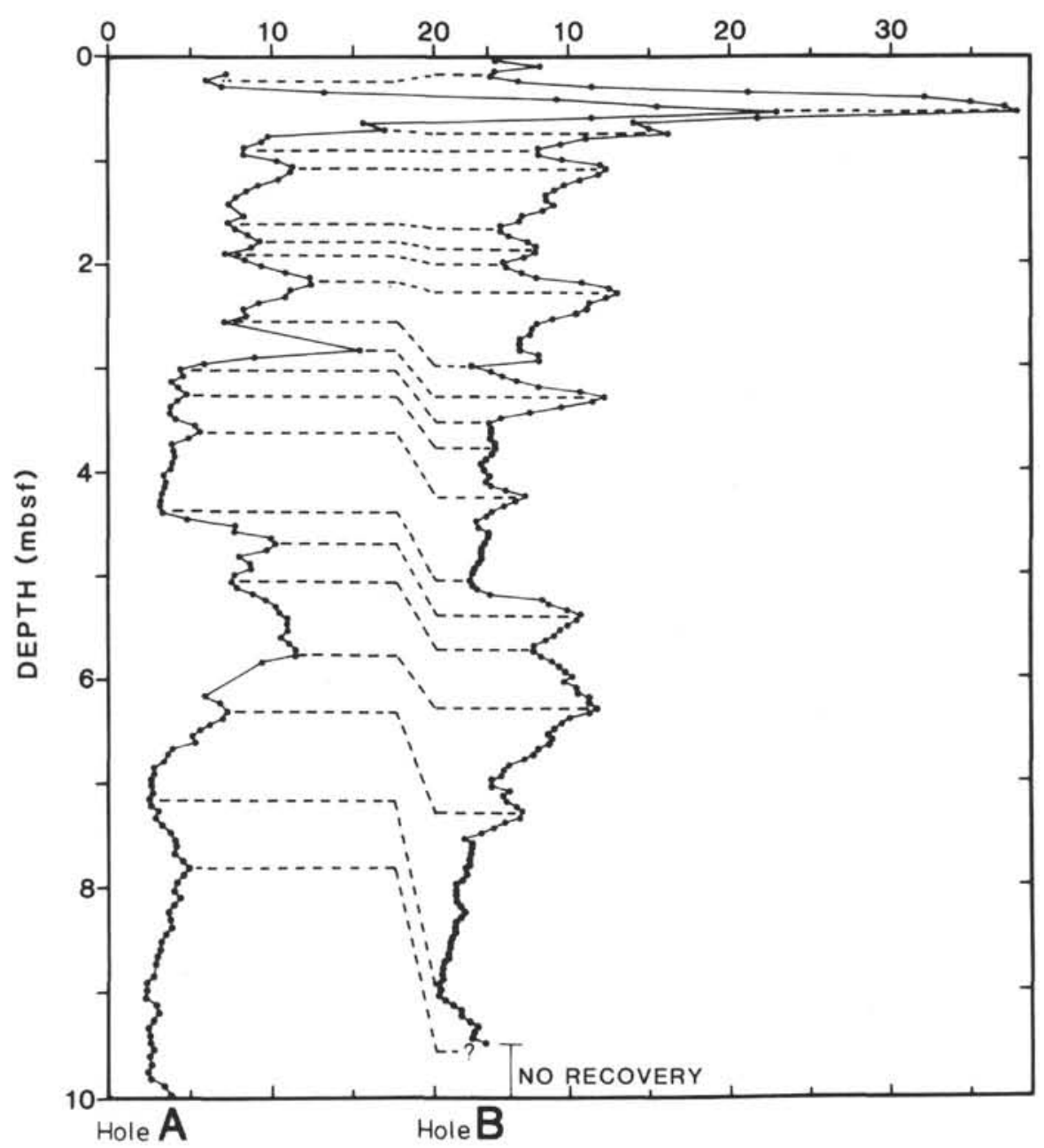

Figure 7. Lithostratigraphic correlation between the late Quaternary horizons of Holes 714A and 714B, based on WCMS profiles of each hole.

Pleistocene intervals of subsidiary holes drilled at Site 714, based on their WCMS profiles.

More than one hole is drilled at each ODP site because gaps in the stratigraphic record of HPC/APC-cored holes often correspond to the boundaries between cores. Accordingly, the run length of individual cored intervals in each hole, at any one site, is arranged such that the top and bottom of each core occurs at a sub-bottom depth that corresponds, more or less, to the middle of a coring run in the adjacent hole. In this way, it is theoretically possible to recover a complete record of the stratigraphic sequence of each site drilled, by "dovetailing" uninterrupted subsections of the sequence obtained by offset coring in subsidiary holes. To accomplish the task of reconstructing a stratigraphically uninterrupted, composite sequence from any one ODP site, therefore, a method for ultra-high-resolution, between-hole correlation is required. The aim of the following examples is to demonstrate that WCMS logging provides an ideal tool for this kind of operation.

As noted above, Figure 6 illustrates the strong lithologic control of MS variations for deep-sea sediments of the mid-latitude North Atlantic. This provides the basis for high-resolution intercorrelation of the KTF cores based on their WCMS profiles. The lines of correlation shown in Figure 6, however, connect the positions of glacial-interglacial stage boundaries in the cores, identified by analyses of oxygen isotope ratios and planktonic forminifer assemblages (Weaver, 1983). Clearly, many more lines of lithostratigraphic correlation could be drawn between obviously equivalent features in the WCMS profiles of these cores. Equally clear in Figure 6 is the strong palaeoclimatic influence on variations in lithology (i.e., carbonate content), and thus WCMS, in the KTF area (Robinson, 1986a). Therefore, the regional scale, WCMS-based intercorrelation of cores illustrated in Figure 6, may be of much wider significance (see "Paleoclimatic Investigations" section, this chapter) Moving down from the scale of regional, intersite correlation (Fig. 6), Figures 8 through 12 provide typical examples of the application for WCMS logging at individual ODP sites, outlined above.

Figure 8 shows a correlation between the uppermost $24 \mathrm{~m}$ of Holes 709A and 709C, based on their WCMS profiles. As Site 709 lies towards the shallower end of the CDP (Fig. 1), the sediments deposited here during the interval encompassed by the profiles shown in Figure 8 (late Pliocene through Pleistocene), consist of fairly pure calcareous oozes (generally between $80 \%$ and $95 \% \mathrm{CaCO}_{3}$ content), with only minor amounts of lithogenic clay (Backman, Duncan, et al., 1988, p. 465). Accordingly, the relationship between MS and carbonate content of the 


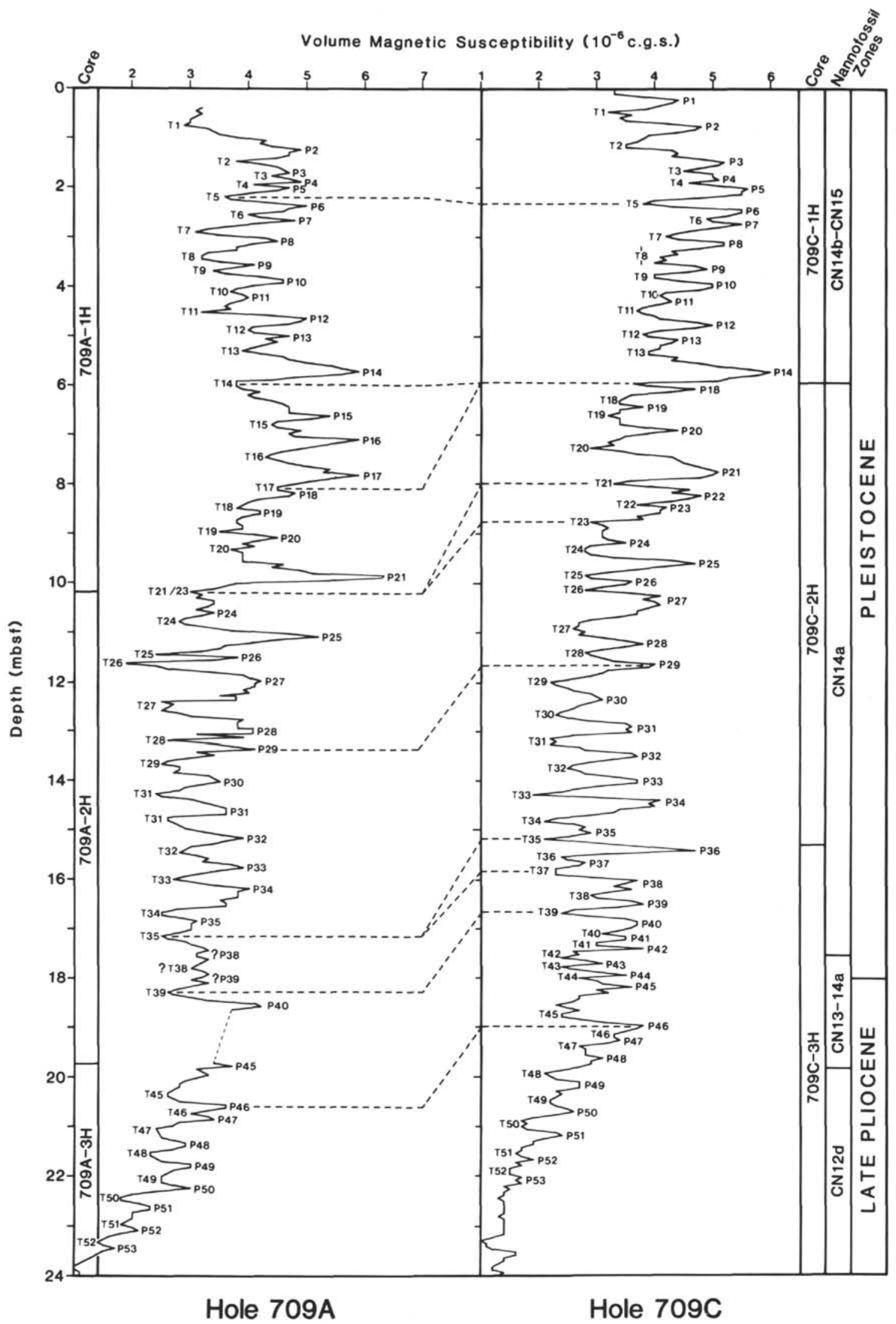

Figure 8. Lithostratigraphic correlation between the late Pliocene and Pleistocene horizons of Holes 709A and 709C, based on their WCMS profiles. The depths in each hole at which the correlation points ( $\mathrm{P} 1, \mathrm{~T} 1, \mathrm{P} 2, \mathrm{~T} 2$, etc.) indicated in this figure were identified are listed in Table 2. Note the degradation of the WCMS signal in each hole below P50 caused by the effects of early diagenesis. 
sediment, for the interval of Hole 709C shown in Figure 8, for example, is relatively weak $(r=0.337)$ when compared with that of the deeper CDP sites (Table 1). Nevertheless, the WCMS profiles of the carbonate-rich, Pliocene-Pleistocene sediments recovered from Holes 709A and 709C are sufficiently detailed to provide over 100 points of lithostratigraphic correlation between these holes. For reference purposes, these correlation points have been labeled in Figure 8 as follows: P1, P2, P3, .., and so on, for peaks in the WCMS profiles of these holes, and T1, T2, $\mathrm{T} 3, \ldots$, and so on, for the intervening troughs in WCMS values. Table 2 lists the depths in each hole at which the points of correlation identified in Figure 8 were recognized. (Note that there is no implied correlation between points labeled P1, T1, P2, T2, and so on, in Figure 8 and correlation points assigned the same labels in subsequent figures.) Correlation points were identified by cross-matching the stratigraphic position, relative amplitude, and overall configuration both of peaks and troughs in the WCMS profile of each hole.

Table 2. Depths in Holes 709A and 709C at which points of lithostratigraphic correlation between these holes were identified in Figure 8, based on cross-matching peaks (P1, P2, P3, etc.) and troughs (T1, T2, T3, etc.) in their WCMS profiles.

\begin{tabular}{|c|c|c|c|c|c|}
\hline $\begin{array}{c}\text { Correlation } \\
\text { point }\end{array}$ & $\begin{array}{l}\text { Depth in } \\
\text { Hole 709A } \\
\text { (mbsf) }\end{array}$ & $\begin{array}{l}\text { Depth in } \\
\text { Hole 709C } \\
\text { (mbsf) }\end{array}$ & $\begin{array}{c}\text { Correlation } \\
\text { point }\end{array}$ & $\begin{array}{l}\text { Depth in } \\
\text { Hole 709A } \\
\text { (mbsf) }\end{array}$ & $\begin{array}{c}\text { Depth in } \\
\text { Hole 709C } \\
\text { (mbsf) }\end{array}$ \\
\hline $\mathrm{T} 1$ & 0.71 & 0.50 & $\mathrm{~T} 27$ & 12.59 & 10.94 \\
\hline P2 & 1.28 & 0.79 & P28 & 12.96 & 11.25 \\
\hline $\mathrm{T} 2$ & 1.49 & 1.09 & T28 & 13.20 & 11.45 \\
\hline P3 & 1.70 & 1.47 & P29 & 13.36 & 11.70 \\
\hline T3 & 1.78 & 1.64 & T29 & 13.66 & 12.09 \\
\hline P4 & 1.89 & 1.79 & P30 & 14.00 & 12.38 \\
\hline $\mathrm{T} 4$ & 1.96 & 1.89 & T30 & 14.30 & 12.69 \\
\hline P5 & 2.06 & 2.07 & P31 & 14.61 & 12.99 \\
\hline T5 & 2.21 & 2.30 & $\mathrm{~T} 31$ & 14.81 & 13.21 \\
\hline P6 & 2.42 & 2.50 & P32 & 15.18 & 13.49 \\
\hline T6 & 2.59 & 2.65 & T32 & 15.48 & 13.73 \\
\hline P7 & 2.69 & 2.72 & P33 & 15.80 & 14.00 \\
\hline $\mathrm{T} 7$ & 2.91 & 2.98 & $\mathrm{~T} 33$ & 16.01 & 14.29 \\
\hline P8 & 3.10 & 3.10 & P34 & 16.27 & 14.49 \\
\hline T8 & 3.41 & 3.43 & T34 & 16.71 & 14.81 \\
\hline P9 & 3.59 & 3.62 & P35 & 16.96 & 15.01 \\
\hline $\mathrm{T} 9$ & 3.70 & 3.78 & T35 & 17.17 & 15.21 \\
\hline P10 & 3.90 & 3.96 & P36-P37 & \multicolumn{2}{|c|}{ Missing from Hole } \\
\hline $\mathrm{T} 10$ & 4.09 & 4.15 & & \multicolumn{2}{|c|}{$709 \mathrm{~A}$} \\
\hline P11 & 4.15 & 4.29 & T37 & 17.17 & 15.76 \\
\hline $\mathrm{T} 11$ & 4.53 & 4.48 & P38 & $17.58(?)$ & 16.15 \\
\hline P12 & 4.70 & 4.75 & T38 & $17.81(?)$ & 16.34 \\
\hline $\mathrm{T} 12$ & 4.91 & 4.93 & P39 & $17.98(?)$ & 16.50 \\
\hline P13 & 5.09 & 5.14 & T39 & 18.29 & 16.70 \\
\hline T13 & 5.33 & 5.32 & P40 & 18.59 & 16.90 \\
\hline P14 & 5.71 & 5.72 & $\mathrm{~T} 40-\mathrm{T} 44$ & \multicolumn{2}{|c|}{ No recovery from Hole } \\
\hline T14 & 5.92 & 5.91 & \multicolumn{3}{|c|}{$709 \mathrm{~A}$} \\
\hline P15-P17 & \multicolumn{2}{|c|}{$\begin{array}{l}5.92 \\
\text { Missing from Hole }\end{array}$} & P45 & 19.78 & 18.16 \\
\hline & \multicolumn{2}{|c|}{$709 \mathrm{C}$} & T45 & 20.47 & 18.67 \\
\hline $\mathrm{T} 17$ & 8.09 & 5.91 & P46 & 20.59 & 18.98 \\
\hline P18 & 8.20 & 6.07 & $\mathrm{~T} 46$ & 20.75 & 19.19 \\
\hline $\mathrm{T} 18$ & 8.50 & 6.30 & P47 & 20.85 & 19.29 \\
\hline P19 & 8.58 & 6.41 & T47 & 21.12 & 19.48 \\
\hline T19 & 8.90 & 6.61 & P48 & 21.38 & 19.68 \\
\hline P20 & 9.10 & 6.90 & $\mathrm{~T} 48$ & 21.59 & 19.91 \\
\hline $\mathrm{T} 20$ & 9.39 & 7.19 & P49 & 21.81 & 20.13 \\
\hline P21 & 9.88 & 7.75 & T49 & 22.07 & 20.48 \\
\hline $\mathrm{T} 21$ & 10.20 & 7.99 & P50 & 22.25 & 20.70 \\
\hline $\mathrm{P} 22-\mathrm{P} 23$ & \multicolumn{2}{|c|}{ Missing from Hole } & T50 & 22.49 & 20.93 \\
\hline & \multicolumn{2}{|c|}{$709 \mathrm{~A}$} & P51 & 22.64 & 21.15 \\
\hline $\mathrm{T} 23$ & 10.20 & 8.80 & TS1 & 22.96 & 21.53 \\
\hline P24 & 10.68 & 9.19 & P52 & 23.10 & 21.61 \\
\hline $\mathrm{T} 24$ & 10.81 & 9.35 & T52 & 23.32 & 21.89 \\
\hline P25 & 11.10 & 9.61 & P53 & 23.48 & 22.05 \\
\hline T25 & 11.48 & 9.85 & & & \\
\hline P26 & 11.56 & 9.99 & \multirow{3}{*}{$\begin{array}{c}\text { Note: } P= \\
\text { trough. }\end{array}$} & \multirow{3}{*}{\multicolumn{2}{|c|}{ WCMS peak and $T=$}} \\
\hline $\mathrm{T} 26$ & 11.65 & 10.16 & & & \\
\hline P27 & 12.10 & 10.43 & & & \\
\hline
\end{tabular}

As indicated by the dashed lines of correlation in Figure 8, the section in Hole 709A between T14 and T17 is absent from the WCMS profile of Hole 709C. Similarly, the section in Hole $709 \mathrm{C}$ between T21 and T23 is absent from the WCMS profile of Hole 709A. In both instances, these stratigraphic discontinuities are the result of sediment lost, or simply not sampled, between coring runs, and subsequently not recorded because of inaccuracies in calculating the sub-bottom depth assignments for these holes. Coring irregularities of this kind are considered in more detail below (see "Unidentified Gaps at Core Boundaries" section, this chapter).

Figure 9 shows the WCMS-based correlation between Holes 709A and 709C, plotted in the form of a Shaw Diagram (Shaw, 1964), that was constructed from the data listed in Table 2 . This plot clearly demonstrates the high degree of lithostratigraphic resolution with which WCMS is able to correlate between these holes. In this form of correlation diagram, gaps in the stratigraphic record of each hole, resulting from loss of material between cores, are clearly revealed as segments of the correlation curve that lie parallel to one or other of the graph's axes. Gaps caused by coring irregularities of this kind may, in general, be differentiated from real stratigraphic discontinuities only by the coincidence of core boundaries at the positions in the sequence at which the gaps occur.

In contrast to Site 709 , Site 711 lies at the deep end of the CDP (Fig. 1). The sediments that accumulate at this site, therefore, generally contain less carbonate than those of Site 709 and thus exhibit higher WCMS values. WCMS values are also likely to be more strongly related to variations in lithology (i.e., carbonate content) at Site 711 than they are at Site 709 (see Fig. 5C). Therefore, the effectivenes of WCMS as a lithostratigraphic correlation tool is likely to be even better at Site 711 than it is at Site 709 (e.g., Figs. 8 and 9).

Figure 10 shows the correlation between the WCMS profiles of Holes 711A and 711B, to a sub-bottom depth of $12 \mathrm{~m}$. Note the generally higher WCMS values, and also the greater amplitude of oscillations in WCMS (mirroring carbonate content; e.g., Fig. 3), at this site relative to Site 709. The strong dependence of WCMS on carbonate content of the sediment at this site $(r=0.971)$, naturally provides a sound basis for lithostratigraphic correlation between Holes $711 \mathrm{~A}$ and $711 \mathrm{~B}$, based on their WCMS profiles. Correlation points identified in Figure 10 are again letter and number coded (i.e., P1, T1, P2, T2, etc.) for ease of reference and comparison. The depths at which these correlation points were identified in each hole at Site 711 are listed in Table 3. The WCMS-based correlation between Holes $711 \mathrm{~A}$ and $711 \mathrm{~B}$ shown in Figure 10 is plotted in the form of a Shaw Diagram in Figure 11. Figures 10 and 11 both clearly reveal that gaps occur in the stratigraphic record of each hole at Site 711, between individual cored intervals of the sequences recovered. In Hole $711 \mathrm{~A}$, an interval is missing between Cores $115-711 \mathrm{~A}-1 \mathrm{H}$ and $-2 \mathrm{H}$, equivalent to the sequence in Hole $711 \mathrm{~B}$ between P14 and P23 (= $2.4 \mathrm{~m})$. In Hole 711B, an interval of the sequence is missing between Cores $115-711 \mathrm{~B}-1 \mathrm{H}$ and $-2 \mathrm{H}$, equivalent to the sequence in Hole $711 \mathrm{~A}$ between T5 and T9 $(=$ $2.4 \mathrm{~m}$ ). It is significant that the equivalent length of core missing from each hole at this site, between the first two cores in each sequence recovered, is exactly $2.4 \mathrm{~m}$, further supporting the inference that these missing intervals are the result of coring irregularities. In Figure 11, gaps in the sequences of Holes 711A and $711 \mathrm{~B}$, presumably caused by coring irregularities, are clearly identified as major "steps" in the correlation curve for these holes.

The main purposes for which the type of data listed in Table 3 , and plotted in Figure 11, are gathered are to (1) enable bioand magnetostratigraphic datums recognized in one hole to be extrapolated to the other, and (2) to assist the process of recon- 


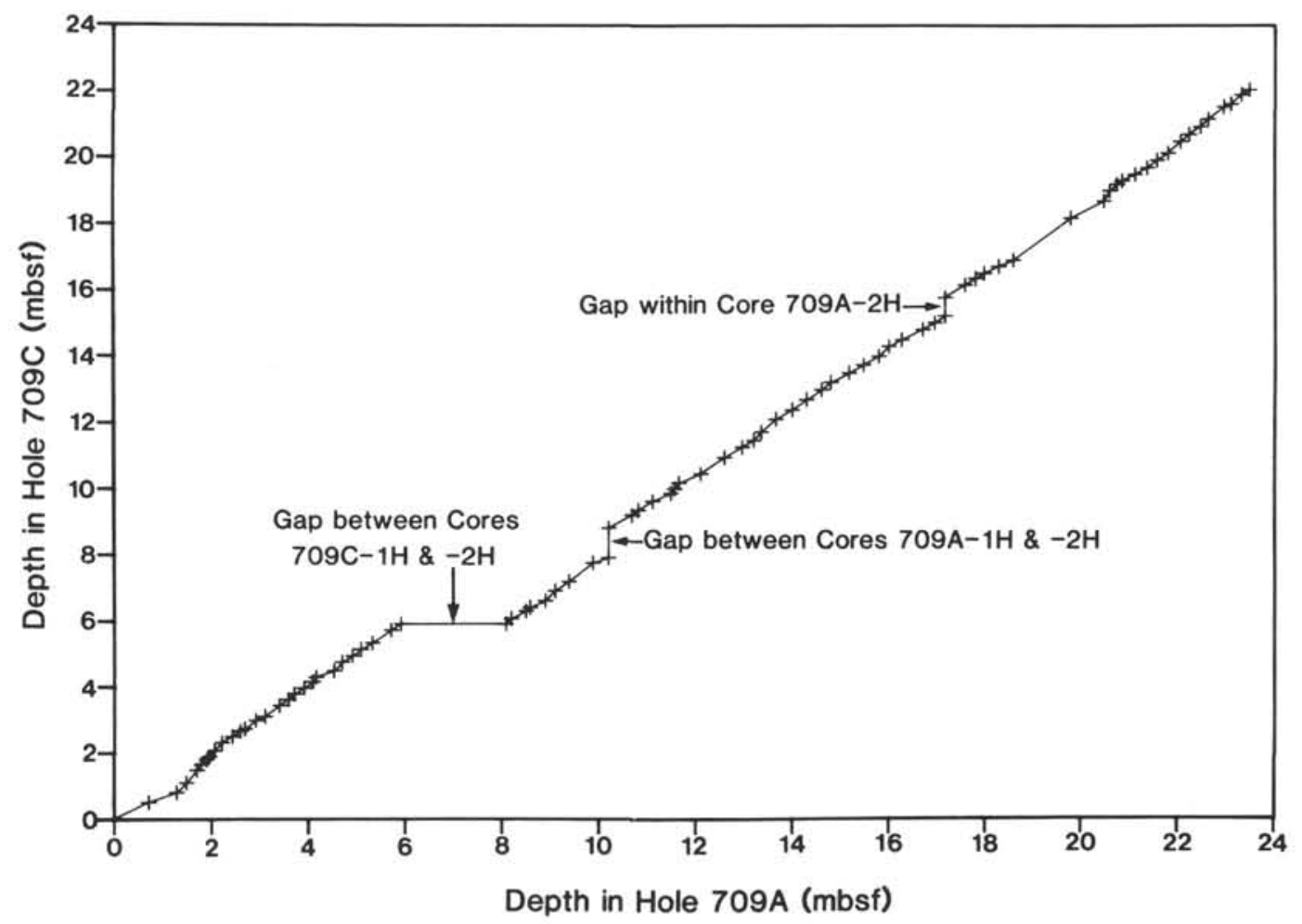

Figure 9. Shaw Diagram correlating depth in Hole 709A with depth in Hole 709C, based on cross-matching the WCMS profiles of each hole (Fig. 8). The data used to construct this plot are listed in Table 2.

structing a stratigraphically uninterrupted, composite sub-bottom depth model for a given site. Figure 12 shows a composite WCMS profile for Site 711, to an adjusted sub-bottom depth of $15 \mathrm{~m}$, obtained by splicing the WCMS profiles of uninterrupted subsections of Holes 711A and 711B, as shown in Figure 10. Table 4 lists the depths at which the composite, WCMS-based, sub-bottom depth model for the Site 711 (to an adjusted depth of $40 \mathrm{mbsf}$ ) switches between Holes 711A and 711B, to avoid gaps in the recovered sequences caused by coring irregularities (major turbidite horizons have also been eliminated).

A clear demonstration of the usefulness of WCMS logging in studies of marine tephrostratigraphy ("tephrochronology") is provided by Figure 13. This figure shows the WCMS profiles of Holes 706A and 706B to a sub-bottom depth of $20 \mathrm{~m}$, plotted alongside lithologic logs of these holes taken from shipboard core description data. Correlatable features in the WCMS profiles shown in Figure 13 are again labeled from the top of each hole downwards: P1, T1, P2, T2, and so on, according to whether the correlation point corresponds either to a peak $(\mathrm{P})$ or trough (T) in the WCMS profile of each hole. The depths in each hole at Site 706 at which these correlation points were identified are listed in Table 5.

As indicated by reference to the lithologic logs shown in Figure 13, WCMS variations at Site 706 are almost entirely controlled by the character and distribution of volcanic-ash horizons in the sequence. The response of WCMS to variations in pelagic lithology between volcanic-ash horizons at this site is totally masked by the generally high "background" levels in WCMS, which are higher even than the maximum WCMS values attained at Sites 709 and 710 . The high "background" values of WCMS at Site 706 are probably related to the presence of minor amounts of volcanic ash dispersed throughout the sequence by bioturbation. Above "background" levels, a series of prominent peaks in the WCMS profiles of Holes 706A and 706B appear in response to discrete volcanic-ash-rich horizons, and rise to values of between 1.0 and $1.5 \times 10^{-4} \mathrm{cgs}$ (often deflected off-scale in Fig. 13). The intensity of these WCMS peaks is probably related directly to the initial concentration, and extent of postdepositional alteration (reduction), of volcanic ash in the sediment.

In many of the greenish gray, degraded volcanic-ash horizons in Holes 706A and 706B, discrete crystals of pyrite were observed that exhibited framboidal morphology, indicative of an authigenic origin involving iron and sulfate-reducing bacteria (Curtis, 1983). The much lower WCMS values exhibited by degraded, as distinct from unaltered, volcanic-ash horizons are probably caused, therefore, by "dissolution" and pyritization of primary titanomagnetite grains that were originally present in the volcanic ash before these horizons were reduced (cf. Canfield and Berner, 1987). The change in the level of "background" WCMS values that occurs at around $7.5 \mathrm{mbsf}$ in both holes at Site 706 is also related to a change in the oxidation state (indicated by a change in color) of the sediment, and thus its magnetic iron oxide content, at this point in the sequence.

The lines of correlation drawn between the WCMS profiles in Figure 13 highlight the gaps that occur at different depths in the sequence of each hole at Site 706, resulting both from real stratigraphic discontinuities and from coring irregularities. Figure 14 plots the correlation between the WCMS profiles of Holes 706A and 706B in the form of a Shaw Diagram, based on the data listed in Table 5 .

A significant unconformity occurs in both holes at Site 706, separating the uppermost lithologic unit at this site, which consists of foraminifer ooze of Pleistocene age, from the remainder of the sequence, which consists of nannofossil oozes of early Oligocene age, containing numerous volcanic-ash horizons. How- 


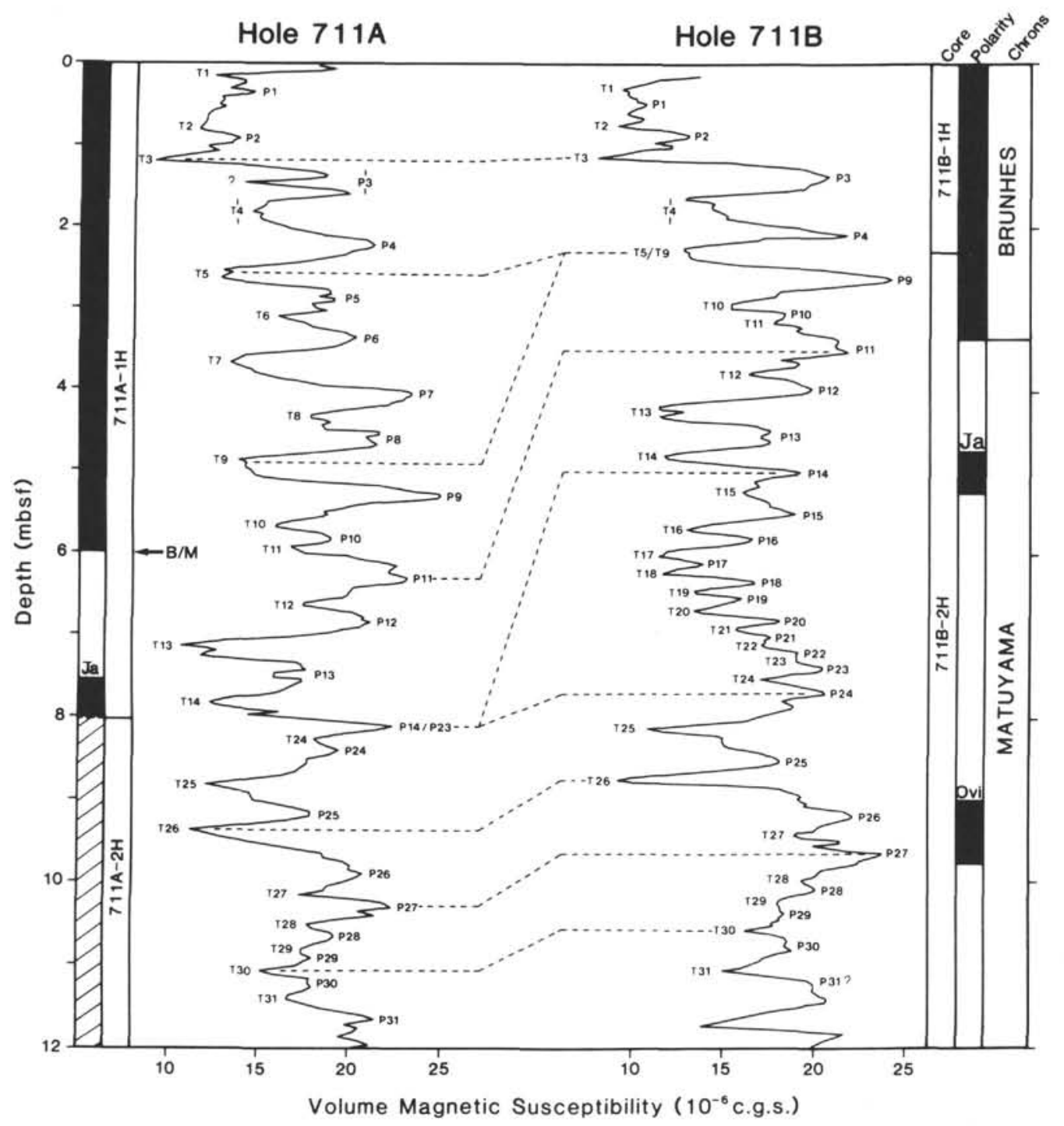

Figure 10. Lithostratigraphic correlation between the Quaternary horizons of Holes 711A and 711B, based on their WCMS profiles. The depths in each hole at which the correlation points indicated in this figure were identified are listed in Table 3. Note the major discontinuities in the sequence of each hole at core boundaries, corresponding to "unrecorded intervals of no recovery."

ever, an interval of at least $1 \mathrm{~m}$ in thickness, which corresponds to a sequence in Hole 706A somewhere between P3 and T3, is missing from Hole $706 \mathrm{~B}$ beneath the unconformity at $\sim 3.3$ mbsf. Further down-sequence, an interval that is at least equivalent to that which occurs in Hole 706B between P5 and T11 (approximately $4 \mathrm{~m}$ in thickness) is missing from the sequence of Hole 706A because of a second, this time angular (erosional), unconformity in this hole at $\sim 6.25$ mbsf.

The gaps that occur in the records of Holes 706A and 706B further down-sequence are clearly the result of coring irregularities. In Hole 706B, an interval is missing between Cores 115$706 \mathrm{~B}-2 \mathrm{H}$ and $-3 \mathrm{H}$ that is at least equal in thickness to the sequence in Hole 706A between T22 and P31 (approximately $2 \mathrm{~m}$, possibly as much as $4 \mathrm{~m}$ if the interval of zero recovery in Hole $706 \mathrm{~A}$ between $10.4 \mathrm{~m}$ and $12.1 \mathrm{mbsf}$ is included). In Hole 706A, a void occurs in Core $115-706 \mathrm{~A}-3 \mathrm{H}(-18.75 \mathrm{mbsf})$ that represents a gap in the recovered sequence equivalent to the interval in Hole 706B between T40 and T48 (approximately $2.75 \mathrm{~m}$ ). Loss of material from the middle of a core like this may have been caused by repenetration of the corer, with material lost or not sampled (i.e., washed) between successive penetrations of the corer, within a single coring run. An alternative explanation is that this gap represents a real stratigraphic discontinuity (i.e., a diastem) in this instance.

Figures 13 and 14 clearly demonstrate the complexities involved in reconstructing the lithostratigraphic record of Site 706 from the sequences recovered from Holes 706A and 706B, a task that would be extremely difficult without the assistance of a technique for high-resolution, between-hole correlation.

A final example in the present section involves a change of scale back up to that of regional, intersite correlation. This time, however, the correlation is between entire holes drilled at different sites along the Leg 115 CDP transect (Fig. 1), based on their WCMS profiles (Fig. 15). On a scale as large as this, it is impossible to illustrate clearly the high-resolution (3-6 cm spaced) WCMS variations of each hole that provided the basis for the interhole correlations described above. Hence, only a simplified (10-point moving average, turbidite-free) version of the WCMS 
Table 3. Depths in Holes 711A and $711 B$ at which points of lithostratigraphic correlation between these holes were identified in Figure 10, based on cross-matching the WCMS profiles of each hole.

\begin{tabular}{|c|c|c|}
\hline $\begin{array}{l}\text { Correlation } \\
\text { point }\end{array}$ & $\begin{array}{l}\text { Depth in } \\
\text { Hole } 711 \mathrm{~A} \\
\text { (mbsf) }\end{array}$ & $\begin{array}{l}\text { Depth in } \\
\text { Hole } 711 \mathrm{~B} \\
\text { (mbsf) }\end{array}$ \\
\hline T1 & 0.50 & 0.35 \\
\hline P1 & 0.66 & 0.49 \\
\hline $\mathrm{T} 2$ & 0.80 & 0.68 \\
\hline P2 & 0.95 & 0.88 \\
\hline T3 & 1.20 & 1.13 \\
\hline P3 & 1.50 & 1.39 \\
\hline T4 & 1.85 & 1.75 \\
\hline P4 & 2.23 & 2.09 \\
\hline T5 & 2.60 & 2.30 \\
\hline P5-P8 & \multicolumn{2}{|c|}{$\begin{array}{l}\text { Missing from Hole } \\
711 \mathrm{~B}\end{array}$} \\
\hline T9 & 5.00 & 2.30 \\
\hline P9 & 5.32 & 2.62 \\
\hline T10 & 5.69 & 2.95 \\
\hline P10 & 5.85 & 3.10 \\
\hline T11 & 5.98 & 3.18 \\
\hline P11 & 6.26 & 3.42 \\
\hline $\mathrm{T} 12$ & 6.64 & 3.80 \\
\hline P12 & 6.85 & 3.98 \\
\hline $\mathrm{T} 13$ & 7.18 & 4.26 \\
\hline P13 & 7.49 & 4.56 \\
\hline T14 & 7.82 & 4.80 \\
\hline P14 & 8.11 & 5.00 \\
\hline T15-T23 & \multicolumn{2}{|c|}{$\begin{array}{l}\text { Missing from Hole } \\
711 \mathrm{~A}\end{array}$} \\
\hline P23 & 8.11 & 7.40 \\
\hline $\mathrm{T} 24$ & 8.30 & 7.52 \\
\hline $\mathrm{P} 24$ & 8.40 & 7.70 \\
\hline $\mathrm{T} 25$ & 8.82 & 8.12 \\
\hline P25 & 9.20 & 8.51 \\
\hline T26 & 9.40 & 8.76 \\
\hline P26 & 9.91 & 9.20 \\
\hline T27 & 10.11 & 9.40 \\
\hline P27 & 10.33 & 9.71 \\
\hline T28 & 10.55 & 9.99 \\
\hline P28 & 10.66 & 10.09 \\
\hline T29 & 10.83 & 10.26 \\
\hline P29 & 10.92 & 10.39 \\
\hline T30 & 11.10 & 10.58 \\
\hline P30 & 11.21 & 10.77 \\
\hline T31 & 11.40 & 11.07 \\
\hline P31 & 11.68 & 11.24 \\
\hline
\end{tabular}

Note: $\mathrm{P}=$ WCMS peak and $\mathrm{T}=$ trough.

profiles obtained from Holes 708A, 709A/709B (composite), $710 \mathrm{~A}$, and $711 \mathrm{~A}$ are shown in Figure 15, to clarify (1) the macroscale relationship between lithologic units (effectively equivalent to lithostratigraphic formations) and their WCMS profiles, as well as (2) the correlation between equivalent lithologic units at different sites based on their WCMS profiles.

Probably the most reliable between-site correlations shown in Figure 15 are based on cross-matching the major deflections in the WCMS profiles of each hole within the early Oligocene interval, which correspond to regional volcanic-ash horizons. Most notable in this figure, however, is the way in which the early and middle Miocene interval in each hole is characterized by a significant increase in WCMS values, roughly in proportion to the water depth of the drilling site. The deeper the drilling site, the more pronounced is the increase in WCMS values within the early and middle Miocene interval of the hole, and the more condensed this interval becomes relative to the remainder of the recovered sequence. This is the condensed, early through middle Miocene sequence referred to above that corre- sponds to a period of intensified carbonate dissolution in the western Indian Ocean, caused by a major shoaling of the regional CCD during this interval (van Andel, 1975).

Also of regional (northwest Indian Ocean) significance in Figure 15 is the interval of reduced (greenish-gray-colored) sediment between the base of the late Miocene and uppermost Pliocene or early Pleistocene horizons of each hole. This interval is characterized by distinctly lower WCMS values (except for volcanic-ash horizons) than would otherwise have been the case had not early diagenesis, involving reduction of iron oxides in the sediment, affected this interval. This is suggested by the much weaker relationship between carbonate content and WCMS for this reduced interval, relative to the strong correlation between these two parameters above and below this interval of CDP holes (see "Core Logging" section, this chapter). The effects of early diagenesis on the WCMS characteristics of CDP sequences are most pronounced at the shallowest site shown in Figure 15 (Site 709), and become less obvious as the sites deepen. A more detailed account of this interval of reduced sediment in Leg 115 holes is given below (see "Identification of Early Diagenesis" section, this chapter).

\section{Identification of Coring and Drilling Disturbance}

This section considers the use of WCMS logs to detect three kinds of coring irregularity that commonly affect ODP sequences. These are (1) unidentified gaps in the sequence at core boundaries; (2) repetition of sequence because of repenetration of the corer; and (3) contamination of cores by drilling artifacts, or mechanically reworked material containing such artifacts. Each of these three kinds of disturbance has adverse effects on the stratigraphic continuity of the sequences recovered from ODP holes.

\section{Unidentified Gaps at Core Boundaries}

This type of coring irregularity is most readily identified by correlating between offset cores taken from adjacent holes at a given site, by means of high-resolution WCMS logging. Several examples of this form of disturbance, and its detection by WCMS profiling, have already been illustrated earlier in this paper (Figs. 8 through 11, 13, and 14). Further (incidental) examples are provided in Figures 16, 17, and 18. Gaps may be detected between successive cored intervals of a given hole, when a sequence of WCMS variations in the adjacent hole at that site appears to be absent from the first hole, and the lines of correlation between the two holes, for the horizons immediately above and below the missing sequence, converge at a core boundary. However, because of a miscalculation in the sub-bottom depth assignment for this point in the sequence, no record is made of an interval of "no recovery." Sub-bottom depth miscalculations are often the result of inadequate compensation for unwanted vertical displacements of the drill string, caused both directly by surface waves, and indirectly by the effects of subsurface currents (Ruddiman et al., 1987). Such uncompensated displacements may cause the drill bit to wash down further than intended (or recorded by drilling platform instruments) between successive coring runs. Accordingly, spurious stratigraphic discontinuities of this kind may, for convenience, be referred to as "unrecorded intervals of no recovery."

\section{Repetition of Sequence Caused by Repenetration of the Corer}

A thorough examination of the causes and effects of repenetration during hydraulic piston coring was conducted by Ruddiman et al. (1987), based on an analysis of DSDP Leg 94 cores. An earlier study of repenetration features in open-barrel, gravity cores was documented by Weaver and Schultheiss (1983). This kind of coring irregularity results in the repetition of a sequence previously cored, often at the expense of an interval un- 


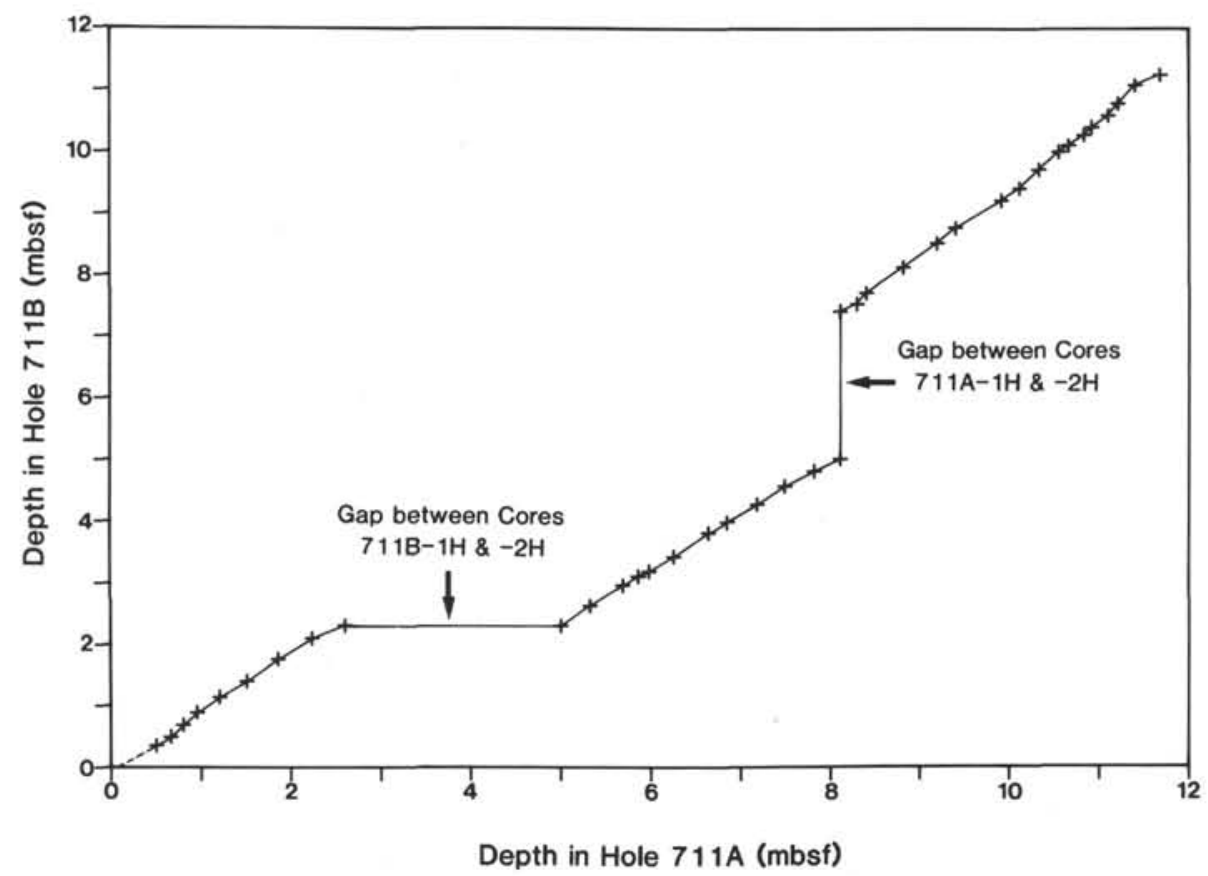

Figure 11. Shaw Diagram correlating depth in Hole 711A with depth in Hole 711B, based on crossmatching the WCMS profiles of each hole (Fig. 10). The data used to construct this plot are listed in Table 3.

derlying that which was captured during the initial penetration of the corer, and equal in thickness to that of the repeated sequence. This effect may imply that a real stratigraphic discontinuity or a "unrecorded interval of no recovery" occurs in the adjacent hole at that site, if the repeated sequence remains undiscovered. Unless biostratigraphic datums are repeated by the recoring of a sequence, it is extremely difficult to detect the presence of repenetration features within cores without the assistance of a quantitative technique for high-resolution, lithologically related core logging.

Figure 16 shows the WCMS profiles obtained from Holes 709A and 709B for the early Miocene interval between 153.5 and 178 mbsf. Detailed correlation between these high-resolution profiles (6- $\mathrm{cm}$ spaced data points) reveals the presence in Hole 709B of several stratigraphic discontinuities, resulting both from loss of material between cores and repenetration of the corer. Unrecorded intervals of no recovery occur at the junction between Cores 115-709B-17H and $-18 \mathrm{H}$, and, more significantly, between Cores 115-709B-18H and $-19 \mathrm{H}$. The lengths of the sequences missing from between these cores may be gauged by reference to the WCMS profiles of the equivalent intervals in Hole 709A. These missing intervals are clearly related to the sequence repetition in Hole 709B that occurs within Core 115$709 \mathrm{~B}-18 \mathrm{H}$. The repeated sequence occurs between 163.3 and $168 \mathrm{mbsf}$ in Hole 709B and corresponds, stratigraphically, to the sequence immediately overlying it in this hole, between 158.4 and 164.5 mbsf. These stratigraphically equivalent intervals of Holes 709A and 709B are each labeled " $X$ " in Figure 16.

It is possible that the uppermost of the intervals labeled " $\mathrm{X}_{1}$ " and " $\mathrm{X}_{2}$ " in Hole 709B (Fig. 16) represents a small-scale sediment slide (lateral translation), in which the dislocated material has been redeposited en masse, thus retaining its internal stratigraphy undeformed. It is much more likely, however, that the repetition of sequence in Hole 709B is entirely attributable to repenetration of the corer. The top of the sequence in Hole 709B, labeled " $\mathrm{X}_{1}$ " in Figure 16, occurs at 158.3 mbsf, whereas the base of the sequence, labeled " $\mathrm{X}_{2}$," occurs at $168 \mathrm{mbsf}$. This interval (158.3-168 mbsf) corresponds exactly to that of Core 115-709B-18H, and the gaps in the sequence of Hole 709B between cores, as noted above, occur at the upper and lower boundaries of this core.

A possible mechanism that may account for the repetition of sequence in Hole 709B, as shown in Figure 16, is as follows. Following penetration of the APC to a depth of only about half its intended run length, the core barrel is temporarily withdrawn from the hole, unintentionally, possibly because of inadequate heave compensation during the passage of an abnormally large wave. It is then reinserted at a slight angle to the vertical into the side wall of the hole, at an immediately adjacent location to the previously cored interval, thus recoring the sequence captured by the first penetration of the corer.

Figure 17 shows a further example of sequence repetition caused by repenetration of the corer; this time, however, the repeated sequence corresponds to an entire core (115-710B-3H) and is stratigraphically equivalent to the sequence recovered during the previous coring run. The presence of a repeated sequence within, or corresponding to, Core 115-710B-3H is also indicated by the repetition of nannofossil Subzone CN14A in this core (Okada, this volume). Figure 17 also provides a further illustration of "unrecorded intervals of no recovery" between successive cores. Correlatable features in the WCMS profiles of Holes $710 \mathrm{~A}$ and $710 \mathrm{~B}$ are labeled in Figure 17, from the top of the sequence downward: P1, T1, P2, T2, and so on, according to whether the correlation point corresponds to a peak $(\mathrm{P})$ or trough $(\mathrm{T})$ in the WCMS profile of each hole. The depths at which these correlation points were identified in Holes $710 \mathrm{~A}$ and $710 \mathrm{~B}$ are listed in Table 6.

Lines of correlation between selected features of the WCMS profiles shown in Figure 17 are drawn to demonstrate that the sequence in Hole 710A between T8 and P34, that is, between $\sim 2.7$ and 13.9 mbsf (Cores 115-710A-1H and $-2 \mathrm{H}$ ), correlates with the sequence in Hole $710 \mathrm{~B}$ between $\sim 5$ and $14.4 \mathrm{mbsf}$ 


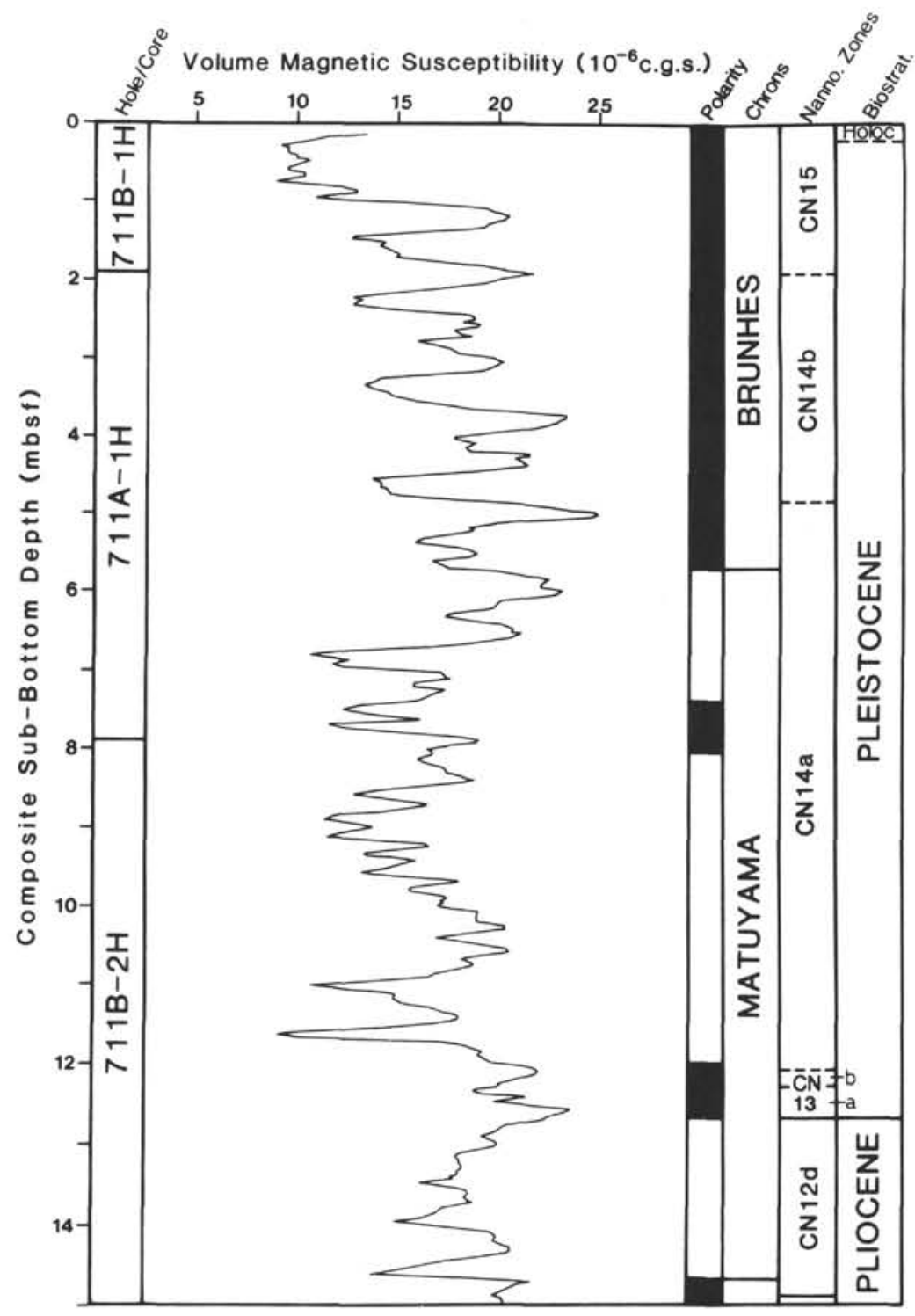

Site 711 (Composite)

Figure 12. Composite, stratigraphically continuous WCMS profile for the PliocenePleistocne sequence of Site 711 (0-15 mbsf). The composite sub-bottom depth model for Site 711 (0-40 mbsf), upon which this profile is based, is given in Table 4 .

(Cores $115-710 \mathrm{~B}-1 \mathrm{H}$ and $-2 \mathrm{H}$ ), and also with the sequence in Hole $710 \mathrm{~B}$ between 16.45 and 25.8 mbsf (Core 115-710B-3H). The interval in which the repeated sequence occurs, therefore, corresponds exactly to that of Core $115-710 \mathrm{~B}-3 \mathrm{H}$, and is stratigraphically equivalent to the sequence captured by Core 115709-2H. A small exception to this, however, is the interval labeled "X" in Figure 17, which is absent from the uppermost of the two stratigraphically equivalent sequences recovered from Hole $710 \mathrm{~B}$ because of the loss of material between Cores 115$710 \mathrm{~B}-1 \mathrm{H}$ and $-2 \mathrm{H}$. The interval labeled " $\mathrm{X}$ " is clearly identifiable in the repeated sequence in Hole 710B (Core 115-710B-3H) and in Hole $710 \mathrm{~A}$ (Core $115-710 \mathrm{~A}-1 \mathrm{H}$ ), but it is missing from between Cores $115-710 \mathrm{~B}-1 \mathrm{H}$ and $-2 \mathrm{H}$.

Figure 18 shows the correlation between the WCMS profiles of Holes 710A and 710B in the form of a Shaw Diagram, based on the data listed in Table 6 . This plot clearly illustrates the effect that repenetration of the corer has had on the stratigraphic continuity of Hole $710 \mathrm{~B}$, relative to that of Hole 710A. With the exception of two, short "unrecorded intervals of no recovery," the upper and lower segments of the single correlation curve plotted in Figure 18 lie parallel and are of equal length, indicating that the sequence in Hole $710 \mathrm{~A}$ between $\sim 2.7$ and 13.9 mbsf correlates with sequences in Hole $710 \mathrm{~B}$ both between $\sim 5$ and $14.4 \mathrm{mbsf}$, and between 16.45 and $25.8 \mathrm{mbsf}$, corresponding to Cores $115-710 \mathrm{~B}-2 \mathrm{H}$ and $-3 \mathrm{H}$, respectively.

Although Figures 17 and 18 do not show it, the repeated sequence corresponding to Core $115-710 \mathrm{~B}-3 \mathrm{H}$ was captured at the expense of the interval that should have occupied this core. This is indicated by the total absence of correlatable features between the WCMS profile of Hole 710A, for the interval between 15.5 and 23.6 mbsf, and that of Hole $710 \mathrm{~B}$ below the repeated sequence (see Backman, Duncan, et al., 1988, p. 607). Therefore, the stratigraphic sequence equivalent to that of the interval between 15.5 and $23.6 \mathrm{mbsf}$ in Hole $710 \mathrm{~A}$ is absent from the re- 
Table 4. Composite sub-bottom depth model for Site 711 to approximately $40 \mathrm{mbsf}$, based on cross-matching the WCMS profiles of Holes $711 \mathrm{~A}$ and $711 \mathrm{~B}$.

\begin{tabular}{|c|c|c|c|c|c|}
\hline \multicolumn{2}{|c|}{$\begin{array}{c}\text { Composite } \\
\text { SBD } \\
\text { (mbsf) }\end{array}$} & \multicolumn{2}{|c|}{$\begin{array}{l}\text { Depth in } \\
\text { Hole } 711 \mathrm{~A} \\
\text { (mbsf) }\end{array}$} & \multicolumn{2}{|c|}{$\begin{array}{l}\text { Depth in } \\
\text { Hole } 711 \mathrm{~B} \\
\text { (mbsf) }\end{array}$} \\
\hline Upper & Lower & Upper & Lower & Upper & Lower \\
\hline 0.00 & 0.15 & - & - & Void & Void \\
\hline 0.15 & 0.99 & - & - & 0.15 & 0.99 \\
\hline 0.99 & 1.92 & - & - & 1.17 & 2.10 \\
\hline 1.92 & 7.65 & 2.28 & 8.00 & - & - \\
\hline 7.65 & 23.36 & - & - & 4.80 & 20.51 \\
\hline 23.36 & 29.58 & 21.08 & 27.30 & - & - \\
\hline 29.58 & 40.98 & 28.53 & 39.93 & - & - \\
\hline
\end{tabular}

Note: This SBD model avoids stratigraphic discontinuities and intervals of disturbed sediment, and also excludes major turbidite horizons from the composite sequence.

cord of Hole 710B and has been replaced by the repeated sequence. Possible explanations for the coring irregularities identified at Site 710 are considered below (see "Discussion and Conclusions" section, this chapter).

\section{Contamination by Drilling Artifacts}

In several holes drilled during Leg 115 (e.g., Holes 705A, $707 \mathrm{~A}, 712 \mathrm{~A}$, and 716B), it was not possible to use WCMS profiles for correlation purposes. This was because the sediments recovered from these holes were contaminated by strongly mag netic, ferrous metal particles, such as fragments of pipe rust or similar artifacts of drilling disturbance. Contamination of this kind also affected ODP Leg 101 cores, prompting Sager (1986) to make a detailed study of the nature and distribution of metallic artifacts in these cores-using WCMS logging to identify the contaminated intervals-and to describe the probable mechanism responsible for this kind of coring disturbance. Rust-flake contamination was also a problem on ODP Leg 103, seriously disrupting the whole-core NRM records of some cores (Boillot, Winterer, Meyer, et al., 1987). Naturally, the MS values of ferromagnetic contaminants, such as rust flakes, particles of abraded drill pipe or bit, and others, are orders-of-magnitude greater than the MS values of most pelagic lithologies, with the exception of volcanic-ash-rich sediments.

Figure 19 shows the WCMS profile obtained from Hole $707 \mathrm{~A}$, to a sub-bottom depth of $100 \mathrm{~m}$. The profile consists of a series of regularly spaced, asymmetric clusters of WCMS peaks, each of which corresponds exactly to individual cored intervals of the sequence, with the culmination in WCMS peak values occurring at the top of each core. Beneath the uppermost peak or initial cluster of peaks in the WCMS profile of each core, WCMS values generally taper off downcore (the diminution often spanning a depth in core of between one-third and one-half its total length) before reaching "background" values again.

According to the mechanism proposed by Sager (1986) to explain how contamination of APC cores may occur, the uppermost peak, or cluster of peaks, in the WCMS profile of each core in Hole 707A (Fig. 19) corresponds to an interval of mechanically reworked material "washed in" from uphole, pervasively contaminated by metallic artifacts (pipe rust, etc.) scraped from the outer surface of the drill string. The gradual decline in WCMS values beneath this initial cluster of peaks, however, is merely caused by superficial smearing of pervasively contaminated material from the top of the core, around the exterior of sediment column, inside the core liner. Thus, ferrous metal contaminants may act as "tracers" (when identified by WCMS mea- surements) for intervals of mechanically reworked or slumped younger sediment from uphole.

In Figure 20, an attempt is made to discriminate between the intervals of each core in Hole 707A, between 40 and $100 \mathrm{mbsf}$, which are (1) pervasively contaminated, (2) superficially contaminated (because of smearing), or (3) uncontaminated by metallic artifacts. Shipboard lithologic descriptions of split-core sections revealed that, in most cores from Hole 707A, Section 1, and sometimes also Section 2, were highly to moderately disturbed, extremely soupy, and often contained particles of pipe rust or other metal fragments, up to $\sim 5 \mathrm{~mm}$ in length, thoroughly disseminated throughout the sediment. Below Section 1 or 2 of each core, however, the sediments were found to be generally undisturbed, though often still quite soupy (mainly because of the uncohesive nature of foraminifer-rich oozes), and metallic artifacts were observed only at the interface between the exterior of the core and the core liner. These observations are consistent with the anomalies in the WCMS profile of Hole $707 \mathrm{~A}$, and suggest-according to Sager's interpretational modelthat most, or all of Section 1, and sometimes Section 2 (or part thereof), of each core recovered from this hole consists of material washed in from uphole. This interpretation has seriously adverse implications with regard to the apparent stratigraphic continuity and accumulation rate estimates for this site.

An alternative hypothesis to explain how pervasive contamination may occur at the top of APC cores such as those from Hole $707 \mathrm{~A}$ - but one that has rather less adverse stratigraphic implications than Sager's model-is as follows. The metallic artifacts that become superficially smeared around the sediment column during penetration of the corer, could be incorporated into the sediment matrix if spontaneous liquefaction of the sediment were to occur, possibly as a result of a sudden increase to excess in pore fluid pressure caused by the initial impact of the core barrel. This effect would account for the highly disturbed and soupy condition of the core material in Section $1( \pm$ Section 2) of many cores from Hole 707A. Thus, the amount of displaced sediment washed in from uphole, and subsequently incorporated into the sequence recovered from Hole $707 \mathrm{~A}$, may be much less than is suggested by the extent of pervasive contamination of its APC cores indicated by their WCMS profiles (Fig. 20), when this is interpreted according to the mechanism proposed by Sager (1986). However, at least some washed-in sediment, containing metallic artifacts, must be present before such material can be smeared around the exterior of the sediment column during penetration of the core barrel. The mechanism proposed by Sager to account for contamination of APC cores by metallic artifacts is therefore not entirely inapplicable to the sediments recovered from Hole $707 \mathrm{~A}$, even if the alternative hypothesis outlined above is accepted. In contrast to the characteristic WCMS motif associated with pipe-rust contamination of APC cores (Fig. 20), Figure 21 shows typical WCMS anomalies resulting from contamination of rotary-drilled, $\mathrm{XCB}$ cores.

Below a depth of 174 mbsf in Hole 707A, cores were recovered using the XCB method, mainly because cherty horizons were encountered at this point in the sequence, but also because the sediments became too well indurated for APC coring. The cherty horizons proved to be extremely effective abrasive agents, not only scraping paint and rust particles from the outer surface of the drill string, but also scouring, in places, the underlying steel pipe. These metallic artifacts subsequently became incorporated into the sequence recovered from these lower horizons of Hole 707A, presumably as a result of coring "density stratified slurries" that form at the base of rotary-drilled holes, after the removal of each interval of core (Sager, 1986). Within these graded, slumped horizons, metallic artifacts tend to settle out of suspension toward the bottom of the hole. Thus, on retrieval of 


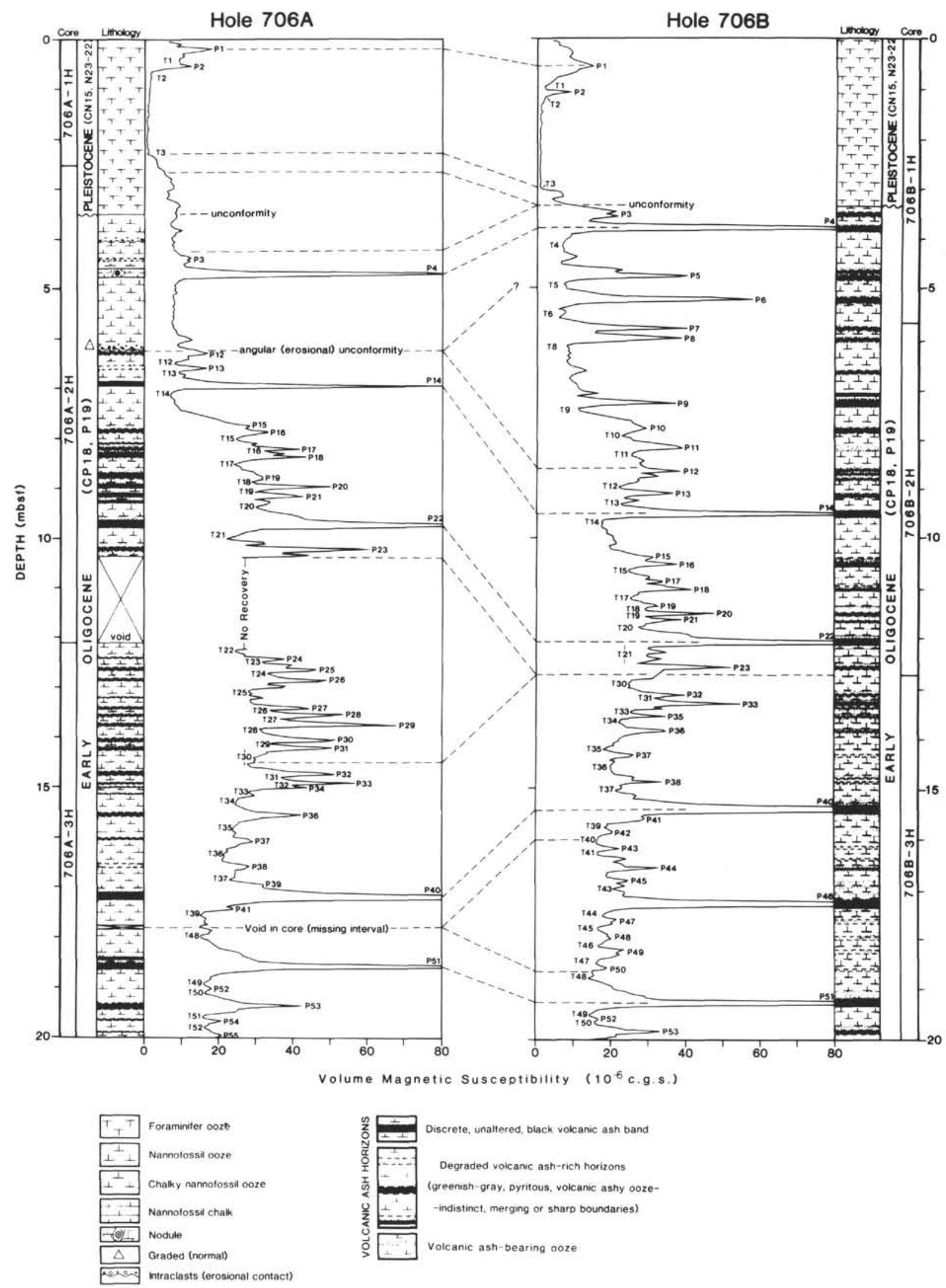

Figure 13. Tephrostratigraphic correlation between subsidiary holes drilled at Site 706, based on their WCMS profiles. Logs of volcanic-ash horizons are based on shipboard, visual core description data. The depths in each hole at which the correlation points indicated in this figure were identified are listed in Table 5. 
Table 5. Depths in Holes 706A and $706 \mathrm{~B}$ at which points of lithostratigraphic correlation between these holes were identified in Figure 13, based on cross-matching the WCMS profiles of each hole.

\begin{tabular}{|c|c|c|}
\hline $\begin{array}{c}\text { Correlation } \\
\text { point }\end{array}$ & $\begin{array}{l}\text { Depth in } \\
\text { Hole 706A } \\
\text { (mbsf) }\end{array}$ & $\begin{array}{l}\text { Depth in } \\
\text { Hole 706B } \\
\text { (mbsf) }\end{array}$ \\
\hline P1 & 0.18 & 0.53 \\
\hline $\mathrm{T} 1$ & 0.38 & 0.98 \\
\hline P2 & 0.53 & 1.08 \\
\hline $\mathrm{T} 2$ & 0.68 & 1.38 \\
\hline T3 & 2.28 & 2.98 \\
\hline Unconformity & 3.50 & 3.40 \\
\hline P3 & 4.43 & 3.52 \\
\hline P4 & 4.72 & 3.83 \\
\hline $\mathrm{T} 4$ & 4.94 & 4.16 \\
\hline P5-T11 & \multicolumn{2}{|c|}{$\begin{array}{l}\text { Missing from } 706 \mathrm{~A} \\
\text { below } \mathrm{U} / \mathrm{C} \text { at } \\
6.25\end{array}$} \\
\hline P12 & 6.31 & 8.68 \\
\hline $\mathrm{T} 12$ & 6.52 & 9.00 \\
\hline P13 & 6.61 & 9.12 \\
\hline $\mathrm{T} 13$ & 6.79 & 9.33 \\
\hline P14 & 6.97 & 9.54 \\
\hline $\mathrm{T} 14$ & 7.18 & 9.75 \\
\hline P15 & 7.75 & 10.38 \\
\hline P16 & 7.87 & 10.53 \\
\hline $\mathrm{T} 15$ & 8.02 & 10.67 \\
\hline P18 & 8.38 & 11.04 \\
\hline T17 & 8.53 & 11.22 \\
\hline P19 & 8.83 & 11.37 \\
\hline T18 & 8.88 & 11.43 \\
\hline P20 & 8.98 & 11.52 \\
\hline T19 & 9.08 & 11.58 \\
\hline P21 & 9.18 & 11.64 \\
\hline $\mathrm{T} 20$ & 9.38 & 11.79 \\
\hline P22 & 9.78 & 12.12 \\
\hline P23 & 10.24 & 12.61 \\
\hline $\mathrm{T} 22-\mathrm{T} 30$ & \multicolumn{2}{|c|}{$\begin{array}{l}\text { Missing from Hole } \\
706 \mathrm{~B}\end{array}$} \\
\hline P32 & 14.75 & 13.15 \\
\hline T31 & 14.81 & 13.21 \\
\hline P33 & 14.93 & 13.33 \\
\hline P34 & 15.02 & 13.42 \\
\hline
\end{tabular}

the next interval of core, the contaminants tend to be concentrated in a discrete horizon at the base of a spurious graded bed at the top of the core. The resulting WCMS profile of these horizons characteristically displays a prominent peak, or cluster of peaks, corresponding to the base of the slump, with WCMS values tapering off uphole (Fig. 21). This directly opposes the trend in WCMS anomalies associated with drilling contamination of APC cores (Fig. 20). Considerable smearing of contaminated material, both above and below the base of the slumped horizon, may also occur during XCB coring-in fact, more so than with APC coring, because rotary drilling generally causes much greater disturbance of the sediment. However, smearing of contaminated material does not appear to have occurred below the bases of the slumped horizons in Hole 707A, as indicated by the sharp drop in WCMS values that marks the base of these horizons in this hole (Fig. 21).

\section{Identification of Early Diagenesis}

As noted above, in several holes drilled during Leg 115, an interval of "reduced" sediment (i.e., one in which pore waters had become anoxic postdepositionally) was encountered that, in CDP sites, proved to be of late Miocene to uppermost Pliocene or very early Pleistocene age (see Fig. 15). The sediments that constitute this interval generally accumulated more rapidly than those deposited immediately above and below it in the sequences
Table 5 (continued).

\begin{tabular}{|c|c|c|}
\hline $\begin{array}{c}\text { Correlation } \\
\text { point }\end{array}$ & $\begin{array}{l}\text { Depth in } \\
\text { Hole 706A } \\
\text { (mbsf) }\end{array}$ & $\begin{array}{l}\text { Depth in } \\
\text { Hole 706B } \\
\text { (mbsf) }\end{array}$ \\
\hline $\mathrm{T} 33$ & 15.11 & 13.48 \\
\hline P35 & 15.17 & 13.57 \\
\hline T34 & 15.35 & 13.69 \\
\hline P36 & 15.56 & 13.87 \\
\hline T35 & 15.98 & 14.23 \\
\hline P37 & 16.10 & 14.35 \\
\hline T36 & 16.25 & 14.44 \\
\hline P38 & 16.58 & 14.89 \\
\hline T37 & 16.85 & 15.04 \\
\hline P39 & 16.97 & 15.16 \\
\hline T38 & 17.00 & 15.22 \\
\hline $\mathrm{P} 40$ & 17.21 & 15.46 \\
\hline P41 & 17.45 & 15.61 \\
\hline T39 & 17.57 & 15.79 \\
\hline T40-P50 & \multicolumn{2}{|c|}{$\begin{array}{l}\text { Missing from Hole } \\
706 \mathrm{~A}\end{array}$} \\
\hline T48 & 17.99 & 18.79 \\
\hline P51 & 18.59 & 19.27 \\
\hline T49 & 18.92 & 19.51 \\
\hline P52 & 19.03 & 19.60 \\
\hline T50 & 19.13 & 19.66 \\
\hline P53 & 19.37 & 19.84 \\
\hline P54 & 19.67 & 20.08 \\
\hline T52 & 19.79 & 20.17 \\
\hline P55 & 19.97 & 20.29 \\
\hline T53 & 20.06 & 20.44 \\
\hline P56 & 20.15 & 20.72 \\
\hline T54 & 20.43 & 20.87 \\
\hline T56 & 22.23 & 22.27 \\
\hline T57 & 22.35 & 22.16 \\
\hline $\mathrm{P} 60$ & 22.47 & 22.25 \\
\hline P61 & 25.92 & 27.18 \\
\hline P62 & 26.52 & 28.13 \\
\hline T58 & 26.76 & 28.23 \\
\hline $\mathrm{P} 63$ & 26.88 & 28.28 \\
\hline P64 & 27.24 & 28.73 \\
\hline P65 & 27.69 & 29.03 \\
\hline T59 & 27.78 & 29.08 \\
\hline P66 & 27.93 & 29.16 \\
\hline T60 & 28.02 & 29.23 \\
\hline P67 & 28.41 & 29.58 \\
\hline
\end{tabular}

recovered, but were otherwise compositionally indistinguishable. However, the reduced interval was classified as a distinct lithologic subunit of most holes in which it was recognized, principally on the basis of its characteristic gray, or greenish gray colors. The brown-green (white-gray) color change associated with reduction in deep-sea sediment sequences is thought to be caused by a transition from $\mathrm{Fe}$ (III) to $\mathrm{Fe}(\mathrm{II})$ as the stable form of structural iron in clay mineral lattices, particularly smectite (Lyle, 1983). Naturally, this change in the stability of iron-bearing phases in the sediment with respect to $\mathrm{Eh}$, will be reflected in its MS values, since most of the strongly magnetic minerals in deep-sea sediments are iron oxides or oxyhydroxides (see "Magnetic Susceptibility: Definition and Interpretation" section, this chapter).

In most pelagic environments, sediment accumulation rates are low enough to ensure that more than $90 \%$ of all organic detritus deposited is remineralized syndepositionally, utilizing $\mathrm{O}_{2}$ freely available in the well-oxygenated intermediate and deep waters of the oceans (Bender and Heggie, 1984). The small proportion of organic matter that remains can usually be oxidized within the top $\sim 0.5-1.0 \mathrm{~m}$ of the sequence, via interstitial diffusion of $\mathrm{O}_{2}$ from the overlying sea water (Wilson et al., 1985; Thompson et al., 1987). These are the conditions for accumulation of "oxic" sediments (Berner, 1981).

The establishment of reducing conditions in deep-sea sediments, therefore, is usually associated with (1) abnormally high 


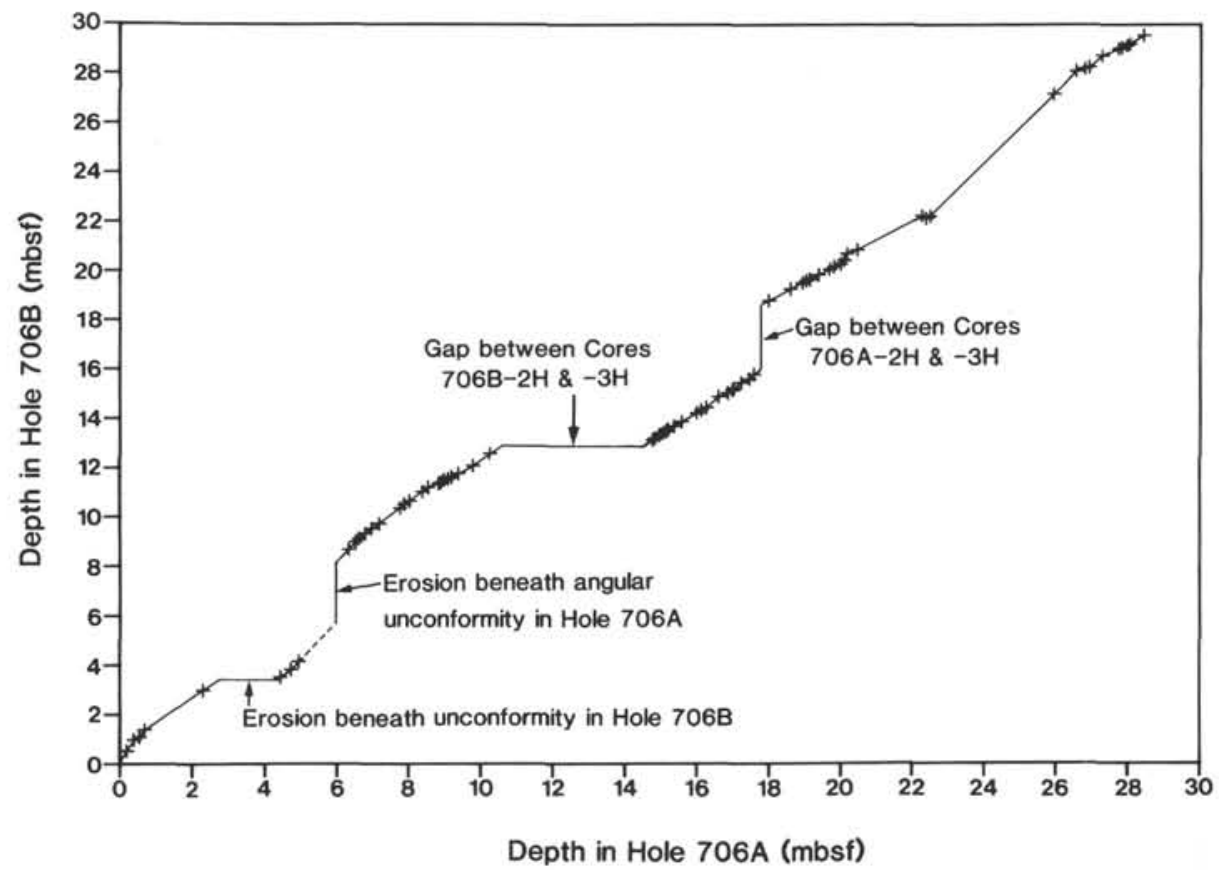

Figure 14. Shaw Diagram correlating depth in Hole 706A with depth in Hole 706B, based on crossmatching the WCMS profiles of each hole (Fig. 13). The data used to construct this plot are listed in Table 5.

rates of organic matter production and deposition (e.g. in upwelling areas), and/or (2) restricted circulation, and thus deoxygenation, of bottom waters (Arthur et al., 1984). These factors favor the retention of unoxidized organic detritus in the sediment postdeposition. This leads to depletion of pore-water $\mathrm{O}_{2}$ and the development of bacterially mediated processes of suboxic diagenesis of organic matter in the sediment (Froelich et al., 1979). These processes involve ionic dissociation of solidphase oxides by different populations of reducing bacteria (electron donors), thus releasing secondary oxidants for continued remineralization of organic detritus in the sediment. Ideally, following depletion of pore water $\mathrm{O}_{2}$, suboxic organic matter diagenesis proceeds by reduction (bacterial dissociation) of nitrates, then Mn oxides, Fe oxides (and oxyhydroxides), and lastly sulfates, before progressing ultimately to methanogenesis (Karlin and Levi, 1985). The sequence of reactions may be interrupted at any stage, depending on the amount of organic matter and availability of secondary oxidants in the sediment. Clearly, the "dissolution" (reduction or bacterial dissociation) of magnetic iron and manganese oxides or oxyhydroxides during suboxic diagenesis in deep-sea sediments will significantly decrease their MS and magnetic remanence values.

Following the stages of iron oxide and sulfate reduction during suboxic diagenesis, Fe(II) ions dissociated from detrital (titano)magnetite (ferrimagnetic) grains originally in the sediment, may react with dissolved sulfide $\left(\mathrm{H}_{2} \mathrm{~S}\right)$ in pore waters, thus forming the much more weakly magnetizable (paramagnetic) mineral pyrite $\left(\mathrm{FeS}_{2}\right)$ (Canfield and Berner, 1987). Occasionally, under rather more restricted $\mathrm{Eh}, \mathrm{Ph}$ and $\mathrm{pS}^{2-}$ conditions, the more strongly magnetic (ferrimagnetic) mineral pyrrhotite $\left(\mathrm{Fe}_{x} \mathrm{~S}_{1-x}\right.$, where $x=0-0.13$ ) may be formed (e.g., Kobayashi and Nomura, 1974; Sheu and Presley, 1986). Precipitation of authigenic pyrite (or pyrrhotite), following suboxic organic matter diagenesis, is also bacterially mediated (Curtis, 1983), with the resulting crystals of pyrite often exhibiting framboidal morphology.

During shipboard examination of split-core sections on Leg 115 , frequent observations were made of discrete pyrite crystals or "pyritous staining" in the reduced intervals of many of the holes drilled during the leg (i.e., at Sites 706 through 711, and 713 through 716 ). Pyrite crystals were most abundant in degraded volcanic-ash horizons, most notably at Site 706 (see Fig. 13 and accompanying text) where some were in the form of framboidal microspheres. Also, many pale green laminae were observed in the calcareous ooze sequences recovered during Leg 115 that were thought to result from pyrite staining. In previous studies (e.g., Gardner et al., 1986), such pale green laminae in calcareous oozes were attributed to the degradation of volcanic ash. Therefore, in all Leg 115 holes where intervals of reduced sediment were encountered, there is ample evidence to suggest that suboxic processes of organic matter diagenesis have been responsible for the observed changes in sediment color and mineralogy, and that these processes have progressed further than the stages of iron oxide and sulfate reduction. The strong odor of hydrogen sulfide effused when cores from the shallow Maldive sites (Sites 714 and 716) were split further attests to the advanced stage reached in the sequence of suboxic reactions associated with organic matter diagenesis at these sites.

All of the reduced intervals in Leg 115 holes, therefore, were associated with anomalously low WCMS values (e.g., Fig. 15). In this context, "anomalously low" WCMS values refer to ones that are consistently lower than the values predicted by the WCMS-carbonate content relationship for these holes above and below the reduced interval. A good example of this effect is shown in Figure 4, where WCMS values within the reduced interval of Hole 710A (lithologic Subunit IB) do not appear to be significantly lower than elsewhere in the profile. However, when the WCMS profile of this hole is compared with its record of carbonate content variations, the strong, inverse relationship between these two parameters above and below the reduced interval is clearly not maintained within it.

Figures 22 and 23 show the effects of early diagenesis on the WCMS record at Site 709. In Figure 22 the WCMS profiles of Holes $709 \mathrm{~A}$ and $709 \mathrm{C}$, between 0 and $140 \mathrm{mbsf}$, are plotted alongside the lithologic units and biostratigraphic subdivision 
Volume Magnetic Susceptibility $\left(10^{-6}\right.$ c.g.s.)

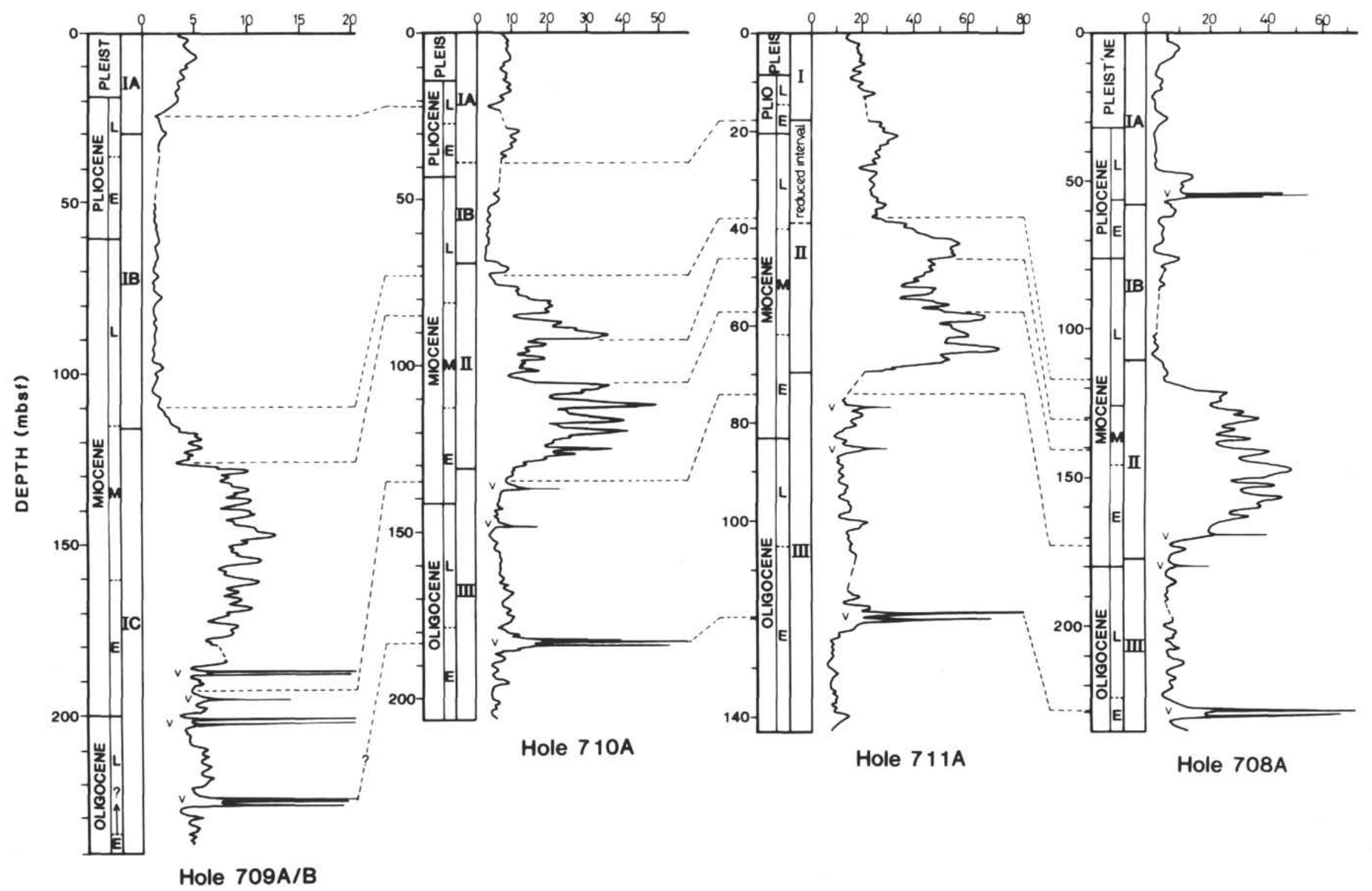

Figure 15. Regional scale lithostratigraphic correlation between holes drilled at Sites 708, 709, 710, and 711, based on simplified (10-point moving average, turbidite-free) WCMS profiles of each 


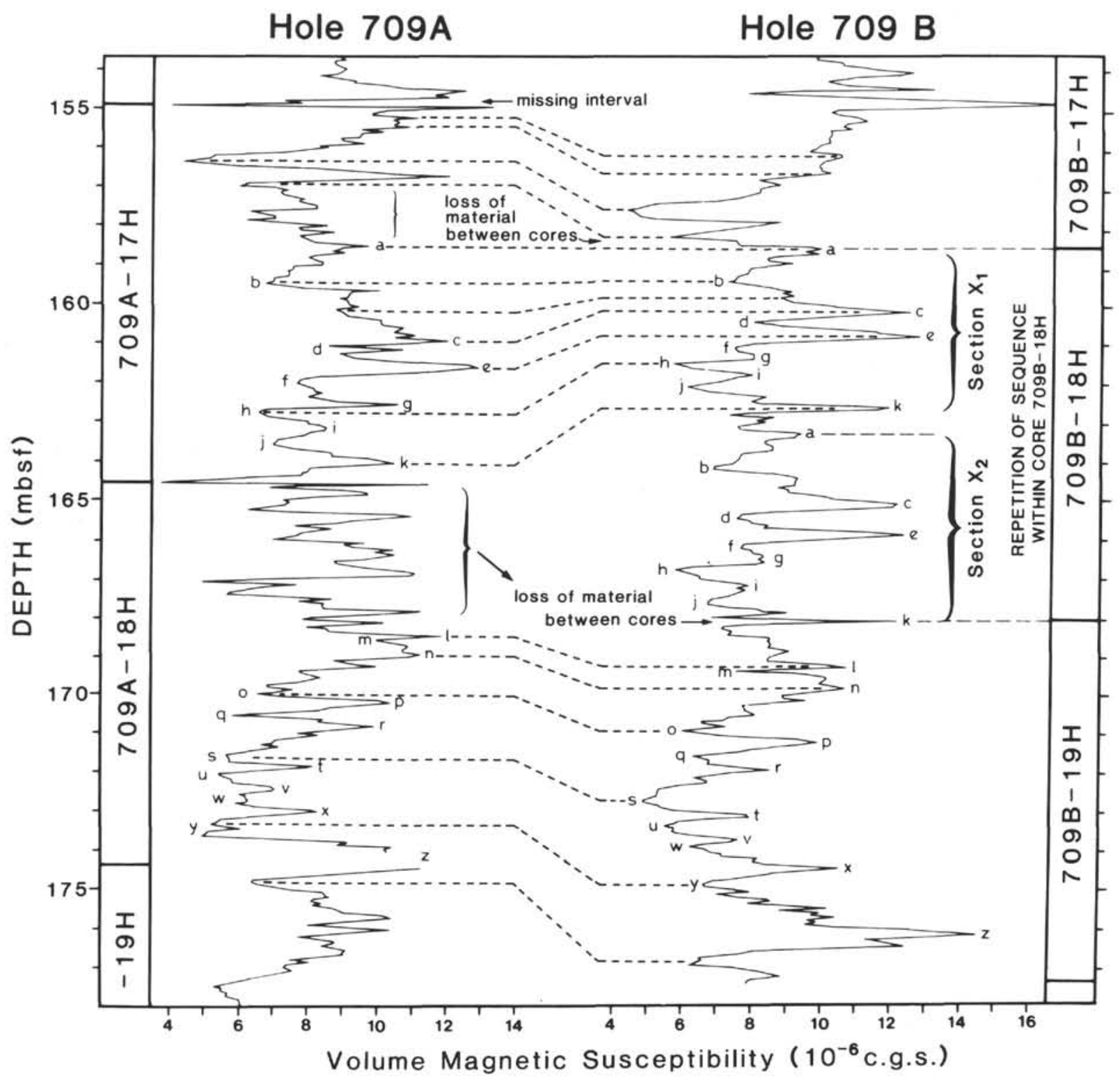

Figure 16. Lithostratigraphic correlation between Holes 709A and 709B for the interval between 153.5 and 178 mbsf (early Miocene), based on WCMS profiles of each hole. Letter-coded WCMS peaks indicate points of auto- and cross-correlation within and between each hole.

of the sequence at this site. Lithologic units were subdivided largely on the basis of sediment colors, which changed from white or brown hues in Subunit IA, to grey or green hues in Subunit IB, indicating that sediments of the latter unit had become anoxic postdepositionally. Clearly, throughout the interval of reduced sediment in Holes 709A and 709C (i.e., lithologic Subunit IB), the WCMS signal-to-noise ratio barely rises above unity (except in volcanic-ash-rich horizons), suggesting that magnetic iron oxides and oxyhydroxides in this interval have been depleted to virtually undetectable concentrations by the effects of suboxic diagenesis. WCMS values begin to fall, because of reduction, at around the middle to late Miocene boundary $(\sim 118$ mbsf), and remain consistently low-close to the detection limit of the WCMS sensor-throughout the late Miocene and most of the Pliocene ( $\sim 118$ through $22.5 \mathrm{mbsf}$ ). WCMS values then begin to rise again toward the Pliocene/Pleistocene boundary $(\sim 20$ mbsf), and above this, the sediments are unaffected by early diagenesis. Figure 23 shows very clearly that the WCMS values for the reduced interval (Subunit IB) of Hole 709A are "anomalously low" in relation to the carbonate content of the sediment in these horizons.

Figure 23 plots the relationship between WCMS and carbonate content (shipboard "Geochemistry" data) in Hole 709A, for the interval of this hole shown in Figure $22(0-140 \mathrm{mbsf})$. Data from horizons above and below the reduced interval of this hole (i.e., lithologic Subunits IA and IC) are denoted by the squares plotted in Figure 23, whereas data from the reduced interval (Subunit IB) are plotted as triangles. The relationship between WCMS and carbonate content data from the oxic horizons of this hole (squares) is essentially the same as that depicted in Figure $5 \mathrm{C}$, where the correlation coefficient for this relationship (Sites 709 and 711 combined) was $r=0.990$. Data from the reduced interval of Hole 709A (triangles) clearly plot in an entirely separate field of the graph shown in Figure 23, to the data 


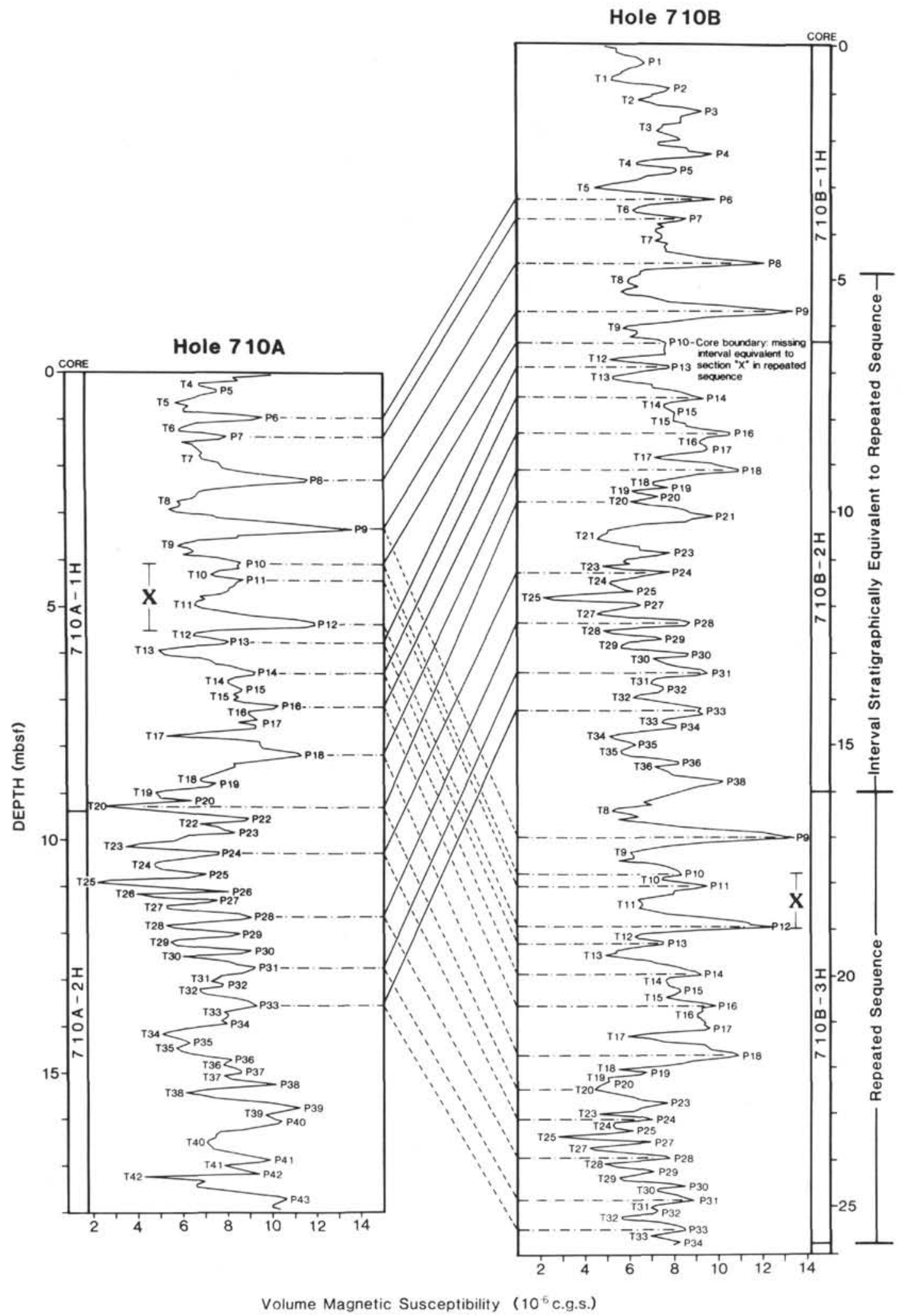

Figure 17. WCMS-based, lithostratigraphic correlation between the Pleistocene horizons of Holes 710A and 710B, showing the sequence repetition in Hole $710 \mathrm{~B}$ corresponding to the entire length of Core $115-710 \mathrm{~B}-2 \mathrm{H}$. The depths in each hole at which the correlation points indicated in this figure were identified are listed in Table 6. 
Table 6. Depths in Holes 710A and 710B at which points of lithostratigraphic correlation between these holes were identified in Figure 17, based on cross-matching the WCMS profiles of each hole.

\begin{tabular}{|c|c|c|c|c|c|}
\hline $\begin{array}{l}\text { Correlation } \\
\text { point }\end{array}$ & $\begin{array}{l}\text { Depth in } \\
\text { Hole } 710 \mathrm{~A} \\
\text { (mbsf) }\end{array}$ & $\begin{array}{c}\text { Depths in } \\
\text { Hole } 710 \mathrm{~B} \\
\text { (mbsf) }\end{array}$ & $\begin{array}{c}\text { Correlation } \\
\text { point }\end{array}$ & $\begin{array}{l}\text { Depth in } \\
\text { Hole } 710 \mathrm{~A} \\
\text { (mbsf) }\end{array}$ & $\begin{array}{l}\text { Depths in } \\
\text { Hole } 710 \mathrm{~B} \\
\text { (mbsf) }\end{array}$ \\
\hline \multirow[t]{2}{*}{ P1-P4 } & \multirow{2}{*}{\multicolumn{2}{|c|}{$\begin{array}{l}\text { Missing from Hole } \\
710 \mathrm{~A}\end{array}$}} & P23 & 9.81 & $10.89,22.70$ \\
\hline & & & $\mathrm{T} 23$ & 10.14 & $11.15,22.95$ \\
\hline $\mathrm{T} 4$ & 0.24 & 2.54 & P24 & 10.30 & $11.29,23.08$ \\
\hline P5 & 0.40 & 2.67 & $\mathrm{~T} 24$ & 10.54 & $11.50,23.20$ \\
\hline T5 & 0.65 & 3.04 & P25 & 10.75 & $11.70,23.30$ \\
\hline P6 & 0.95 & 3.30 & $\mathrm{~T} 25$ & 10.90 & $11.83,23.44$ \\
\hline T6 & 1.23 & 3.51 & P26 & 11.08 & $-\quad-$ \\
\hline P7 & 1.38 & 3.74 & T26 & 11.16 & $11.83,23.44$ \\
\hline T7 & 1.78 & 4.16 & P27 & 11.30 & $11.99,23.57$ \\
\hline P8 & 2.27 & 4.63 & $\mathrm{~T} 27$ & 11.43 & $12.16,23.70$ \\
\hline T8 & 2.73 & $5.01,16.40$ & P28 & 11.65 & $12.36,23.89$ \\
\hline P9 & 3.31 & $5.72,16.99$ & T28 & 11.83 & $12.55,24.06$ \\
\hline T9 & 3.68 & $6.02,17.36$ & P29 & 12.02 & $12.71,24.19$ \\
\hline P10 & 4.06 & $6.34,17.78$ & $\mathrm{~T} 29$ & 12.19 & $12.88,24.37$ \\
\hline $\mathrm{T} 10$ & 4.28 & $-\quad 17.89$ & P30 & 12.38 & $13.04,24.51$ \\
\hline P11 & 4.43 & $-\quad 18.04$ & T30 & 12.49 & $13.15,24.60$ \\
\hline T11 & 4.88 & $-\quad 18.43$ & P31 & 12.74 & $13.44,24.80$ \\
\hline P12 & 5.34 & $6.34,18.85$ & T31 & 12.99 & $13.66,24.98$ \\
\hline $\mathrm{T} 12$ & 5.58 & $6.70,19.11$ & P32 & 13.09 & $13.79,25.07$ \\
\hline P13 & 5.76 & $6.88,19.27$ & $\mathrm{~T} 32$ & 13.22 & $13.97,25.19$ \\
\hline T13 & 5.99 & $7.10,19.50$ & P33 & 13.53 & $14.29,25.45$ \\
\hline P14 & 6.44 & $7.57,19.93$ & T33 & 13.67 & $14.50,25.60$ \\
\hline T14 & 6.60 & $7.73,20.11$ & P34 & 13.82 & $14.60,25.75$ \\
\hline P15 & 6.79 & $7.90,20.29$ & T34 & 14.15 & 14.80 \\
\hline $\mathrm{T} 15$ & 6.89 & $8.00,20.42$ & P35 & 14.32 & 15.99 \\
\hline P16 & 7.14 & $8.30,20.60$ & T35 & 14.44 & 15.14 \\
\hline T16 & 7.26 & $8.50,20.84$ & P36 & 14.69 & 15.39 \\
\hline P17 & 7.51 & $8.64,21.08$ & T36 & 14.80 & 15.48 \\
\hline $\mathrm{T} 17$ & 7.75 & $8.80,21.28$ & P37 & 14.96 & - \\
\hline P18 & 8.16 & $9.10,21.68$ & T37 & 15.05 & - \\
\hline T18 & 8.71 & $9.39,22.00$ & P38 & 15.20 & 15.80 \\
\hline P19 & 8.81 & $9.45,22.10$ & & & Top of \\
\hline T19 & 9.03 & $9.58,22.20$ & & & repeated \\
\hline P20 & 9.15 & $9.65,22.25$ & & & sequence \\
\hline $\mathrm{T} 20$ & 9.28 & $9.79,22.42$ & & & (see T8) \\
\hline P21 & - & $10.09-$ & & & \\
\hline $\mathrm{T} 21$ & - & 10.55 & Note: $\mathrm{P}=$ & WCMS pea & $\mathrm{k}$ and $\mathrm{T}=$ \\
\hline P22 & 9.54 & $-\quad-$ & trough. & & \\
\hline $\mathrm{T} 22$ & 9.66 & $10.55,22.42$ & & & \\
\hline
\end{tabular}

from the oxic horizons (squares), despite there being no significant difference in the distribution of carbonate content values between each group. The WCMS values of the anoxic group of samples (triangles) appear to be totally independent of carbonate variations, suggesting that the WCMS signal of sediments deposited at this site derives from a low concentration of a strongly magnetic (ferrimagnetic) iron oxide, which has now been replaced by a similar (or lower) concentration of a nonmagnetic (paramagnetic) and thus more weakly magnetizable form of reduced iron in the sediment.

At Site 709 and at other CDP sites, the interval of reduced sediment is associated with slightly higher than average bulk sedimentation rates for the site, and also with a higher proportion of biogenic silica in the sediment. These additional characteristics of the anoxic interval of CDP holes may provide valuable clues as to its possible causes. These are discussed below (see "Discussion and Conclusions" section, this chapter).

\section{Paleoclimatic Investigations}

Since WCMS often reflects the ratio of biogenic to lithogenic components in deep-sea sediments, in many instances it may also reflect their paleoclimatic record in view of the well-established relationship between fluctuations in the carbonate content of deep-sea sediments and climatic changes (e.g., Olausson, 1967; Broecker, 1971; Berger, 1973; Ramsay, 1974; Volat et al., 1980; Crowley, 1985; Dean and Gardner, 1986; Rea et al., 1986; Chuey et al., 1987). The carbonate content of deep-sea sediments may be regulated by climatic influences by one or more of the following three mechanisms: (1) dilution of the biogenic carbonate fraction of the sediment by terrigenous detritus, preferentially during glacial periods; (2) dissolution of carbonate constituents of the sediment by seawater undersaturated with respect to $\mathrm{CaCO}_{3}\left(\mathrm{Ca}^{2+}\right.$ and $\mathrm{HCO}_{3}{ }^{-}$ions), as a result of CCD fluctuations; and (3) productivity variations of carbonatesecreting flora and fauna. The interrelationship among carbonate content, magnetic mineral concentration, and paleoclimatic records of deep-sea sediments has prompted several workers in recent years to use MS and related rock magnetic parameters, like IRM and ARM, as proxy paleoclimatic indexes (e.g., Kent, 1982; Robinson, 1982; Robinson and Bloemendal, 1983; Oldfield and Robinson, 1985; Mead et al., 1986; Robinson, 1986a, 1986b; Thompson and Oldfield, 1986, p. 145; Bloemendal et al., 1988).

Figure 6 demonstrates the application of WCMS logging as a tool for investigating the paleoclimatic record of Quaternary deep-sea sediments, in which carbonate fluctuations are controlled mainly by dilution of the biogenic fraction of the sediment by ice-rafted terrigenous detritus during glacial periods (Kidd et al., 1983). Glacial horizons of these cores may therefore be distinguished from interglacial horizons by their generally higher WCMS values, whereas individual peaks in WCMS within glacial horizons correlate with regional (North Atlantic) ice-rafting episodes (e.g., Heinrich, 1988) as well as with more widely recognized (stadial) paleoclimatic events (e.g. isotopic events $2.22,2.24,3.2,4.2,6.2$, and 6.4; defined by Prell et al., 1986). The cores were collected from an area that lies well above the CCD and present-day sedimentary lysocline (cf. DSDP Site 608 ); thus, dissolution of carbonate constituents in these sediments is minimal. During glacial episodes, however, the North Atlantic Polar Front migrated south to within $3^{\circ}$ of latitude north of the area, resulting in a considerable drop in sea-surface temperature and salinity, thus decreasing carbonate productivity (especially coccoliths) as well as introducing a major flux of terrigenous detritus by ice-rafting (Ruddiman and McIntyre, 1976). Robinson (1986a, 1986b) also identified a quantitatively small, but magnetically significant, eolian component in these cores, concentrations of which vary directly in proportion to the paleoclimatic records, but independently of carbonate fluctuations.

Thus, several climatically controlled mechanisms of magnetic mineral deposition, dilution, or concentration have been responsible for the observed paleoclimatic signal inherent in the WCMS records of the KTF cores (Fig. 6). The dominant, inphase, paleoclimatic control of magnetic concentration in the KTF cores is also demonstrated by the relationship between WCMS variations and their own oxygen isotope records (Robinson, 1986a, 1986b), upon which the stages shown in Figure 6 are based. Also, intervals labeled "glacial" and "interglacial" in Figure 6 are based on detailed analysis of the entire planktonic foraminifer assemblage in these cores (see Weaver, 1983).

In contrast to the paleoclimatic signal in deep-sea sediment WCMS profiles imparted by the mechanisms of carbonate dilution and/or productivity variations, Figures 3 and 12 show the effects of periodic fluctuations in carbonate dissolution-largely modulated by orbital forcing-on the \%-carbonate and WCMS records of Site 711. Figure 3 shows that WCMS variations in Core 115-711A-1H, of middle to uppermost Pleistocene age, are strongly related $(r=0.971)$ to dissolution-controlled oscillations in carbonate content of the sediment. The time scale indicated in this figure is based on nannofossil datums identified by Okada (this volume) and the shipboard magnetic reversal stratigraphy for this core. The positions at which oxygen isotope stage boundaries shown in Figure 3 were interpolated, are based on the SPECMAP ages for these events listed in Imbrie et al. 


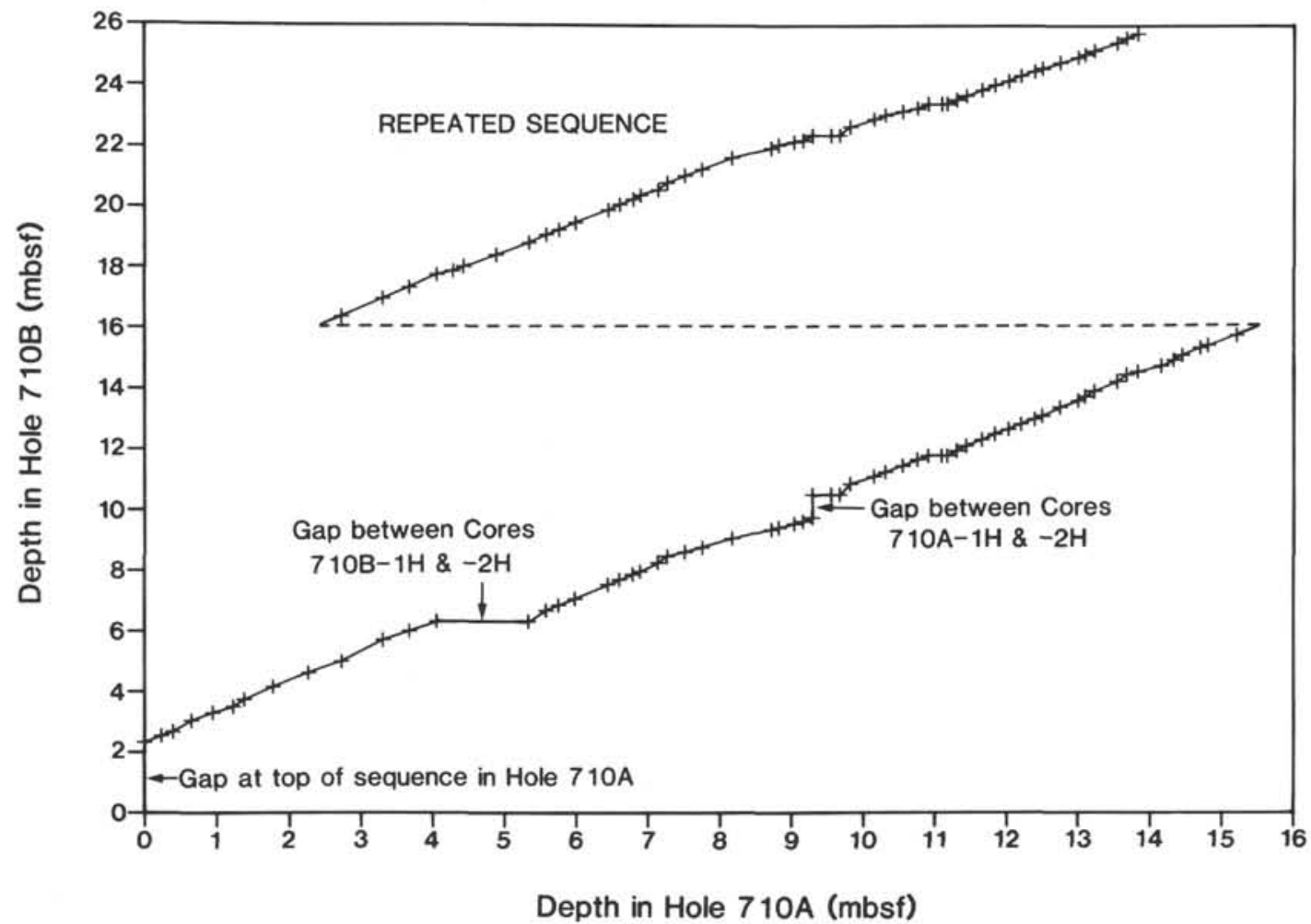

Figure 18. Shaw Diagram correlating depth in Hole 710A with depth in Hole 710B, based on cross-matching the WCMS profiles of each hole (Fig. 17). The data used to construct this plot are listed in Table 6 .

(1984). Direct oxygen isotope measurements on individual foraminifer species in this core were precluded by the effects of severe dissolution. Bulk oxygen and carbon isotope measurements were made on 103 samples from Core $115-711 \mathrm{~A}-1 \mathrm{H}$, but the results proved to be unusable for stratigraphic purposes and are therefore not reproduced here.

Fluctuations in the \%-carbonate and WCMS records of Core 115-711A-1H appear to exhibit a dominant, near-100-k.y. periodicity, corresponding to that of the Earth's orbital eccentricity cycle (e.g., Hays et al., 1976; Imbrie and Imbrie, 1980; Imbrie et al., 1984). This apparent periodicity is suggested by the approximate correlation between WCMS and \%-carbonate half cycles and most isotopic stages, and the fact that seven complete cycles in the downcore records of these parameters occur between the Brunhes/Matuyama boundary and isotopic stage 5a highly characteristic feature of $100-k$.y.-dominated records of paleoclimatic indexes for late Quaternary deep-sea sediments (Jenkins et al., 1985).

To test more rigorously the hypothesis that cyclicity in the WCMS and \% -carbonate records of Site 711 is orbitally forced, spectral analysis was performed on the composite WCMS profile data for this site, as shown in Figure 12. That this composite profile effectively mirrors carbonate content of the sediment has already been noted above with reference to Figure 3 . The Site 711 composite WCMS profile, therefore, represents a continuous, proxy-carbonate record for the entire Quaternary, with stratigraphic discontinuities and intervals of disturbed sediment (e.g., the top $40 \mathrm{~cm}$ of Core $115-711 \mathrm{~A}-1 \mathrm{H}$ ) avoided, and turbidite horizons removed from the sequence. The age model used for spectral analysis of this composite WCMS profile was based on shipboard paleomagnetic and biostratigraphic datums (Backman, Duncan, et al., 1988, p. 674), with further time control points given by the nine Quaternary nannofossil datums identified by Okada (this volume). Before beginning spectral analysis, WCMS data-originally spaced at $3-\mathrm{cm}$ intervals downcorewere recalculated, by linear interpolation, at equally spaced time increments of 5 k.y. This sample time interval yields Nyquist periods (the shortest period that can be resolved by spectral analysis) from about 10 to 14 k.y. for the interpolated WCMS time series. The procedures followed for spectral analysis of this time series are detailed by Jenkins and Watts (1968, pp. 209-257). The results of this analysis are shown in Figure 24 , in the form of two logarithmic variance-density spectra: Figure $24 \mathrm{~A}$, corresponding to the middle and upper Pleistocene interval of the time series, that is, between $0.92 \mathrm{Ma}$ and $\sim 0.015$ $\mathrm{Ma}$ (7.5-0.15 mbsf); and Figure 24B, corresponding to the middle and lower Pleistocene interval of the same sequence, that is, between $0.82 \mathrm{Ma}$ and $1.87 \mathrm{Ma}$ (6.5-12.6 mbsf). Spectral analysis of the upper and lower portions of the composite WCMS time series for Site 711 was performed separately because the dominant frequency of WCMS cycles at this site clearly changes within the interval between the Brunhes/Matuyama and top-Jaramillo magnetic reversal boundaries (see Fig. 12). Above this transition, near-100-k.y. cycles appear to dominate the WCMS record, whereas below the transition, WCMS variations exhibit a more complex pattern of spectral components.

Figure 24A reveals that, for the middle and upper Pleistocene sequence at Site 711, variance in WCMS is concentrated at several periods that approximate all of the dominant cycles in the Milankovitch band (i.e., 413- and 100-k.y. eccentricity cycles; a 41-k.y. obliquity cycle; and 23- and 19-k.y. precessional cycles; see Imbrie, 1985), particularly at around 100 k.y., but also at two anomalous periods: 71 and $36 \mathrm{k} . \mathrm{y}$. It is possible that 


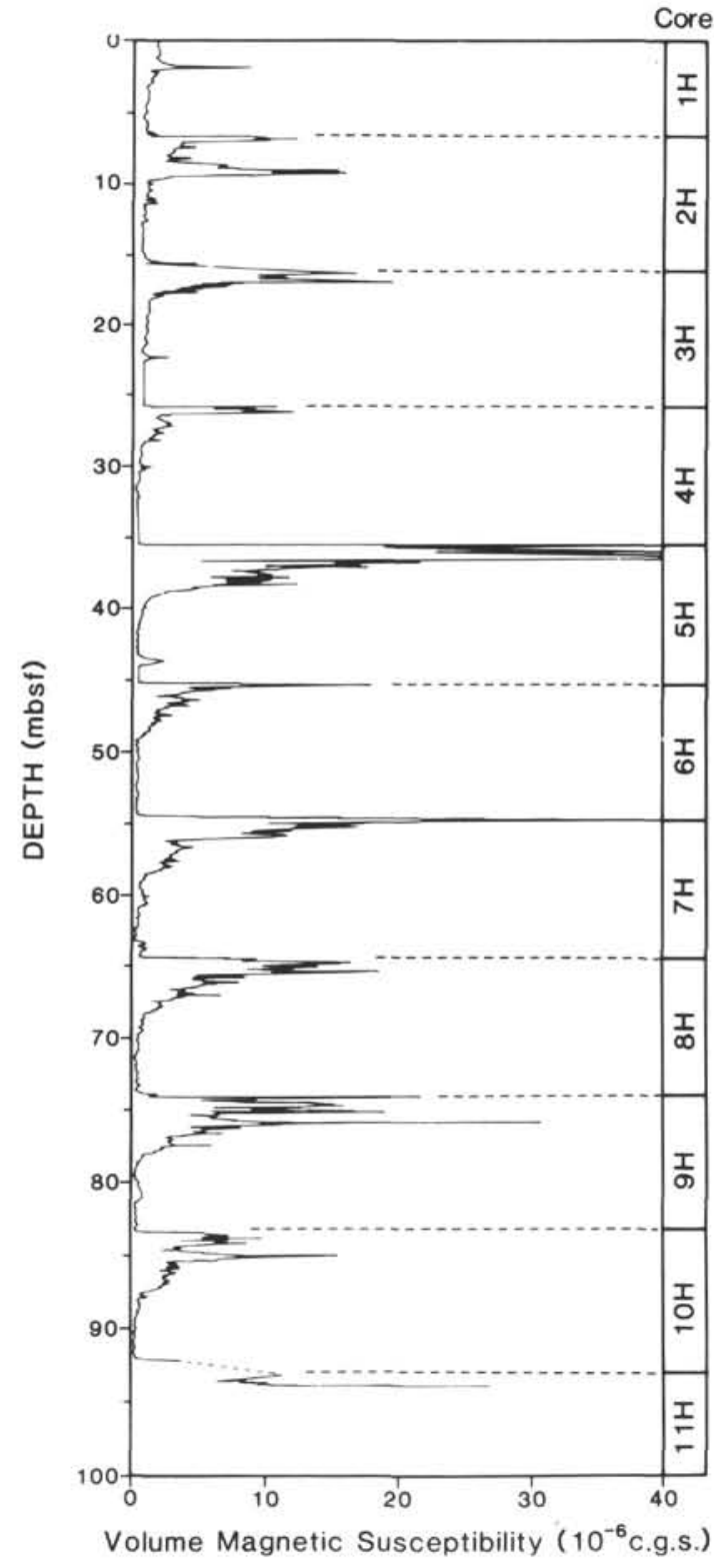

Figure 19. WCMS profile of Hole 707A to 100 mbsf, showing the correspodence between WCMS peaks and individual cored intervals of the sequence, caused by contamination by ferrous metal artifacts (e.g., pipe rust) at the top of each core that resulted from drilling disturbance.

these, and other conspicuous peaks in this spectrum that do not correspond to primary Milankovitch responses, may represent heterodyne tones at harmonics, or possibly combination tonesone of which is known to occur at a period of $69 \mathrm{k} . \mathrm{y}$., which is close to the 71-k.y. spectral peak in Figure 24A. Combination tones reflect nonlinear interactions between pairs of the primary Milankovitch responses (Ghil, 1987). However, with regard to the anomalous 36-k.y. peak, Morley and Hays (1978) identified a period of about 37.5 k.y. for variations in carbonate content of a core from the subtropical Atlantic. It is also possible, of course, that the anomalous 71- and 36-k.y. periods in the spectrum of WCMS variations for the middle and upper Pleistocene sequence of Site 711 simply represent some other influence on carbonate accumulation that is not modulated by orbital forcing in the Milankovitch band.

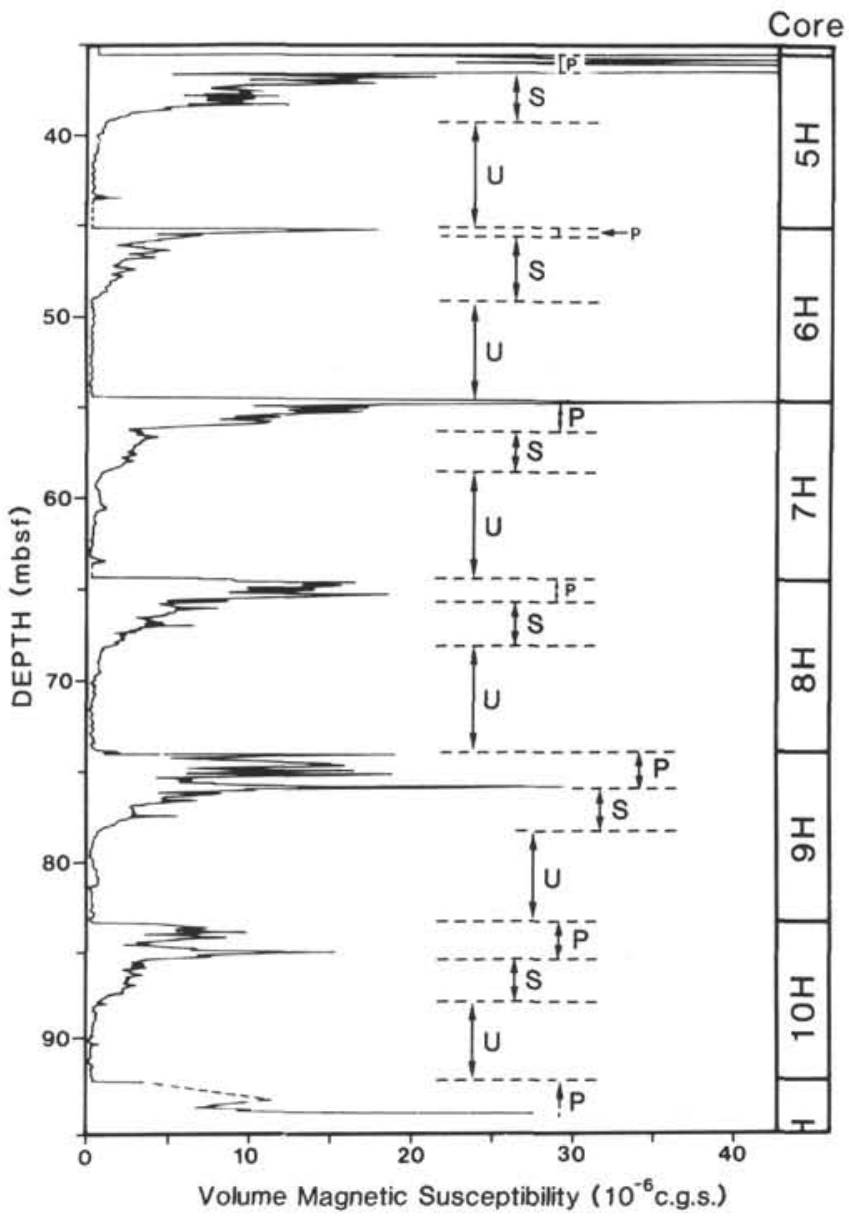

Figure 20. WCMS profile of a subsection from Hole 707A, between 40 and 100 mbsf, showing the characteristic "sawtooth" motif associated with contamination by ferrous metal artifacts at the top of APC cores, and the subsequent smearing of these contaminants around the exterior of the sediment column (inside the core liner), which occurs during penetration of the core barrel. $\mathrm{P}=$ pervasive contamination, $\mathrm{S}=$ superficial contamination (caused by smearing), and $\mathrm{U}=$ uncontaminated.

Figure $24 \mathrm{~b}$ shows the spectrum of variance in the WCMS record of Site 711 for the pre-Brunhes, middle and lower Pleistocene interval. As noted above, the dominant spectral components in this record differ markedly from those of the WCMS record of the Brunhes Chron at this site. In particular, the strong $\sim 100-\mathrm{k} . \mathrm{y}$. (eccentricity) period identified in the WCMS spectrum for the Brunhes interval (Fig. 24A) is absent from the pre-Brunhes spectrum (Fig. 24B), although the 413- and 54-k.y. eccentricity periods (Imbrie, 1985) may be represented in this spectrum by the peaks at 400 and 55 k.y. Also, further spectral peaks at around the obliquity ( $41 \mathrm{k} . \mathrm{y}$.) and precessional periods ( 23 and 19 k.y.) suggest that orbital forcing in the Milankovitch band still modulates carbonate accumulation (reflected by WCMS variations) in the early, pre-Brunhes Pleistocene interval at this site. Once again, however, several significant peaks in variance density occur at periods that do not correspond to the primary Milankovitch cycles, most notably at 78 k.y. Although minor discrepancies in the spectral positions at which the primary Milankovitch responses occur (e.g., 40 k.y. instead of 41 k.y., and $21.1 \mathrm{k} . \mathrm{y}$. instead of $23 \mathrm{k} . \mathrm{y}$.) may possibly be explained by small errors in the age model for the WCMS time series, the existence of a major peak in variance density at around $78 \mathrm{k} . \mathrm{y}$. is more difficult to account for. However, a change in the dominant 


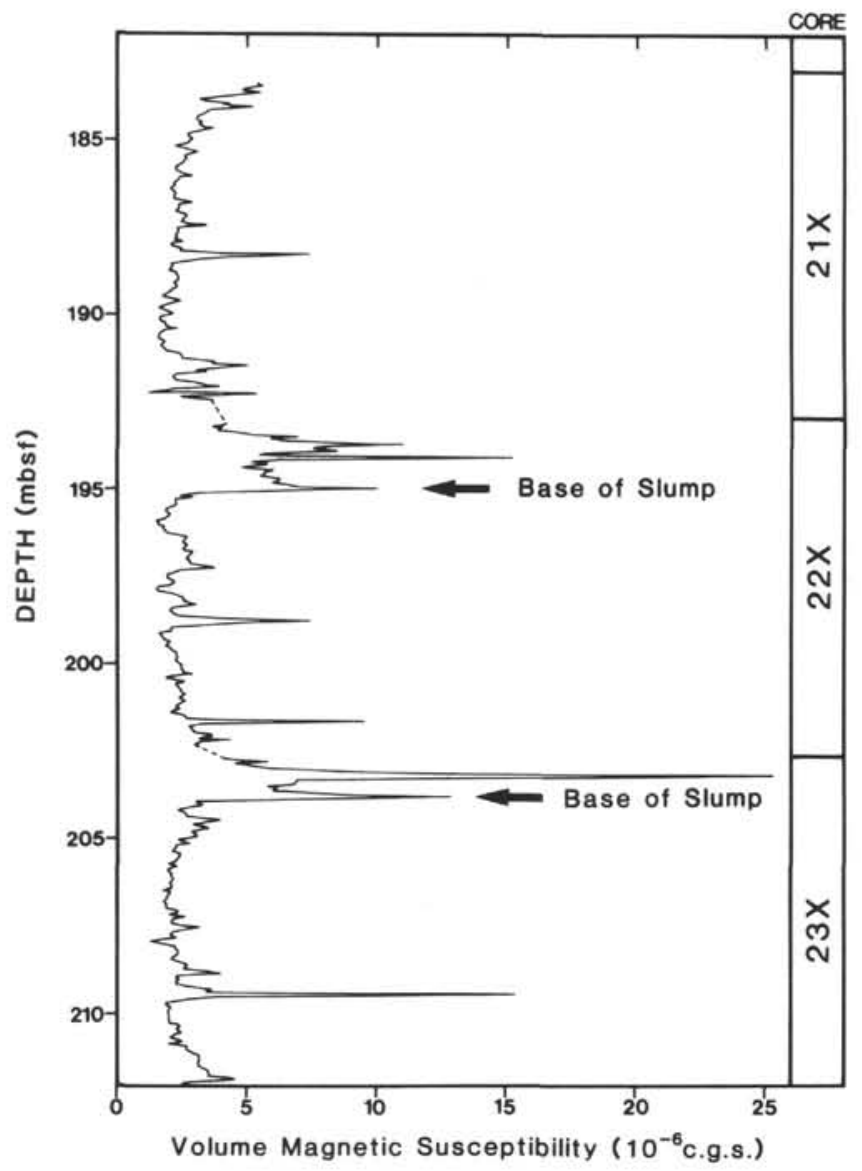

Figure 21. WCMS profile of a subsection from Hole 707A, between 183 and $220 \mathrm{mbsf}$, showing the characteristic "graded" (density stratified) motif associated with contamination by metallic drilling artifacts in rotary-drilled XCB cores. The arrows indicate the bases of spurious graded beds, that is, horizons consisting of sediment washed in from uphole, containing ferrous metal contaminants that settle out of suspension toward the base of the slumped interval.

spectral components of Quaternary oxygen isotope time seriesfrom 41 k.y. (obliquity cycle) during the Matuyama Chron, to 100 k.y. (eccentricity cycle) during the Brunhes-has been well documented (e.g., Pisias and Moore, 1981; Ruddiman et al., 1986; Ruddiman and Raymo, 1988). This transition is clearly apparent in the spectra of WCMS (proxy-carbonate) variations at Site 711.

Possible mechanisms that may be invoked to explain how climatic and/or orbital variations control carbonate dissolution in the tropical Indian Ocean are discussed below (see "Orbital Forcing of WCMS Variations” section, this chapter).

\section{DISCUSSION AND CONCLUSIONS}

The following discussion does not aim to encompass all aspects of the various applications for WCMS data described above, since, in many instances, the foregoing examples were entirely illustrative and require no further explanation or discussion. Instead, selected themes are developed, where necessary, to offer explanations or suggest possible mechanisms to account for the observations described above, or to make recommendations for the future use of WCMS measurements on ODP (or similar) cruises.

\section{Lithostratigraphic Applications}

As a tool for routine logging of whole-core sections when they arrive on deck, WCMS is analogous to whole-core geophysical logging tools like the GRAPE or $P$-wave logger, and to downhole, wireline logging systems like spontaneous potential, resistivity, sonic, gamma ray or gamma spectroscopy, and so forth. As a lithologic indicator, WCMS is most directly analogous to gamma ray, spectral gamma ray, or gamma spectroscopy wireline logging tools. Accordingly, on future ODP legs, it may be useful for lithostratigraphic purposes, to routinely integrate the results of WCMS measurements with data from the GRAPE and $P$-wave logger (e.g., Ciesielski, Kristoffersen, et al., 1988, p. 190). Whole-core physical properties data may be combined with WCMS, either in the form cross-plots, or, in the case of bulk-density estimates derived from acoustic velocity measurements, used to apply a correction factor to volume-MS values. These corrected data may then be expressed in the form of "magnetic accumulation rate (MAR)" indexes (e.g., Bloemendal, 1983), where adequate age controls are available. Bulk MAR curves, based on corrected WCMS data, often closely parallel variations in lithogenic mass accumulation rate (e.g., Clemens and Prell, in press), which may reflect carbonate dissolution effects at sites where lithogenic fluxes are constant over time, or monitor variations in the flux density of terrigenous components (e.g., Bloemendal et al., 1988).

Using the now fully automated WCMS logging system on board JOIDES Resolution, in conjunction with a simple XYgraph plotting program, it is possible to generate plots (or printouts) of WCMS as a function of depth on a core-by-core, or even section-by-section, basis for immediate inspection by shipboard sedimentologists and stratigraphers before the cores are split open for lithologic description and sampling. The potential value of plotting WCMS profiles on a core-by-core basis may be illustrated with reference to Figure 2, which shows a WCMS profile of Core 115-711A-1H plotted alongside the lithologic log and carbonate content record of this core. The WCMS profile shown in Figure 2 is based on measurements made by manually passing whole-core sections, $3 \mathrm{~cm}$ at a time, through a WCMS loop-type sensor, which required approximately $40 \mathrm{~min}$ to complete (including the time taken to exchange and prepare individual core sections for analysis). This period of time may be compared directly with the $40+$ man-hours required to measure (gasometrically) the carbonate content of samples taken at $5-\mathrm{cm}$ intervals from this core, upon which its carbonate content profile (Fig. 2, left) is based.

The above comparison emphasizes the great speed and simplicity with which WCMS logging can provide valuable lithologic information even before cores are split open for description and sampling. This attribute is particularly important in geochemical studies, in which whole-core sections often have to remain intact and sealed to prevent oxidation of the sediment on its exposure to the atmosphere. It should also be remembered that, unlike most methods of carbonate content determination, WCMS measurements are totally nondestructive and do not disturb the physical, chemical, mineralogical, or magnetic properties of the sediment in any way.

The combined attributes of speed, simplicity, and nondestructiveness make WCMS logging an ideal tool for high-resolution correlation between offset cores recovered from adjacent holes at ODP sites. It is essential that interhole correlation is effected with the highest possible stratigraphic resolution if composite sequences from individual ODP sites are to be used, for example, in studies of Milankovitch-band cyclicity in paleoceanographic records, based on spectral analysis of downcore data. The use of Shaw Diagrams, constructed by correlating the 


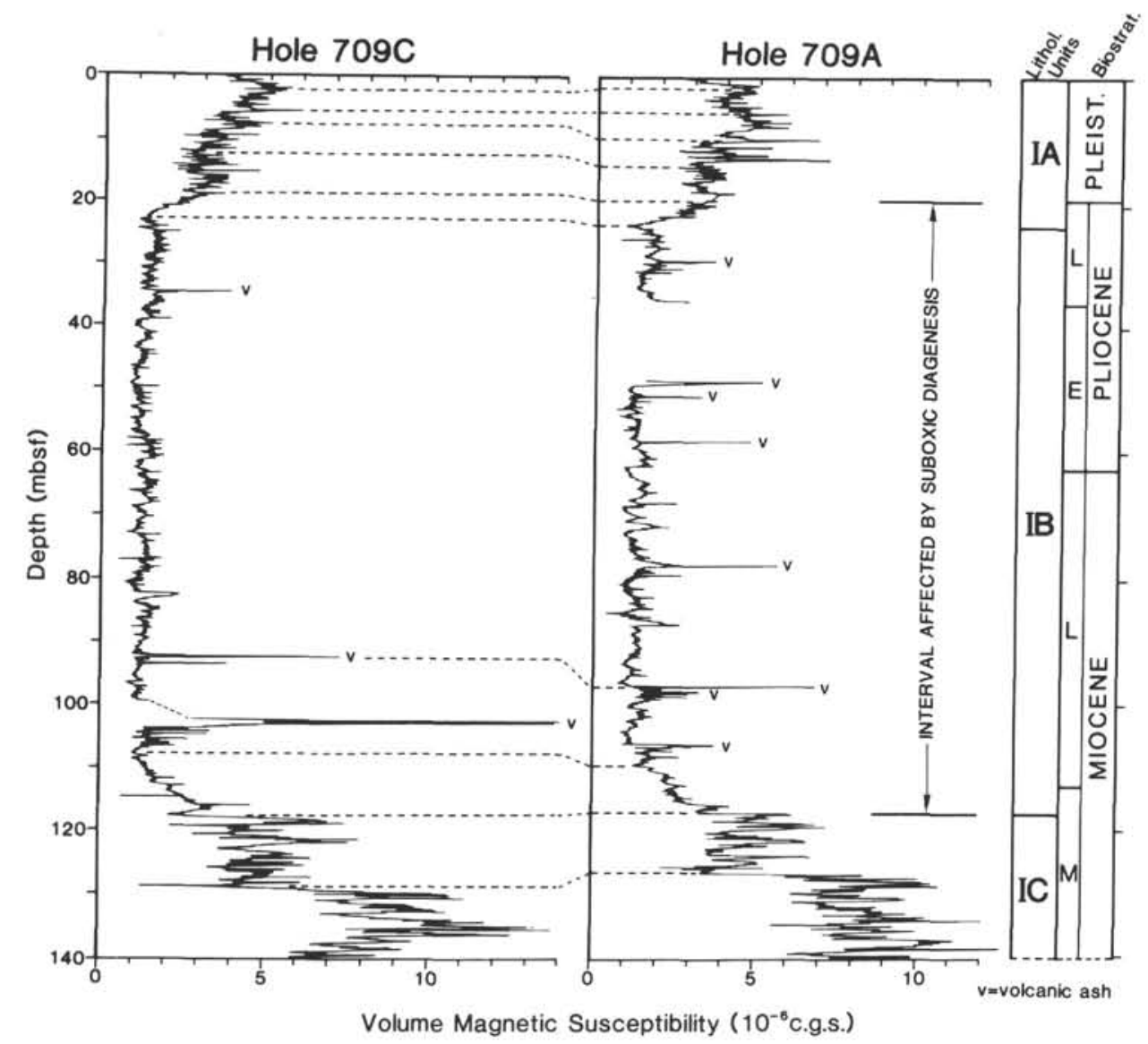

Figure 22. WCMS profiles of Holes 709A and 709C, to 140 mbsf, showing the relationship between lithologic units and WCMS variations for the interval affected by early (suboxic) diagenesis at this site (lithologic Subunit IB).

WCMS profiles of subsidiary holes at ODP sites (e.g., Figs. 9, 11,13 , and 18), provides an effective tool for reconstructing composite sequences by identifying stratigraphic discontinuities, both real or the result of coring irregularities. Shaw Plots are also useful for extrapolating magneto- or biostratigraphic datums recognized in one hole to the sequences recovered from adjacent holes at the same or nearby sites. For example, the Shaw Diagram for Site 710 , shown in Figure 18, above, may be used to extrapolate the nine Quaternary nannofossil datums identified by Okada (this volume) from Hole $710 \mathrm{~B}$, in which a major repeated sequence occurs (corresponding to the entire length of Core $115-710 \mathrm{~B}-3 \mathrm{H})$, to the relatively uninterrupted sequence recovered from Hole $710 \mathrm{~A}$.

\section{Coring Irregularities}

Possible mechanisms that may explain how successive coring runs may recover the same sequence, thus resulting in the situation that occurred at the top of Hole 710B, are discussed in detail by Ruddiman et al. (1987). In essence, unlike repenetration during a single coring run-generally caused by inadequate heave compensation during the passage of an abnormally large wave (i.e., vertical displacement of the ship), the recoring of the same sequence by successive cores is probably caused by the ship suddenly drifting off station between coring runs (i.e., lateral displacement), usually during severe weather and/or sea conditions. This causes the entire drill string and bottom-hole assembly to be lifted above the base of the hole without drilling platform instruments recording any change in the length of string advanced. As the drill bit is then "washed down" in read- iness to core the next interval in the sequence, it actually descends only to a point approximately equivalent to the top of the previously cored interval. If side-wall coring then occurs, the next interval of the sequence recovered will essentially repeat the stratigraphic record captured by the previous core. Naturally, if the ship subsequently returns, equally abruptly, to its original position above the acoustic beacon, then the drill bit may be "washed down" further than intended (or recorded) between coring runs, thus resulting in an "unrecorded interval of no recovery" between successive cores.

With regard to the use of WCMS logging to identify contamination of APC and XCB cores by metallic artifacts, as exemplified by the cores recovered from Hole $707 \mathrm{~A}$, it should be noted that the extent of contamination at this site was probably abnormal relative to most pelagic sites, as a result of a combination of the following adverse drilling conditions.

1. The sediments recovered from Hole $707 \mathrm{~A}$, between 0 and 151 mbsf, consisted mainly of unconsolidated and only weakly cohesive, foraminifer oozes. Such sediments are likely to be much more prone to liquefaction during penetration of the core barrel, and to slumping upon removal of intervals of core, than are more cohesive sediments containing a higher proportion of nannofossil or lithogenic clay.

2. Loose, sandy, foraminifer-rich sediment is also an effective abrasive agent, capable of scouring rust particles from the surface of the drill string.

3. Even more effective in this context, however, were a series of chert stringers encountered at several points in the sequence 


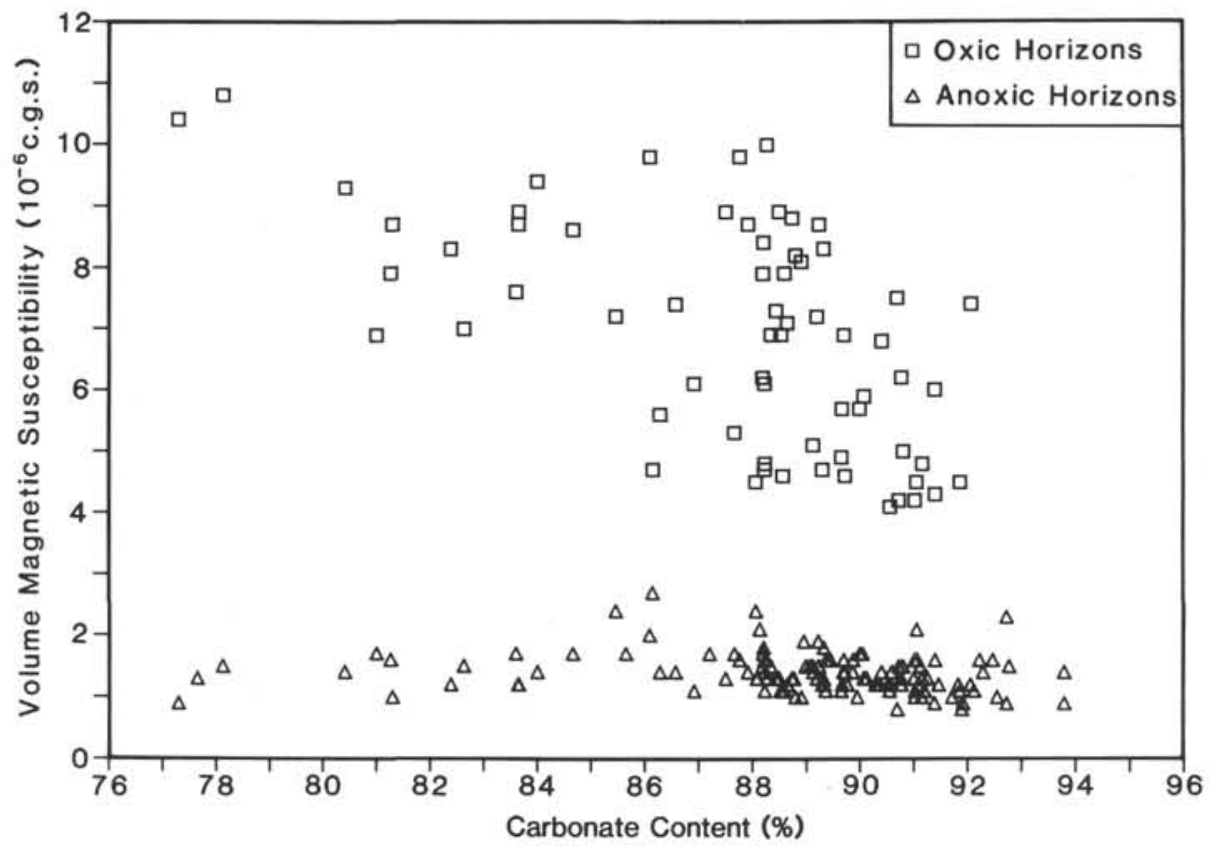

Figure 23. Relationship between carbonate content (shipboard "Geochemistry" data) and WCMS for the interval of Hole 709A shown in Figure 22 (0-140 mbsf), illustrating the concept of "anomalously low" WCMS values (relative to carbonate content) of sediments affected by suboxic diagenesis. Data from oxic horizons of Hole 709A (lithologic Subunits IA and IC) are plotted as squares, whereas data from anoxic horizons (lithologic Subunit IB) are plotted as triangles.

of Hole 707A, which not only stripped the drill string of paint and rust in places, but also lacerated the surface of the underlying steel pipe.

4. The drill pipe in use aboard the JOIDES Resolution during Leg 115 was previously rust-proofed about 2 yr earlier (first used, after rustproofing, on Leg 103), and the outer surface of many sections of pipe had become visibly rusted.

Clearly, therefore, if drilling contamination of the kind experienced at Site 707 (and other Leg 115 sites) is to be avoided on future ODP legs, regular inspections to determine the condition of the drill pipe should be conducted at intervals of less than 2 yr. It is also essential that the rustproofing process (effectively zinc plating) is applied both to the interior and exterior of the drill pipe.

\section{Early Diagenesis in Leg 115 Sequences}

The interval of "reduced" (anoxic/suboxic) sediment encountered between the late Miocene and early Pleistocene horizons of several Leg 115 holes-including those of the "Carbonate Dissolution Profile" (CDP), was clearly distinguished from the sediments lying above and below it in these sequences, not only by ephemeral characteristics such as its grayish green colors, but also by a more permanent and quantifiable WCMS signature deriving from the effect that redoxomorphic diagenesis has on magnetic iron oxides or oxyhydroxides in deep-sea sediments. The WCMS profiles of CDP holes (Fig. 15) appeared to suggest that the intensity of reduction-presumably related to the amount of organic matter originally present in the sediment-varied according to the water depth of the site: shallower sites being more severely affected than deeper sites. With regard to the possible causes of this interval of reduced sediment, it is notable that a similar, though generally more intensely reduced (and organic rich) interval, of broadly equivalent age (late Miocene through early Pleistocene), was encountered in all of the holes drilled on the Oman continental margin (Sites 723 through 730) and Owen Ridge (Sites 721, 722, and 731), in the northwest Indian Ocean, during Leg 117 (Prell, Niitsuma, et al., 1989).

In Leg 117 holes, the interval of anoxic sediment was clearly associated with an abundance of well-preserved planktonic foraminifer and nannofossil assemblages; a large increase in bulk sediment accumulation rate; and a higher proportion of organic carbon and biogenic silica in the sediment. These attributes were interpreted as indicating that the anoxic interval in Leg 117 holes was related to increased organic productivity and thus an expansion and intensification of the oceanic oxygen-minimum layer (OML). The increase in organic productivity was thought to be related to the establishment of monsoon-driven upwelling in the northwest Indian Ocean, which, according to general atmospheric circulation models (e.g., Hahn and Manabe, 1975), may be linked to the uplift of the Tibetan Plateau. As monsoondriven upwelling commenced, sites lying close to, or within, the OML experienced significant increases in bulk-sediment and organic-carbon accumulation rates, and also in the state of preservation of organic detritus. Consequently, postdepositional remineralization of this organic matter proceeded by means of suboxic diagenesis (see "Identification of Early Diagenesis" section, this chapter).

In the light of these preliminary findings from Leg 117 in the northwest Indian Ocean, it seems possible that the interval of reduced sediment identified in holes drilled in the equatorial Indian Ocean during Leg 115 may also be the result of an expansion in the OML, at least in part related to the establishment of monsoon-driven upwelling in the Arabian Sea and Somali Basin in late Miocene times. This possibility would be consistent with the observations noted above, that the reduced interval in Leg 
A

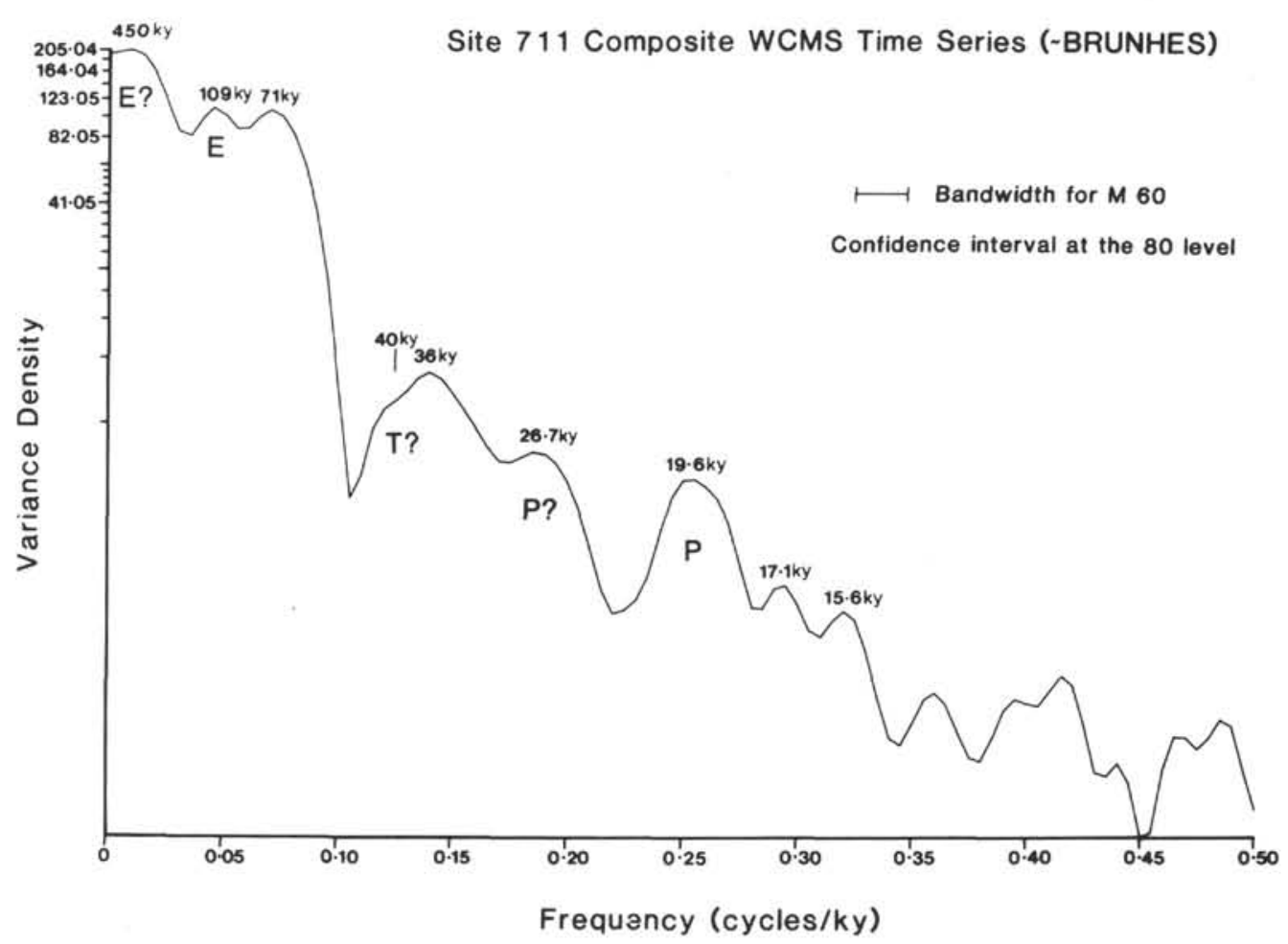

B

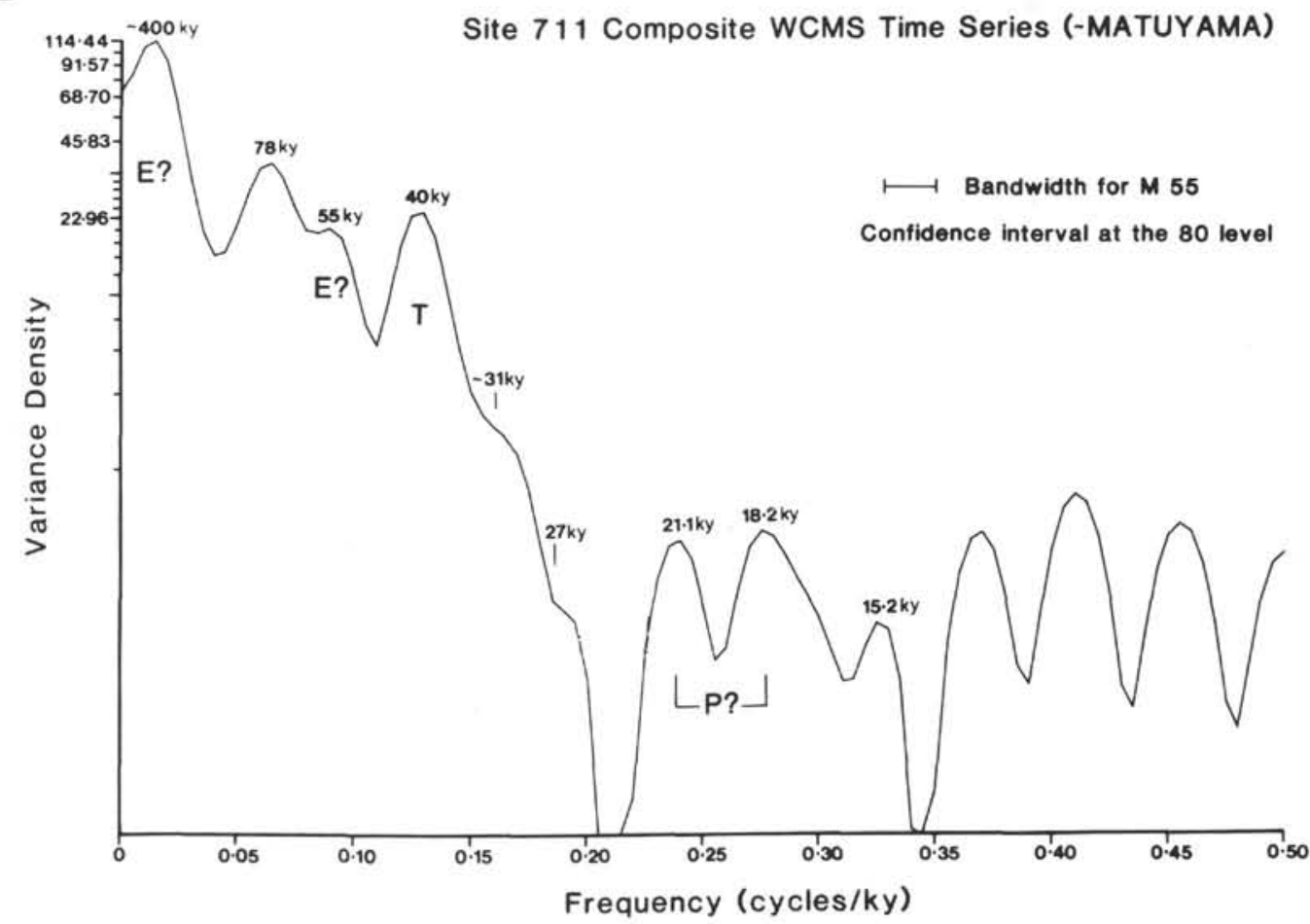

Figure 24. Logarithmic variance-density spectra of an interpolated WCMS time series from the Pleistocene interval of Site 711, based on the composite WCMS profile for this site shown in Figure 12. A. WCMS variance spectrum for the middle and late Pleistocene interval at Site 711, that is, between 0.92 and $0.015 \mathrm{Ma}(0.15-7.5 \mathrm{mbsf})$. B. WCMS variance spectrum for the middle and lower Pleistocene interval at Site 711, that is, between 0.82 and $1.87 \mathrm{Ma}(6.5-12.6$ mbsf). 
115 CDP holes is more clearly developed at the shallower sites, and appears to be associated with an overall increase in bulk sediment accumulation rates, and in many instances, an increase in biogenic silica content of the sediment.

An additional, and possibly even more significant factor that may also have influenced organic productivity, and thus the thickness and intensity of the OML in the equatorial Indian Ocean, was the establishment of the modern equatorial water mass and related circulation patterns, which followed the northward drift across the equator of the southern tip of the Indian subcontinent, in the late Miocene (Vincent, 1974, 1977). Naturally, in plate tectonic terms, this event was also related to Himalayan uplift, and thus to the establishment of monsoon-driven upwelling in the Arabian Sea and Somali Basin. The return to conditions suitable for oxic sediment accumulation in the late Pliocene, at Leg 115 as well as Leg 117 sites, was probably caused by paleoceanographic changes related to the onset of Northern Hemisphere glaciations. Here again it has been suggested (e.g., see Ruddiman and Raymo, 1988, and references therein) that a key element in the triggering of these glaciations was the rapid acceleration in the rates of uplift of the Tibetan Plateau (and North America) at this time.

\section{Orbital Forcing of WCMS Variations}

Two examples were described above of the paleoclimatic control, or at least orbital forcing, of WCMS of deep-sea sediments from the North Atlantic (Fig. 6) and equatorial Indian Oceans (Figs. 3 and 12). These examples demonstrated the application of WCMS as a proxy paleoclimatic indicator for Quaternary deep-sea sediments, which consist of climatically modulated oscillations in carbonate content related to dilution, dissolution, or productivity variations (e.g., Volat et al., 1980). These examples also emphasize the potential value of WCMS logging as a lithologically related reconnaissance tool in studies that search for Milankovitch-type cyclicity in the geologic record beyond that of the Pliocene-Pleistocene epochs (e.g., Weedon, 1989). In this context, the high-amplitude, high-frequency oscillations in WCMS (proxy carbonate) within the condensed, early and middle Miocene sequences of several Leg 115 CDP holes (e.g., Fig. 4) suggests the possibility of orbital influences on carbonate accumulation rates in the tropical Indian Ocean during certain intervals before the onset of Northern Hemisphere glaciations in the late Pliocene.

Peterson and Prell (1985b) discussed, in detail, various mechanisms that have been put forward to explain how paleoclimatic, and/or orbital variations control carbonate accumulation in the tropical Indian Ocean. These included: (1) global (i.e., continent-ocean exchange) organic-carbon inventory models (e.g., Shackleton, 1977); (2) shelf-basin exchange, organic-carbon inventory models (e.g., Broecker, 1981, 1982); (3) shelf-basin exchange, carbonate-carbon inventory models (e.g., Berger and Winterer, 1974; Hay and Southam, 1977); and (4) oceanic deepwater circulation models (e.g., Streeter and Shackleton, 1979; Volat et al., 1980; Curry and Lohmann, 1982). Of these, Peterson and Prell favored a deep-water circulation model to account for the orbitally forced cycles of carbonate dissolution that they identified in their eastern equatorial Indian Ocean cores. These cycles appeared to lag systematically behind oxygen-isotope variations in the same cores, but exhibited dominant 100-k.y. (eccentricity) and 41-k.y. (obliquity) spectral periods that were highly coherent with equivalent peaks in the spectrum of oxygen-isotope variance. Unlike Site 711 , however, a well-defined precessional component at $23 \mathrm{k}$.y. was absent from the spectra of carbonate dissolution cycles in the cores examined by Peterson and Prell (though a clear 19-k.y. peak was present), leading these authors to favor a deep-water circulation model to explain the cycles, since a strict interpretation of carbon inventory models requires that dissolution cycles should be coherent with all the dominant periods in the Milankovitch band.

In addition to the above models considered by Peterson and Prell, carbonate accumulation rates further west in the equatorial Indian Ocean (e.g., Site 711) may possibly be influenced by orbitally forced variations in monsoon-driven upwelling in the Somali Basin and western Arabian Sea (e.g., Prell, 1984). Such variations may possibly affect the circulation patterns and rates of carbonate productivity in surface waters of adjacent areas, as discussed above.

\section{SUMMARY}

The low-field ( $<1 \mathrm{Oe})$, volume magnetic susceptibility ( $K$ or MS) of a substance is a constant of proportionality that relates the intensity of magnetization (M) induced in the substance, by an applied magnetic field $(\mathrm{H})$, to the strength of that field, that is, $K=\mathrm{M} / \mathrm{H}$. Magnetic susceptibility, therefore is totally independent of the Earth's magnetic field and is, in effect, simply a measure of the amount of magnetizable material the substance contains.

Most of the magnetizable constituents in deep-sea sediments reside in the lithogenic fraction of the sediment (an important exception is bacterial magnetite, if present), and not only include magnetic iron oxides (e.g., hematite, magnetite, etc.), but also all compounds containing $\mathrm{Fe}^{2+}, \mathrm{Fe}^{3+}$, and $\mathrm{Mn}^{2+}$ ions. These so-called paramagnetic substances include clay minerals, rock-forming ferromagnesian silicate minerals, and authigenic ferromanganese oxyhydroxide mineraloids (e.g., limonite, todorokite) often present in the pore waters of deep-sea sediments or as nodules, micronodules, and so on. Biogenic carbonate and silica, in contrast, are diamagnetic, which means they exhibit weak, negative MS values. Accordingly, downcore variations in the MS of deep-sea sediments often reflect changes in their lithologic composition, that is, fluctuations in the ratio of biogenic to lithogenic components in the sediment (often the same as \%-carbonate).

Whole-core (WC) measurements of volume MS, therefore, offer an extremely simple, rapid, and nondestructive technique for quantitatively logging lithologic variations of deep-sea sediment cores immediately after they arrive on deck, prior to them being split open for lithologic description and sampling. WCMS logging also provides a tool for ultra-high-resolution lithostratigraphic correlation between subsidiary holes drilled at ODP sites. This is particularly useful when composite, stratigraphically continuous sequences for individual ODP sites are to be reconstructed by dovetailing the uninterrupted records obtained from the middle sections of offset cores recovered from subsidiary holes. An obvious corollary to this application is the use of WCMS logging to identify stratigraphic discontinuities and repeated sequences resulting from coring irregularities that are generally caused by abrupt, vertical, or lateral displacements of the drilling vessel during severe weather or sea conditions.

Another form of disturbance that often affects rotary drilled and hydraulic piston cores is contamination by metallic artifacts such as fragments of pipe rust or particles of abraded drill bit, and so on. Naturally, ferrous metal contaminants are strongly magnetic and may easily be identified, therefore, by WCMS logging, as such particles exhibit much higher WCMS values than most pelagic lithologies (with the exception of volcanic-ash-rich sediments). Pipe-rust contamination of APC cores from Hole 707A was characterized by a highly distinctive "sawtooth" motif in the WCMS profile of this hole. Major peaks, or clusters of related peaks, in the WCMS profile of Hole 707A corresponded exactly with the top of individual cored intervals of the sequence, with WCMS values beneath these initial peaks tapering off downhole. The WCMS peak(s) at the top of each core corresponded to highly disturbed sediment pervasively contaminated 
by metallic artifacts, whereas the gradual decline in WCMS values beneath this initial peak was related to the smearing of contaminated material from the top of the core, around the exterior of the sediment column, during penetration of the core barrel.

In addition to between-hole correlations, WCMS profiles can be used to correlate between holes at different sites (i.e., between sites) when changes in the lithologic composition of the sediments involved are controlled by regional, or even larger scale variations in oceanographic variables (e.g., CCD, sealevel, upwelling, productivity, bottom currents, etc.), or detrital sediment source and flux density. Similarly, the high proportion of primary titanomagnetite normally present in unaltered, basic volcanic ash, or secondary pyrite (after titanomagnetite) in degraded volcanic ash, provides the basis for WCMS to be used as a correlation tool in studies of tephrostratigraphy ("tephrochronology"). An example of this application is provided by Site 706 (0-30 mbsf), where 127 points of correlation between subsidiary holes were identified by cross-matching the WCMS profiles of each hole. Virtually all of the peaks in the WCMS profiles of these holes corresponded to volcanic-ash horizons in varying stages of alteration.

Lithologic variations of deep-sea sediments are frequently modulated by climatic fluctuations and/or orbital forcing (e.g., Dean and Gardner, 1986). It is well established, for example, that oscillations in the carbonate content of Quaternary deepsea sediments globally, are related to northern hemisphere glacial-interglacial cycles, by means of the mechanisms of carbonate dissolution, dilution, and/or productivity variations (Volat et al., 1980). For sediments such as these, WCMS logging not only provides a means of long-distance, interregional scale correlation, but may also be used as a proxy paleoclimatic indicator, duly assisting the task of climatostratigraphic zonation by more costly, time consuming, and laborious microfossil and isotopic paleoclimatic indexes. In the present study, this application is exemplified by reference to the WCMS profiles of (1) a suite of eight deep-sea cores from the North Atlantic (cf. DSDP Site 608 ), in which carbonate and WCMS cycles were climatically controlled by means of the combined mechanisms of productivity variations and dilution by terrigenous (mainly icerafted) sediment; and (2) Site 711, where Quaternary \%-carbonate and WCMS cycles are controlled by dissolution and exhibit spectral periods corresponding to all of the primary Milankovitch responses, but also contain anomalous spectral components with periods of $\sim 71 \mathrm{k} . \mathrm{y}$. in the Brunhes Chron and $\sim 78 \mathrm{k} . \mathrm{y}$. in the Matuyama Chron.

Stratigraphic intervals of deep-sea sediments that have been affected by early (suboxic) diagenesis because of high initial concentrations of organic matter in the sediment are often associated with changes in sediment color (white to gray, or brown to green), and a characteristic degradation in WCMS values within that interval. Both of these changes are related to the instability of ferric $\left(\mathrm{Fe}^{3+}\right)$ ions in oxides, oxyhydroxides, and clay minerals under reducing conditions. Hence, suboxic organic matter diagenesis leads to the "dissolution" (bacterially mediated reduction or ionic dissociation) of detrital magnetic iron oxides and oxyhydroxides in the sediment, which therefore degrades its WCMS signal-often in proportion to the duration and intensity (related to initial $\mathrm{C}_{\mathrm{org}}$ content) of the diagenesis.

An interval of greenish-gray-colored, reduced sediment of late Miocene to late Pliocene or early Pleistocene age was identified in a number of holes drilled during Leg 115. The WCMS profiles of these holes indicated that within the interval of greenish gray sediment, suboxic diagenesis had depleted the iron oxide/oxyhydroxide minerals originally present, thus degrading the WCMS signal in this interval relative to that of "normally" oxidized sediments in the same sequence. The interval of reduced sediment was also associated with increased bulk sedi- ment accumulation rates and a higher proportion of biogenic silica in the sediment. A similar, though more intensely reduced, interval was also identified in holes drilled in the northwest Indian Ocean during Leg 117. In Leg 117 holes, the interval of reduced sediment was thought to be related to the development of monsoon-driven upwelling in the Arabian Sea at the beginning of the late Miocene, which considerably increased organic productivity and led to an expansion and intensification of the oceanic OML (Prell, Niitsuma, et al., 1989). An additional, possibly more significant factor influencing sediment accumulation rates, organic productivity, and OML thickness at Leg 115 sites was the establishment of the modern equatorial water mass and circulation systems in the tropical Indian Ocean, as the southern tip of the Indian subcontinent drifted north of the equator at the beginning of late Miocene times (Vincent, 1974, 1977).

\section{ACKNOWLEDGMENTS}

I am extremely grateful to several fellow members of the scientific drilling party of Leg 115 for occasionally relieving me of my responsibility for WCMS measurements to allow me a few hours of much-needed sleep. These members were (in alphabetical order): J. Backman, R. Duncan, M. Fisk, J. Greenough, R. Hargraves, A. MacDonald, J. Tauxe, and J. Weisbruch. I apologize if I have omitted the name of any other Leg 115 participant who may also have helped me in this or any other way, without my knowledge. A special note of thanks to J. Tauxe for his invaluable assistance in many ways beyond the call of duty, but specifically for help with WCMS data processing, and for developing software specifically to meet my needs. I am also very grateful to N. J. Shackleton for his oxygen-isotope measurements of Core 115-711A-1H and, along with J. Backman, for giving me the opportunity to participate in Leg 115 . I thank the U.K. Natural Environment Research Council for financial support (Grant Ref. GST/02/260).

\section{REFERENCES}

Amin, B. S., Likhite, S. D., Radhakrishnamurty, C., and Somayajulu, B.L.K., 1972. Susceptibility stratigraphy and palaeomagnetism of some deep Pacific Ocean cores. Deep-Sea Res., 19:249-252.

Arthur, M. A., Dean, W. E. and Stow, D.A.V., 1984. Models for the deposition of Mesozoic-Cenozoic fine-grained, organic-carbon-rich sediment in the deep-sea. In Stow, D.A.V., and Piper, D.J.W (Eds.), Fine-Grained Sediments: Deep-Water Processes and Facies. Spec. Publ., Geol. Soc. London, 15:527-560.

Backman, J., Duncan, R. A., et al., 1988. Proc. ODP, Init. Repts., 115: College Station, TX (Ocean Drilling Program).

Bascomb, C. L., 1974. Physical and chemical analyses of $<2 \mathrm{~mm}$ samples. In Avery, B. W., and Bascomb, C. L. (Eds.), Soil Survey Laboratory Methods. Soil Survey Tech. Monogr., 6:14-41.

Bender, M. L., and Heggie, D. T., 1984. Fate of organic carbon reaching the deep-sea floor: a status report. Geochim. Cosmochim. Acta, 48:977-986.

Berger, W. H., 1973. Deep-sea carbonates: Pleistocene dissolution cycles. J. Foraminiferal Res., 3:187-195.

Berger, W. H., and Winterer, E. L., 1974. Plate stratigraphy and the fluctuating carbonate line. In Hsü, K. J., and Jenkyns, H. (Eds.), Pelagic Sediments on Land and Under the Sea. Spec. Publ., Int. Assoc. Sediment., 1:11-48.

Berner, R. A., 1981. A new geochemical classification of sedimentary environments. J. Sediment. Petrol., 51:359-365.

Bloemendal, J., 1982. The quantification of rates of total sediment influx to Llyn Goddionduon, Gwynedd [Ph.D. thesis]. Univ. Liverpool, United Kingdom.

1983. Paleoenvironmental implications of the magnetic characteristics of sediments from Deep-Sea Drilling Project Site 514, Southeast Argentine Basin. In Ludwig, W. J., Krasheninnikov, V. A., et al., Init. Repts. DSDP, 71, Pt. 2: Washington (U.S. Govt. Printing Office), 1097-1108.

Bloemendal, J., Lamb, B., and King, J., 1988. Paleoenvironmental implications of rock-magnetic properties of late Quaternary sediment 
cores from the eastern equatorial Atlantic. Paleoceanography, 3:6187.

Bloemendal, J., Oldfield, F., and Thompson, R., 1979. Magnetic measurements used to assess sediment influx at Llyn Goddionduon. $\mathrm{Na}$ ture, 280:50-53.

Boillot, G., Winterer, E. L., Meyer, A. W., et al., 1987. Proc. ODP, Init. Repts., 103: College Station, TX (Ocean Drilling Program).

Broecker, W. S., 1971. Calcite accumulation rates and glacial to interglacial changes in oceanic mixing. In Turekian, K. K. (Ed.), The Late Cenozoic Glacial Ages: New Haven, CT (Yale Univ. Press), 239-265. , 1981. Glacial to interglacial changes in ocean and atmosphere chemistry. In Berger, A. (Ed.), Climatic Variations and Variability: Facts and Theories: Hingham, MA (D. Reidel), 109-120. 1982. Glacial to interglacial changes in ocean chemistry. Prog. Oceanogr., 11:151-197.

Burns, R. G., and Burns, V. M., 1981. Authigenic oxides. In Emiliani, C. (Ed.), The Sea (Vol. 7): The Oceanic Lithosphere: New York (Wiley-Interscience), 875-914.

Canfield, D. E., and Berner, R. A., 1987. Dissolution and pyritization of magnetite in anoxic marine sediments. Geochim. Cosmochim. Acta, 51:645-659.

Chang, S-B. B., and Kirschvink, J. L., 1987. Biogenic magnetite as a primary remanence carrier in limestone deposits. Phys. Earth Planet. Inter., 46:289-303.

Chuey, J. M., Rea, D. K., and Pisias, N. G., 1987. Late Pleistocene paleoclimatology of the central equatorial Pacific: a quantitative record of eolian and carbonate deposition. Quat. Res., 28:323-339.

Ciesielski, P. F., Kristoffersen, Y., et al., 1988. Proc. ODP, Init. Repts., 114: College Station TX (Ocean Drilling Program).

Clemens, S. C., and Prell, W. L., in press. One million year record of summer-monsoon winds and continental aridity from the Owen Ridge (Site 722), northwest Arabian Sea. In Prell, W. L., Niitsuma, N., Proc. ODP, Sci. Results, 117: College Station, Texas (Ocean Drilling Program).

Collinson, D. W., 1983. Methods in Rock Magnetism and Palaeomagnetism: Techniques and Instrumentation: London (Chapman and Hall).

Crowley, T. J., 1985. Late Quaternary carbonate changes in the North Atlantic, and Atlantic-Pacific comparisons. In Sundquist, E. T., and Broecker, W. S. (Eds.), The Carbon Cycle and Atmospheric $\mathrm{CO}_{2}$ : Natural Variations Archean to Present. Am. Geophys. Union Monogr., 32:271-284.

Curry, W. B., and Lohmann, G. P., 1982. Carbon isotopic changes in benthic foraminifera from the western South Atlantic: reconstruction of glacial abyssal circulation patterns. Quat. Res., 18:218-235.

Curtis, C. D., 1983. Microorganisms and diagenesis of sediments. In Krumbein, W. E. (Ed.), Microbial Geochemistry: Oxford (Blackwell Scientific Publ.), 263-286.

Dean, W. E., and Gardner, J. V., 1986. Milankovitch cycles in Neogene deep-sea sediments. Paleoceanography, 1:539-553.

Dearing, J. D., 1983. Changing patterns of sediment accumulation in a small lake in Scandia, southern Sweden. Hydrobiologia, 103:59-64.

Dearing, J. D., Elner, J. K., and Happey-Wood, C. M., 1981. Recent sediment influx and erosional processes in a Welsh upland lake catchment, based on magnetic susceptibility measurements. Quat. Res., $16: 356-372$.

Dreimanis, A., 1962. Quantitative gasometric determination of calcite and dolomite by using the Chittick Apparatus. J. Sediment. Petrol., 32:520-529.

Freeman, R., 1986. Magnetic mineralogy of pelagic limestones. Geophys. J. R. Astron. Soc., 85:433-452.

Froelich, P. N., Klinkhammer, G. P., Bender, M. L., Luedtke, N. A., Heath, G. R., Cullen, D., Dauphin, P., Hartman, B., Hammond, D., and Maynard, V., 1979. Early oxidation of organic matter in pelagic sediments of the eastern equatorial Atlantic: suboxic diagenesis. Geochim. Cosmochim. Acta, 43:1075-1090.

Gardner, J. V., Nelson, C. S., and Baker, P., 1986. Distribution and character of pale green laminae in sediment from the Lord Howe Rise: a probable Late Neogene and Quaternary tephrostratigraphic record. In Kennett, J. P., von der Borch, C. C., et al., Init. Repts. DSDP, 90: Washington (U.S. Govt. Printing Office), 1145-1160.

Ghil, M., 1987. Nonlinear phenomena in climate dynamics. In Nicolis, C., and Nicolis, G. (Eds.), Irreversible Phenomena and Dynamical Systems Analysis in Geosciences. NATO ASI, Ser. C, 194:313-320.
Hahn, D. G., and Manabe, S., 1975. The role of mountains in the south Asian monsoon circulation. J. Atmos. Sci., 32:1515-1541.

Hay, W. W., and Southam, J. R., 1977. Modulation of marine sedimentation by the continental shelves. In Andersen, N. R., and Malahoff, A., The Fate of Fossil Fuel $\mathrm{CO}_{2}$ in the Oceans: New York (Plenum Press), 569-604.

Hays, J. D., Lozano, J. A., Shackleton, N. J., and Irving, G., 1976. Reconstruction of the Atlantic and western Indian Ocean sectors of the 18,000 yr. B.P. Antarctic Ocean. Mem. Geol. Soc. Am., 145:337372 .

Heinrich, H., 1988. Origin and consequences of cyclic ice rafting in the northeast Atlantic Ocean during the past 130,000 years. Quat. Res., 29:142-152.

Henshaw, P. C., and Merrill, R. T., 1980. Magnetic and chemical changes in marine sediments. Rev. Geophys. Space Phys., 18:483-504.

Imbrie, J., 1985. A theoretical framework for the Pleistocene ice ages. $J$. Geol. Soc. (London), 142:417-432.

Imbrie, J., Hays, J. D., Martinson, D. G., McIntyre, A., Mix, A. C., Morley, J. J., Pisias, N. G., Prell, W. L., and Shackleton, N. J., 1984. The orbital theory of Pleistocene climate: support from a revised chronology of the marine $\delta^{18} \mathrm{O}$ record. In Berger, A. L., Imbrie, J., Hays, J., Kukla, G., and Saltzman, B. (Eds.), Milankovitch and Climate (Pt. 1): Dordrecht, The Netherlands (D. Reidel), 269305.

Imbrie, J., and Imbrie, J. Z., 1980. Modelling the climatic response to orbital variations. Science, 207:943-953.

Jenkins, D. G., Bowen, D. Q., Adams, C. G., Shackleton, N. J., and Brassell, S. C., 1985. The Neogene: Part 1. In Snelling, N. J. (Ed.), The Chronology of the Geological Record. Mem. Geol. Soc. (London), 10:199-210.

Jenkins, G. M., and Watts, D. G., 1968. Spectral Analysis and Its Applications: San Francisco (Holden Day),

Karlin, R., and Levi, S., 1983. Diagenesis of magnetic minerals in recent hemipelagic sediments. Nature, 303:327-330.

1985. Geochemical and sedimentological control of the magnetic properties of hemipelagic sediments. J. Geophys. Res., 90: 10,373-10,392.

Karlin, G. M., Lyle, M., and Heath, G. R., 1987. Authigenic magnetite formation in suboxic marine sediments. Nature, 326:490-493.

Kennett, J. P., 1981. Marine tephrochronology. In Emiliani, C. (Ed.), The Sea (Vol. 7): The Oceanic Lithosphere: New York (Wiley-Interscience), 1373-1436.

Kent, D. V., 1982. Apparent correlation of paleomagnetic intensity and climatic records in deep-sea sediments. Nature, 299:538.

Kidd, R. B., Searle, R. C., Weaver, P.P.E., Jacobs, C. L., Huggett, Q. J., Noel, M. J., and Schultheiss, P. J., 1983. King's Trough Flank: geological and geophysical investigations of its suitability for highlevel radioactive waste disposal. Inst. Oceanogr. Sci. Rep., No. 166.

Kirschvink, J. L., and Lowenstam, H. A., 1979. Mineralization and magnetization of Chiton teeth: palaeomagnetic, sedimentologic and biologic implications of organic magnetite. Earth Planet. Sci. Lett., 44:193-204.

Kobayashi, K., and Nomura, M., 1974. Ferromagnetic minerals in the sediment cores collected from the Pacific basin. J. Geophys. Res., 40:501-512.

Kolla, V., Henderson, L., and Biscaye, P. E., 1976. Clay mineralogy and sedimentation in the western Indian Ocean. Deep-Sea Res., 23: 949-961.

Lancaster, D. E., 1966. Electronic metal detection. Electronics World (Dec.), 39-62.

Lowrie, W., and Heller, F., 1982. Magnetic properties of marine limestones. Rev. Geophys. Space Phys., 20:171-192.

Lyle, M., 1983. The brown-green colour transition in marine sediments: a marker of the FeIII-FeII redox boundary. Limnol. Oceanogr., 28: 1026-1033.

Mascle, A., Moore, J. C., et al., 1988. Proc. ODP, Init. Repts., 110: College Station TX (Ocean Drilling Program).

Mead, G. A., Tauxe, L., and LaBrecque, J. L., 1986. Oligocene paleoceanography of the South Atlantic: paleoclimatic implications of sediment accumulation rates and magnetic susceptibility measurements. Paleoceanography, 1:273-284.

Molyneux, L., and Thompson, R., 1973. Rapid measurement of the magnetic susceptibility of long cores of sediment. Geophys. J. R. Astron. Soc., 32:479-481. 
Morley, J. J., and Hays, J. D., 1978. Spectral analysis of climatic records from the subtropical South Atlantic. Geol. Soc. Am., Abstr. Programs, 10:460.

Murray, J. W., 1979. Iron oxides. In Burns, R. G. (Ed.), Marine Minerals: Reviews in Mineralogy. Mineral. Soc. Am. Publ., 6:47-98.

Nesteroff, W. D., 1982. The origin of the ferromanganese coatings of deep-sea rocks in the Atlantic Ocean. In Scrutton, R. A., and Tulwain, M. (Eds.), The Ocean Floor: New York (Wiley and Sons), 129-146.

Olausson, E., 1967. Climatological, geoeconomical, and paleoceanographical aspects of carbonate deposition. Prog. Oceanogr., 4:245265.

Oldfield, F., Dearing, J. A., Thompson, R., and Garret-Jones, S. E., 1978. Some magnetic properties of lake sediments and their possible links with erosion rates. Polskie Archive. Hydrobiologia, 25:321331.

Oldfield, F., and Robinson, S. G., 1985. Geomagnetism and palaeoclimate. In Tooley, M. J., and Sheail, G. M. (Eds), The Climatic Scene: London (Allen and Unwin), 186-205.

Peterson, L. C., and Prell, W. L., 1985a. Carbonate dissolution in recent sediments of the eastern equatorial Indian Ocean: preservation patterns and carbonate loss above the lysocline. Mar. Geol., 64:259290.

1985b. Carbonate preservation and rates of climatic change: an $800 \mathrm{kyr}$ record from the Indian Ocean. In Sundquist, E. T., and Broecker, W. S. (Eds.), The Carbon Cycle and Atmospheric $\mathrm{CO}_{2}$ : Natural Variations Archean to Present. Am. Geophys. Union Monogr., 32:251-269.

Petersen, N., von Dobeneck, T., and Vali, H., 1986. Fossil bacterial magnetite in deep-sea sediments from the South Atlantic Ocean. $\mathrm{Na}$ ture, 320:611-615.

Pisias, N. G., and Moore, T. C., Jr., 1981. The evolution of Pleistocene climate: a time series approach. Earth Planet. Sci. Lett., 52:450458.

Prell, W. L., 1984. Monsoonal climate of the Arabian Sea during the late Quaternary: a response to changing solar radiation. In Berger, A. L., Imbrie, J., Hays, J., Kukla, G., and Saltzman, B. (Eds.), Milankovitch and Climate (Pt. 1): Dordrecht, The Netherlands (D. Reidel), 349-366.

Prell, W. L., Imbrie, J., Martinson, D. G., Morley, J. J., Pisias, N. G., Shackleton, N. J., and Streeter, H. F., 1986. Graphic correlation of oxygen isotope stratigraphy: application to the late Quaternary. $\mathrm{Pa}$ leoceanography, 1:137-162.

Prell, W. L., Niitsuma, N., et al., 1989. Proc. ODP, Init. Repts., 117: College Station, TX (Ocean Drilling Program).

Radhakrishnamurty, C., Likhite, S. D., Amin, B. S., and Somayajulu, B.L.K., 1968. Magnetic susceptibility stratigraphy in ocean sediment cores. Earth Planet. Sci. Lett., 4:464-468.

Ramsay, A.T.S., 1974. The distribution of calcium carbonate in deepsea sediments. In Hay, W. W. (Ed.), Studies in Paleoceanography. Spec. Publ., Soc. Econ. Paleontol. Mineral., 20:58-76.

Rea, D. K., Chambers, L. W., Chuey, J. M., Janecek, T. R., Leinen, M., and Pisias, N. G., 1986. A 420,000-year record of cyclicity in oceanic and atmospheric processes from the eastern equatorial $\mathrm{Pa}$ cific. Paleoceanography, 1:577-586.

Robinson, S. G., 1982. Two applications of mineral-magnetic techniques to deep-sea sediment studies. Geophys. J. R. Astron. Soc., 69:294. 1986a. The late Pleistocene palaeoclimatic record of North Atlantic deep-sea sediments revealed by mineral-magnetic measurements. Phys. Earth Planet. Inter., 42:22-47.

1986b. Mineral magnetism of deep-sea sediments: palaeoclimatic implications [Ph.D. thesis]. Univ. Liverpool, United Kingdom.

Robinson, S. G., and Bloemendal, J., 1983. The application of mineralmagnetic measurements to deep-sea sediments: some preliminary results. Trans. Am. Geophys. Union, 64:241.

Ruddiman, W. F., Cameron, D., and Clement, B. M., 1987. Sediment disturbance and correlation of offset holes drilled with the hydraulic piston corer: Leg 94. In Ruddiman, W. F., Kidd, R. B., Thomas, E., et al., Init. Repts. DSDP, 94, Pt. 2: Washington (U.S. Govt. Printing Office), 615-634.

Ruddiman, W. F., Kidd, R. B., Thomas, E., et al., 1987. Init. Repts. DSDP, 94, Pts. 1 and 2: Washington (U.S. Govt. Printing Office).
Ruddiman, W. F., and McIntyre, A., 1976. Northeast Atlantic paleoclimatic changes over the past 600,000 years. Mem. Geol. Soc. Am., 145:111-146.

Ruddiman, W. F., and Raymo, M. E., 1988. Northern Hemisphere climate regimes during the past $3 \mathrm{Ma}$ : possible tectonic connections. Phil. Trans. R. Soc. London, Ser. B, 318:411-430.

Ruddiman, W. F., Raymo, M. E., and McIntyre, A., 1986. Matuyama 41,000-year cycles: North Atlantic Ocean and Northern Hemisphere ice sheets. Earth Planet. Sci. Lett., 80:117-129.

Ruddiman, W. F., Sarnthein, M., Baldauf, J., et al., 1988. Proc. ODP, Init. Repts., 108: College Station, TX (Ocean Drilling Program).

Sager, W. W., 1986. Magnetic susceptibility measurements of metal contaminants in ODP Leg 101 cores. In Austin, J. A., Jr., Schlager, W., Palmer, A. A., et al., Proc. ODP, Init. Repts., 101: College Station, TX (Ocean Drilling Program, 39-45.

Sclater, J. G., Abbott, D., and Thiede, J., 1977. Paleobathymetry and sediments of the Indian Ocean. In Heirtzler, J. R., Bolli, H. M., Davies, T. A., Saunders, J. B., and Sclater, J. G. (Eds.), Indian Ocean Geology and Biostratigraphy: Washington (American Geophysical Union), 25-59.

Shackleton, N. J., 1977. The oxygen isotope stratigraphic record of the late Pleistocene. Phil. Trans. R. Soc. London, Ser. B, 280:169-182.

Shaw, A. B., 1964. Time in Stratigraphy: New York (McGraw-Hill).

Sheu, D. D., and Presley, B. J., 1986. Variations of calcium carbonate, organic carbon and iron sulphides in anoxic sediment from the Orca Basin, Gulf of Mexico. Mar. Geol., 70:103-118.

Smith, G. M., and Banerjee, S. K., 1987. The dependence of weak-field susceptibility on applied magnetic field. Phys. Earth Planet. Inter., $46: 71-76$

Somayajulu, B.L.K., Radhakrishnamurty, C., and Walsh, T. J., 1974. Susceptibility as a tool for studying magnetic stratigraphy of marine sediments. Proc. Workshop Conf. on Late Cenozoic Magnetostratigraphy-Comparison With Bio-, Climato-, and Lithostratigraphic Zones, Tokyo.

Somayajulu, B.L.K., Walsh, T. J., and Radhakrishnamurty, C., 1975. Magnetic susceptibility stratigraphy of Pacific Pleistocene sediments. Nature, 253:616-617.

Srivastava, S. P., Arthur, M., Clement, B., et al., 1987. Proc. ODP, Init. Repts., 105: College Station, TX (Ocean Drilling Program).

Streeter, S. S., and Shackleton, N. J., 1979. Paleocirculation of the deep North Atlantic: 150,000 year record of benthic foraminifera and oxygen-18. Science, 203:168-171.

Thompson, J., Colley, S., Higgs, N. C., Hydes, D. J., Wilson, T.R.S., and Sorensen, J., 1987. Geochemical oxidation fronts in Northeast Atlantic distal turbidites and their effects in the sedimentary record. In Weaver, P.P.E., and Thompson, J. (Eds.), Geology and Geochemistry of Abyssal Plains. Spec. Publ., Geol. Soc. London, 31:167177.

Thompson, R., 1973. Palaeolimnology and palaeomagnetism. Nature, 242:182-184.

Thompson, R., Battarbee, R. W., O'Sullivan, P. E., and Oldfield, F., 1975. Magnetic susceptibility of lake sediments. Limnol. Oceanogr., 20:687-698.

Thompson, R., and Morton, D. J., 1979. Magnetic susceptibility and particle-size distribution in recent sediments of the Loch Lomond drainage basin, Scotland. J. Sediment. Petrol., 49:801-812.

Thompson, R., and Oldfield, F., 1986. Environmental Magnetism: London (Allen and Unwin).

van Andel, T. H., 1975. Mesozoic/Cenozoic calcite compensation depth and the global distribution of calcareous sediments. Earth Planet. Sci. Lett., 26:187-194.

Vincent, E., 1974. Cenozoic planktonic biostratigraphy and paleoceanography of the tropical western Indian Ocean. In Fisher, R. L., Bunce, E. T., et al., Init. Repts. DSDP, 24: Washington (U.S. Govt. Printing Office), 1111-1150.

1977. Indian Ocean Neogene planktonic foraminiferal biostratigraphy and its paleoceanographic implications. In Heirtzler, J. R., Bolli, H. M., Davies, T. A., Saunders, J. B., and Sclater, J. G. (Eds.), Indian Ocean Geology and Biostratigraphy: Washington (American Geophysical Union), 469-584.

Volat, J-L., Pastouret, L., and Vergnaud-Grazzini, C., 1980. Dissolution and carbonate fluctuations in Pleistocene deep-sea cores: a review. Mar. Geol., 34:1-28. 
Weaver, P.P.E., 1983. An integrated stratigraphy of the Quaternary of the King's Trough Flank area, N.E. Atlantic. Oceanol. Acta, 6:451456.

Weaver, P.P.E., and Schultheiss, P. J., 1983. Detection of repenetration and sediment disturbance in open-barrel gravity cores. J. Sediment. Petrol., 53:649-678.

Weedon, G. P., 1989. The detection and illustration of regular sedimentary cycles using Walsh power spectra and filtering, with examples from the Lias of Switzerland. J. Geol. Soc. London, 146:133-144.
Wilson, T.R.S., Thompson, J., Colley, S., Hydes, D. J., Higgs, N. C., and Sorensen, J., 1985. Early organic diagenesis: the significance of progressive subsurface oxidation fronts in pelagic sediments. Geochim. Cosmochim. Acta, 49:811-822.

Date of initial receipt: 11 July 1989

Date of acceptance: 20 December 1989

Ms 115B-198 